Prepared in cooperation with the Nevada Department of Transportation

Sediment Loads and Yield, and Selected Water-Quality Parameters in Clear Creek, Carson City and Douglas County, Nevada, Water Years 2004-07

Scientific Investigations Report 2009-5005 



\section{Sediment Loads and Yield, and Selected Water-Quality Parameters in Clear Creek, Carson City and Douglas County, Nevada, Water Years 2004-07}

By Ralph L. Seiler and James L. Wood

Prepared in cooperation with the Nevada Department of Transportation

Scientific Investigations Report 2009-5005 


\section{U.S. Department of the Interior \\ KEN SALAZAR, Secretary \\ U.S. Geological Survey \\ Suzette M. Kimball, Acting Director}

U.S. Geological Survey, Reston, Virginia: 2009

For more information on the USGS - the Federal source for science about the Earth, its natural and living resources, natural hazards, and the environment, visit http://www.usgs.gov or call 1-888-ASK-USGS

For an overview of USGS information products, including maps, imagery, and publications, visit http://www.usgs.gov/pubprod

To order this and other USGS information products, visit http://store.usgs.gov

Any use of trade, product, or firm names is for descriptive purposes only and does not imply endorsement by the U.S. Government.

Although this report is in the public domain, permission must be secured from the individual copyright owners to reproduce any copyrighted materials contained within this report.

Suggested citation:

Seiler, R.L., and Wood, J.L., 2009, Sediment loads and yield, and selected water-quality parameters in Clear Creek, Carson City and Douglas County, Nevada, Water Years 2004-07: U.S. Geological Survey Scientific Investigations Report 2009-5005, 44 p. 


\section{Contents}

Abstract
Introduction
Purpose and Scope
Previous Investigations.
Description of Study Area
Climate
Land Use and Land Cover
Roads
Geology
Soils
Streace-Water Hydrology Characteristics .




\section{Figures}

Figure 1. Map showing location of the Clear Creek drainage basin, Carson City and Douglas County, Nevada

Figure 2. Map showing generalized land use in the Clear Creek drainage basin, Carson City and Douglas County, Nevada

Figure 3. Oblique view of land use in the Clear Creek drainage basin, Carson City and Douglas County, Nevada

Figure 4. Photograph showing residential areas in the center of the Clear Creek drainage basin, Carson City, Nevada

Figure 5. Photograph showing commercial development in eastern part of the Clear Creek drainage basin, Carson City and Douglas County, Nevada

Figure 6. Photographs showing erosion associated with U.S. Highway 50, Carson City, Nevada

Figure 7. Photograph showing unpaved residential driveway off Old Clear Creek Road, Carson City, Nevada

Figure 8. Map showing generalized geology in the Clear Creek drainage basin, Carson City and Douglas County, Nevada

Figure 9. Map showing generalized soils in the study area, Carson City and Douglas County, Nevada....

Figure 10. Photograph showing decomposed granite is the soil parent material in most of the Clear Creek drainage basin, Carson City and Douglas County, Nevada

Figure 11. Profile of the main channel of Clear Creek, Carson City and Douglas County, Nevada

Figure 12. Graphs showing annual mean discharge and monthly mean discharge at site 2, Clear Creek near Carson City (10310500), Douglas County, Nevada ....

Figure 13. Graph showing peak annual discharge at site 2, Clear Creek near Carson City (10310500), Douglas County, Nevada

Figure 14. Photograph showing view looking upstream at site 1, Clear Creek above Highway 50, near Spooner Summit (10310485), Carson City, Nevada

Figure 15. Photograph showing view looking upstream at site 2, Clear Creek near Carson City (10310500), Douglas County, Nevada ....

Figure 16. Photograph showing view looking downstream at site 3, Clear Creek at Fuji Park, at Carson City (103100518), Carson City, Nevada

Figure 17. Graphs showing dates and types of samples collected and daily mean discharge during water years 2004-07 at site 2, Clear Creek near Carson City (10310500), Douglas County, Nevada

Figure 18. Photographs showing view of weir during baseflow and storm runoff at site 2, Clear Creek near Carson City (10310500), Douglas County, Nevada

Figure 19. Graphs showing comparison of discharge, suspended-sediment concentrations, and loads at three sampling sites along Clear Creek, Carson City and Douglas County, Nevada 


\section{Figures-Continued}

Figure 20. Graphs showing relation between suspended-sediment transport rate and instantaneous discharge for three sampling sites along Clear Creek, Carson City

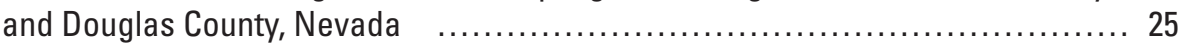

Figure 21. Graph showing particle-size distribution of bedload and suspended sediment for site 2, Clear Creek near Carson City (10310500), Douglas County, Nevada ..... 26

Figure 22. Graph showing relation between bedload transport rate and instantaneous discharge for site 2, Clear Creek near Carson City (10310500), Douglas County, Nevada.

Figure 23. Graphs showing relation between suspended-sediment transport rate and turbidity for three sampling sites along Clear Creek, Carson City and Douglas County, Nevada .....

Figure 24. Graph showing seasonal distribution in concentrations of chloride and calcium at site 2, Clear Creek near Carson City (10310500), Douglas County, Nevada

Figure 25. Graphs showing relation between suspended-sediment transport rate and instantaneous discharge for three nearby streams in the adjacent Lake Tahoe basin, Nevada

Figure 26. Graph showing relation between suspended-sediment transport rate and discharge during water years 1973-75 and 2004-07 at site 3, Clear Creek at

Fuji Park, at Carson City, Douglas County, Nevada

Figure 27. Graph showing relation between mean annual discharge and total sediment discharge for Clear Creek, Nevada

\section{Tables}

Table 1. Coefficients and bias-correction factors for regression analysis of suspendedsediment and bedload-transport rates for sampling sites along Clear Creek, Carson City and Douglas Counties, Nevada

Table 2. Estimated seasonal and annual suspended-sediment loads and average annual bedload and suspended-sediment yield for site 2, Clear Creek near Carson City (10310500), Douglas County, Nevada

Table 3. Comparison of suspended-sediment yield for Clear Creek and three nearby streams in the adjacent Lake Tahoe basin, Nevada

Table 4. Mean annual discharge and suspended- and total-sediment loads and yields for Clear Creek, Carson City and Douglas Counties, Nevada, water years 1976-77 


\section{Conversion Factors, Datums, and Definitions}

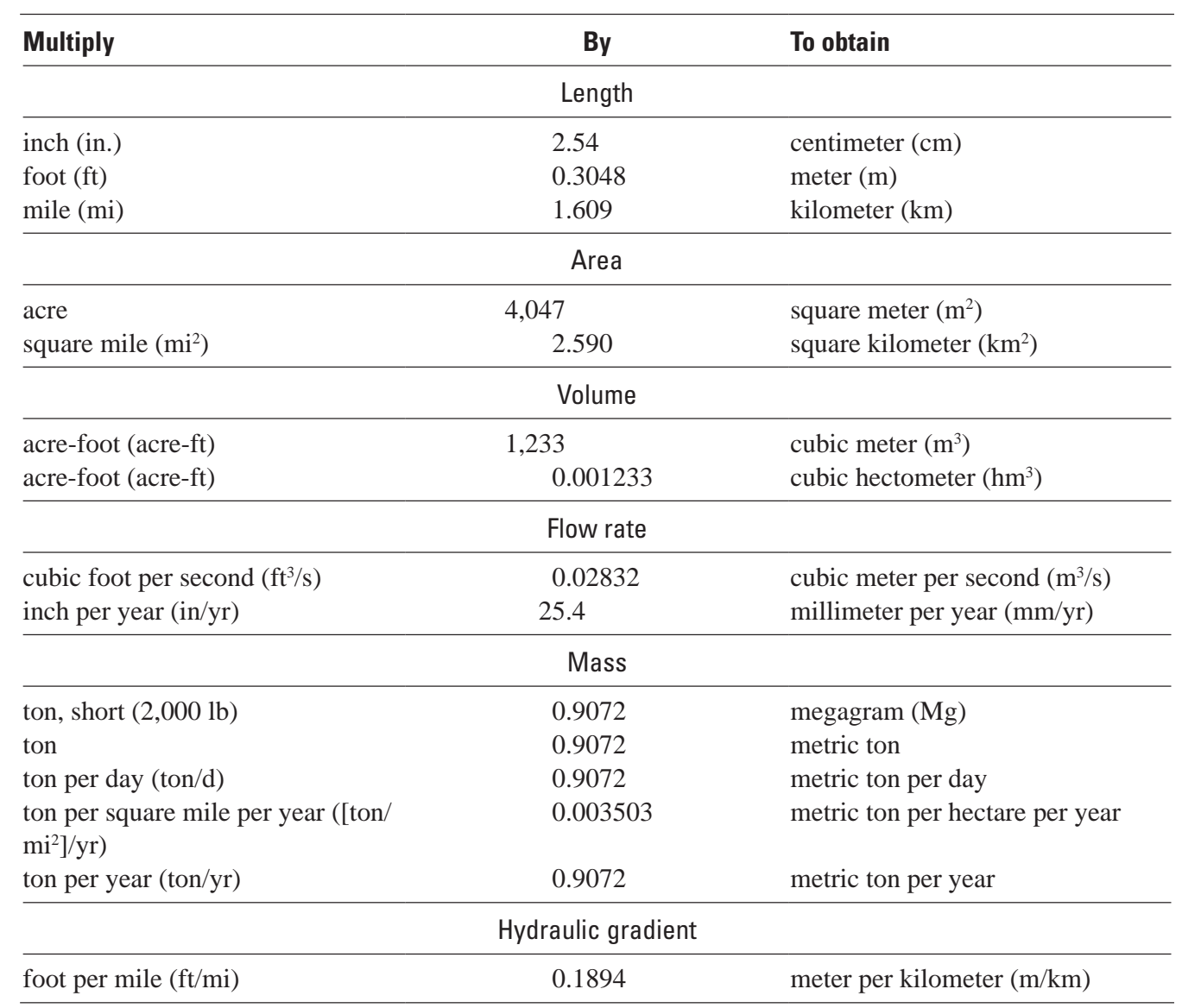

Temperature in degrees Celsius $\left({ }^{\circ} \mathrm{C}\right)$ may be converted to degrees Fahrenheit $\left({ }^{\circ} \mathrm{F}\right)$ as follows:

$$
{ }^{\circ} \mathrm{F}=\left(1.8 x^{\circ} \mathrm{C}\right)+32 \text {. }
$$

Temperature in degrees Fahrenheit $\left({ }^{\circ} \mathrm{F}\right)$ may be converted to degrees Celsius $\left({ }^{\circ} \mathrm{C}\right)$ as follows:

$$
{ }^{\circ} \mathrm{C}=\left({ }^{\circ} \mathrm{F}-32\right) / 1.8 \text {. }
$$

Specific conductance is given in microsiemens per centimeter at 25 degrees Celsius $\left(\mu \mathrm{S} / \mathrm{cm}\right.$ at $\left.25^{\circ} \mathrm{C}\right)$.

Concentrations of chemical constituents in water are given either in milligrams per liter ( $\mathrm{mg} / \mathrm{L}$ ) or micrograms per liter $(\mu \mathrm{g} / \mathrm{L})$. 


\section{Conversion Factors, Datums, and Definitions-Continued}

Datums

Vertical coordinate information is referenced to the North American Vertical Datum of 1988 (NAVD 88).

Horizontal coordinate information is referenced to North American Datum of 1983 (NAD 83).

Altitude, as used in this report, refers to distance above the vertical datum.

Definitions

Sediment concentration-The amount of sediment carried by a stream in a given amount of water, expressed as mass per unit volume (milligrams per liter).

Sediment load-The amount of sediment carried by a stream in a given amount of time, expressed as mass per unit time (tons per year).

Sediment transport-The movement and carrying of sediment by a stream.

Sediment transport rate-An instantaneous determination of the amount of sediment carried by a stream expressed as mass per unit time. For convenience in computations, it is reported in units of tons per day.

Sediment yield - The amount of sediment carried by a stream in a given amount of time divided by the contributing area, expressed as mass per unit area per unit time (tons per square mile per year).

Water year-The 12-month period (0ctober 1 through September 30 ) designated by the calendar year in which it ends. 
This page intentionally left blank. 


\title{
Sediment Loads and Yield, and Selected Water-Quality Parameters in Clear Creek, Carson City and Douglas County, Nevada, Water Years 2004-07
}

\author{
By Ralph L. Seiler and James L. Wood
}

\begin{abstract}
Some reaches of Clear Creek above U.S. Highway 395 have experienced severe erosion as a result of fires, extreme precipitation events, and past and current human activities in the basin. Previous evaluations of erosion in the basin have concluded that most of the sediment produced and transported in the basin was associated with U.S. Highway 50, a four-lane highway that roughly parallels Clear Creek through much of the basin. During this study (water years 2004-07), construction of roads and a large residential area and golf course in the area began and are likely to affect water quality and sediment transport in the basin. Sediment data were collected between October 2003 and September 2007 (water years 2004-07) from three sites along Clear Creek. Annual suspended-sediment load was estimated to range from 1,456 tons in water year 2006 to only 100 tons in water year 2004, which corresponds to suspended-sediment yields of 93.9 tons per square mile per year in 2006 to 6.4 tons per square mile per year in 2004. In water year 2006, the suspended-sediment load on December 31, 2005, alone exceeded the combined annual load for water years 2004, 2005, and 2007. Bedload sediment was estimated to comprise 73 percent of total sediment load in the creek. Mean annual suspended-sediment yield in Clear Creek basin was much greater than yields in the Logan House, Edgewood, and Glenbrook Creek basins in the adjacent Lake Tahoe basin. Comparison of data collected during this study with data collected by university researchers in the 1970s is inconclusive as to whether fundamental changes in basin sediment characteristics have occurred during the 30 -year period because different methods and sampling locations were used in the earlier studies.
\end{abstract}

\section{Introduction}

In much of its upper reach, Clear Creek typifies the small, clear, cool streams of the Sierra Nevada and winds through predominantly forest lands with occasional open meadow. The creek is used for recreation, small-scale irrigation, and fire suppression. Some reaches within the study area (fig. 1) have been severely eroded and the sediments have been transported and deposited downstream. The physical characteristics of Clear Creek basin, which include steep slopes, areas of thin soils, and highly weathered bedrock, are conducive to erosion and there are many instances of deep gullies and rilled slopes in the basin (Fritchel, 2003).

The erosion in the Clear Creek basin is a result of fires, past and current human activities in the basin, and extreme precipitation events. Several large fires in the basin have increased the potential for sediment transport by removing soil litter and changing the soil's physical characteristics. The worst fire in Carson City history in late September 1926, burned westward from the base of Clear Creek Canyon to near Spooner Lake (Rocha, 2005). Large wildfires in 1987 and 2003 burned hundreds of acres, mostly north of U.S. Highway 50 , and left the slopes susceptible to increased sediment runoff. Those fires came within about 1,000 ft of the creek, but did not actually burn vegetation along the creek.

Lumbering activities on the eastern slopes of the Sierra Nevada in the late 1800s denuded large areas of dense forests in the basin (Davis, 1912). Roads built to transport the lumber were cut up by the pressure of the loads and commonly were destroyed during winter rains. These $19^{\text {th }}$-century activities enormously changed sediment characteristics of the basin by removing the vegetation cover, which increased the susceptibility of the soils to rain-splash mobilization of the sediment particles, and by creating roads through the denuded areas, which provided paths for rapid and high-velocity runoff.

Other developments that have affected the hydrology and the sediment production and transport characteristics of the drainage basin include the construction of U.S. Highway 50 in 1960-61 as a four-lane highway that roughly parallels Clear Creek on the northern side through the steep mountains of the Sierra Nevada. Residential developments range from 5 -acre parcels in the center of the basin to 1-acre parcels in the southeastern part. At the downstream border of the study area, large commercial areas continue to be developed near U.S. Highway 395. Currently (2008), a large project that will include a residential community and a golf course is under development along the southern side of Clear Creek in the middle of the basin. 


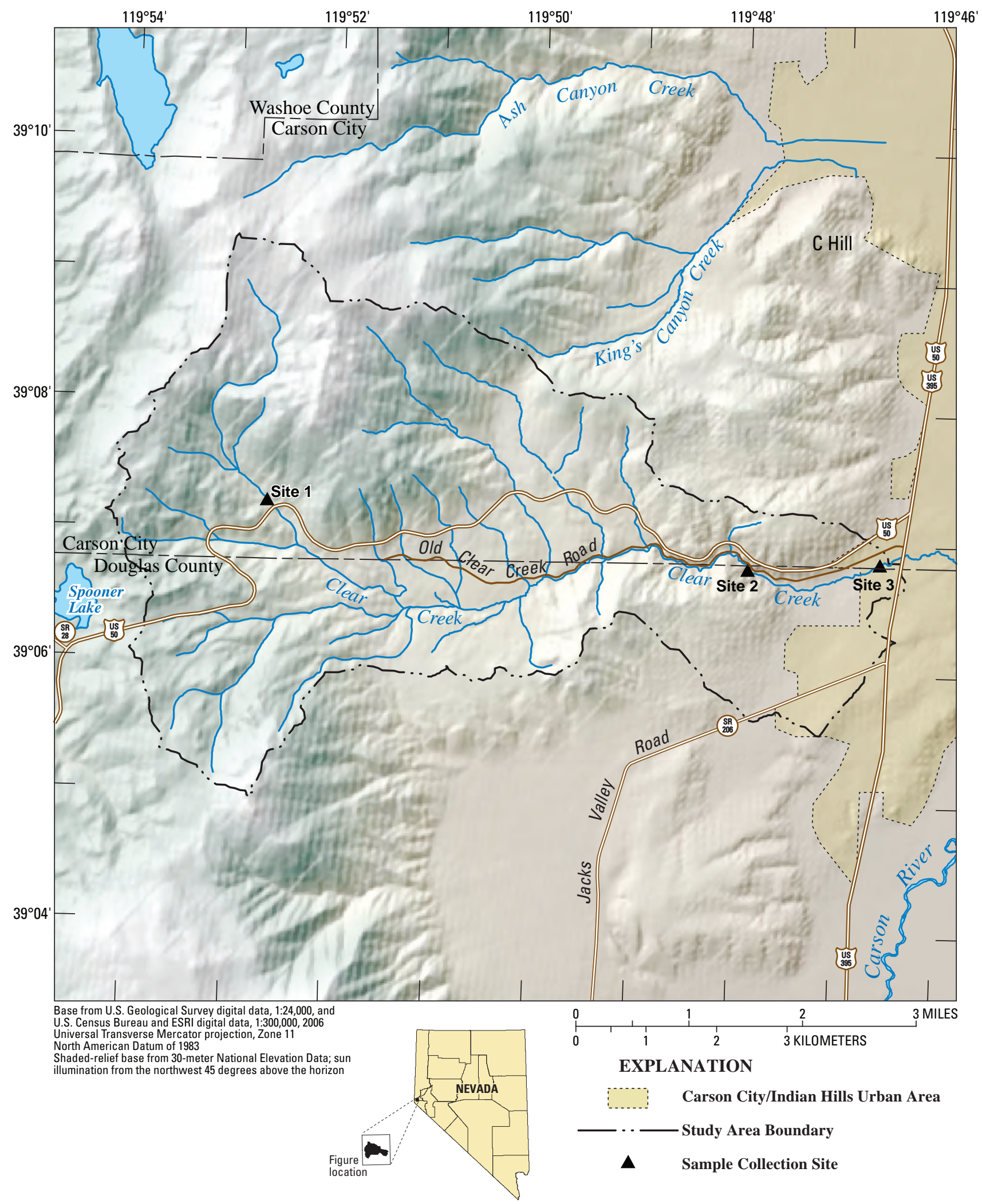

Figure 1. Location of the Clear Creek drainage basin, Carson City and Douglas County, Nevada. 
The development in the drainage basin is affecting runoff, sediment loading, and water quality to Clear Creek. Baseline data are needed to establish the basin's current sediment-transport and water-quality conditions so that the effects of ongoing development in the basin can be evaluated. To provide the data needed to establish that baseline, the U.S. Geological Survey (USGS), in cooperation with the Nevada Department of Transportation, conducted a study of sedimenttransport characteristics and water-quality conditions in the Clear Creek basin during water years 2004-07. The objectives of the study were to (1) establish baseline data for comparison with possible changes in water quality and sediment yield due to planned development; (2) quantify the relation between suspended-sediment loading and discharge in Clear Creek; and (3) use this relation to estimate sediment yield from the Clear Creek basin.

\section{Purpose and Scope}

This report documents the concentrations of suspended sediment, chemical constituents in water, streamflow, and particle-size distributions of suspended- and bed-sediment loads in the Clear Creek basin during water years 2004-07. The report also describes a simple linear regression analysis of the data and provides estimates of suspended-sediment yield in the Clear Creek basin. The study was not designed to quantify sediment yields from individual sources within the basin.

\section{Previous Investigations}

The earliest known measurements of suspended sediment and water quality from the study area were made in 1973-75 just upstream of Fuji Park by Brown and Skau (1977) as part of a regional study of water quality in streams along the east-central Sierra Nevada. Erosion and potential mitigation methods in the study area have been described in two graduate theses from the University of Nevada, Reno (Fisher, 1978; Fritchel, 2003), a Natural Resources Conservation Service report (Stevenson, 1989), and a consultant's report for Nevada Department of Transportation (PBS\&J, 2003). Fisher (1978) estimated bedload and suspended-sediment load near the USGS gaging station using a V-flume to collect and separate the sediment into bedload and suspended-sediment fractions and conducted a stream survey to identify sediment source areas. Fisher (1978) estimated that from April 1975 to September 1977, the total sediment load averaged about 1,300 ton/yr, with bedload accounting for 78 percent of total load. On the basis of data from Fisher (1978), the estimated total sediment loads for water years 1976-77 were about 1,280 and 1,130 tons, respectively, and the suspended-sediment loads for those years were 350 and 89 tons, respectively.
Stevenson (1989) concluded that severe erosion in the Clear Creek basin appeared to be primarily the result of road construction, and documented moderate to very severe bank and gully erosion associated with road banks along U.S. Highway 50 and Old Clear Creek Road. Using the Pacific Southwest Inter-Agency Committee (1968) method, Stevenson (1989) estimated that the total sediment delivered from the drainage basin to Clear Creek and U.S. Highway 395 was about 18,200 ton/yr. Stevenson (1989) concluded that 72 percent of the sediment was from erosion associated with U.S. Highway 50 and that 16 percent was from erosion associated with other roads in the basin.

PBS\&J (2003) located and evaluated sources of erosion throughout the drainage basin. They concluded that most of the sediment deposition in the basin occurred upstream of Fuji Park and that, except during major flood events, little if any sediment from the Clear Creek basin reached the Carson River. Along the main channel upstream of site 2, approximately $1,800 \mathrm{ft}$ of eroding banks were identified. PBS\&J (2003) identified major erosion areas downgradient of U.S. Highway 50, which they concluded may not have been present in 1978 because these erosion areas were not identified by Fisher (1978).

\section{Description of Study Area}

The Clear Creek study area covers an area of $17.94 \mathrm{mi}^{2}$ and ranges in altitude from 8,500 ft in the headwaters to 4,765 ft where Clear Creek leaves Fuji Park just east of U.S. Highway 395. Clear Creek originates on the eastern slopes of the Sierra Nevada in Nevada (fig. 1) and flows to its confluence with the Carson River in southern Carson City. The drainage basin is within Eagle Valley in Carson City and Douglas County, Nevada, and is adjacent to Carson Valley to the south.

\section{Climate}

The study area lies in the rain shadow of the Sierra Nevada. Precipitation falls primarily as winter snow. On the basis of data from the two nearest weather stations, the precipitation in November, December, January, and February provides about 60 percent of the total annual precipitation (10.43 in.) at the Carson City weather station and 73 percent of the total annual precipitation (22.36 in.) at the Daggett Pass station (Western Regional Climate Center, 2008). Maurer and Halford (2004) mapped precipitation in the area just south of Clear Creek as ranging from 10 to about $30 \mathrm{in} / \mathrm{yr}$.

Summers in the upland parts of the study area are cooler than on the valley floor. Mean annual temperature at the town of Carson City, altitude $4,650 \mathrm{ft}$, is $10.2^{\circ} \mathrm{C}$, and mean monthly 
temperatures range from $0.7^{\circ} \mathrm{C}$ in January to $21.1^{\circ} \mathrm{C}$ in July (period of record July 1948 to June 2007; Western Regional Climate Center, 2008). Mean annual temperature about $8 \mathrm{mi}$ south of the study area at Daggett Pass, altitude 7,330 ft, is $6.2^{\circ} \mathrm{C}$, and mean monthly temperatures range from $-1.7^{\circ} \mathrm{C}$ in December to $16.2^{\circ} \mathrm{C}$ in July (period of record December 1988 to June 2007; Western Regional Climate Center, 2008).

\section{Land Use and Land Cover}

Land-use data presented here (fig. 2) represents conditions in 2003 (U.S. Geological Survey, 2003), but considerable commercial development has occurred in the eastern tip of the study area between 2003 and 2008. Fisher (1978) described the vegetation in the basin by general association and major species. The study area mostly is undeveloped. Jeffrey pine and white fir associations dominate the higher and east- and north-facing slopes, but manzanita and sagebrush associations prevail on south-facing slopes and at lower altitudes. These plant communities cover 89 percent of the basin. The largest developed parts of the study area at present (2008) are the Indian Hills residential area in the east (1-acre of smaller lots) and low-density (5-acre or larger lots) subdivisions east of the Clear Creek Youth Center in the center of the basin (figs. 3 and 4). The 2000 census indicates that about 700 people resided in this area (U.S. Census Bureau, 2008). Access roads are under construction (2008) for a large, 1,576-acre residential development with a golf course, and 384 homes and time-share residences are in the center of the basin extending from the south side of Clear Creek to the top of the southern drainage divide. Considerable commercial development has occurred just west of U.S. Highway 395 in the past 10 years (figs. 3 and $\underline{5}$ ). Several large retail stores have been built on either side of Clear Creek, and a casino was constructed in 2007 on U.S. Highway 395 a few hundred feet north of the creek.

\section{Roads}

Roads disrupt the natural flow of surface water and are major contributors to the acceleration of erosion processes because of exposed soils on roadsides and unpaved road surfaces (Forman, 2003). The construction of U.S. Highway 50 during 1960-61 as a four-lane highway through the steep mountains of the Sierra Nevada has significantly affected erosion in the Clear Creek drainage basin (ig. 6 ). U.S. Highway 50 crosses Clear Creek in its headwaters areas and then roughly parallels the creek on the north it as it descends through steep mountains from Lake Tahoe to Carson City (fig. 1). Large road cuts and embankments made during construction of the highway form steep slopes that are susceptible to rill erosion and landslides. Culverts have been installed to collect runoff from the road surface and from natural areas upslope of the road. Discharge of water from these culverts onto fill slopes and natural slopes has created gullies. Clogged drop inlets can result in flow overtopping the edge of the roadway and causing erosion as the water drains down the adjacent slope.

Old Clear Creek Road, the eastern portion of the old U.S. Highway 50, is paved from U.S. Highway 395 to the Clear Creek Youth Center, but is not maintained by Carson City or Douglas County. Old Clear Creek Road parallels the creek, sometimes within a few feet of the channel (fig. 1). Unpaved roads from Old Clear Creek Road lead to houses near the Clear Creek Youth Center (fig. 7). In 2007, a new interchange on U.S. Highway 50 was completed at the new Golf Course Lane, which will cross Clear Creek to provide access to the planned development area in the center of the basin.

\section{Geology}

The geology of the study area has been described by Moore (1969) and Stewart (1980). A generalized geologic map of the study area is shown in figure 8. Granitic rocks of Mesozoic age make up most of the exposed rocks and are part of the Sierra Nevada batholith (Moore, 1969). Alluvial deposits, composed of Quaternary Age deposits of clay, silt, sand, gravel, and cobbles, are derived from adjacent mountains. Alluvial deposits in the middle of the study area are in an area of active channel erosion in Clear Creek. Metamorphic rocks in the study area are predominantly volcanic rocks of Late Triassic and Early Jurassic age that were metamorphosed, partly as a result of heat from and deformation by granitic intrusion (Moore, 1969). The younger rocks exposed in the study area principally are Tertiary age andesites and related volcanic rocks (Moore, 1969).

\section{Soils}

The generalized distribution of soil types in the study area is shown in figure 9 . Soil types were grouped according to descriptions of the mapping units from U.S. Soil Conservation Service $(1979,1984)$. At the highest altitudes, no soils are present and barren rock outcrops are common on ridges and crests. Along side slopes of the ridges, soils are thin sands. In the eastern part of the study area, soils are deep sands and loams. Coarse-grained granitic rocks, the dominant rock type exposed in the study area, weather to angular coarse sand and fine gravels (fig. 10) (U.S. Soil Conservation Service, 1979). The finer grained metavolcanic and metasedimentary rocks weather to a loamy soil containing considerable amounts of gravel, cobbles, and boulders (U.S. Soil Conservation Service, 1979). In most of the study area, soils range from well drained to excessively drained; however, some small areas are poorly drained because of a high water table. 


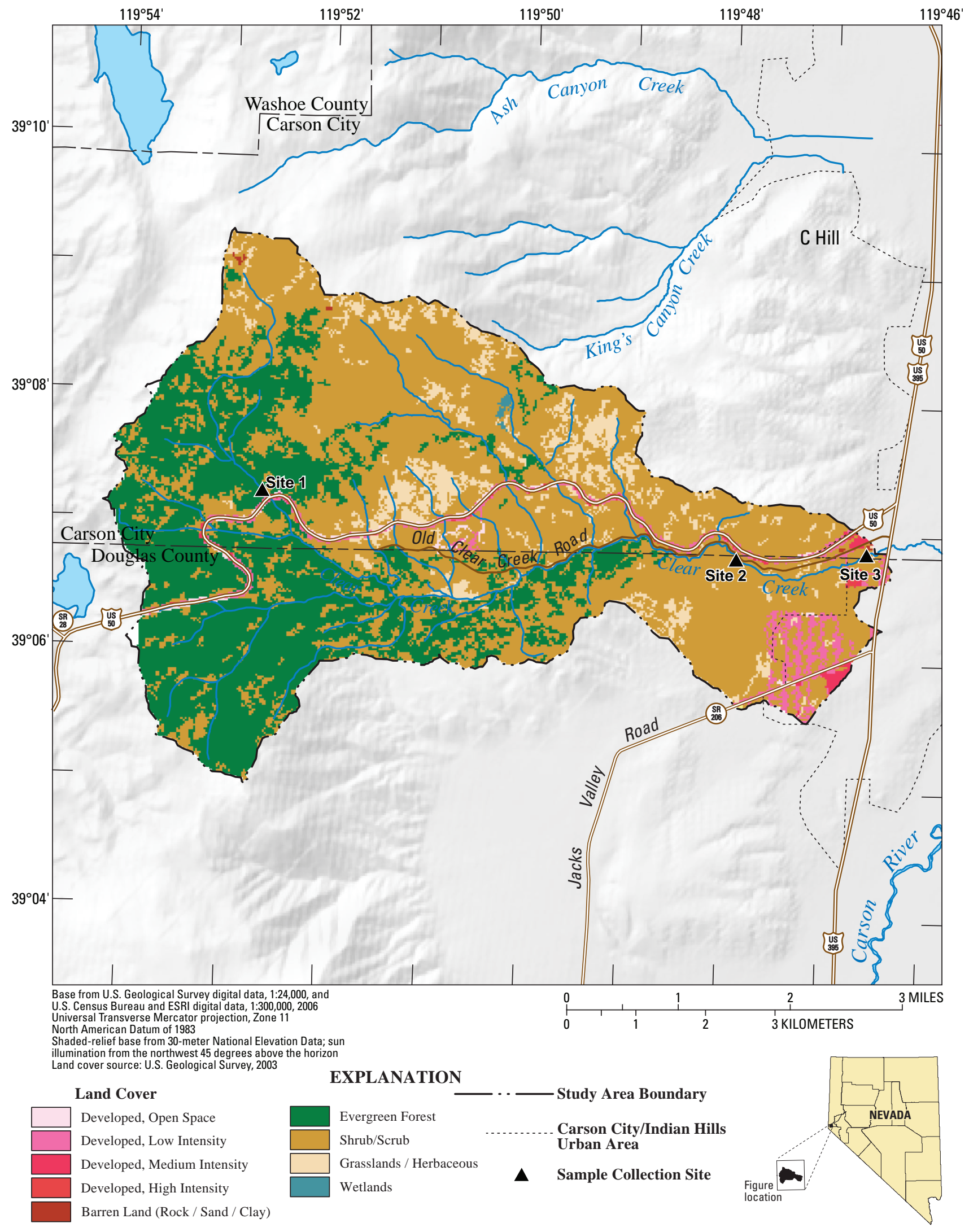

Figure 2. Generalized land use in the Clear Creek drainage basin, Carson City and Douglas County, Nevada. 


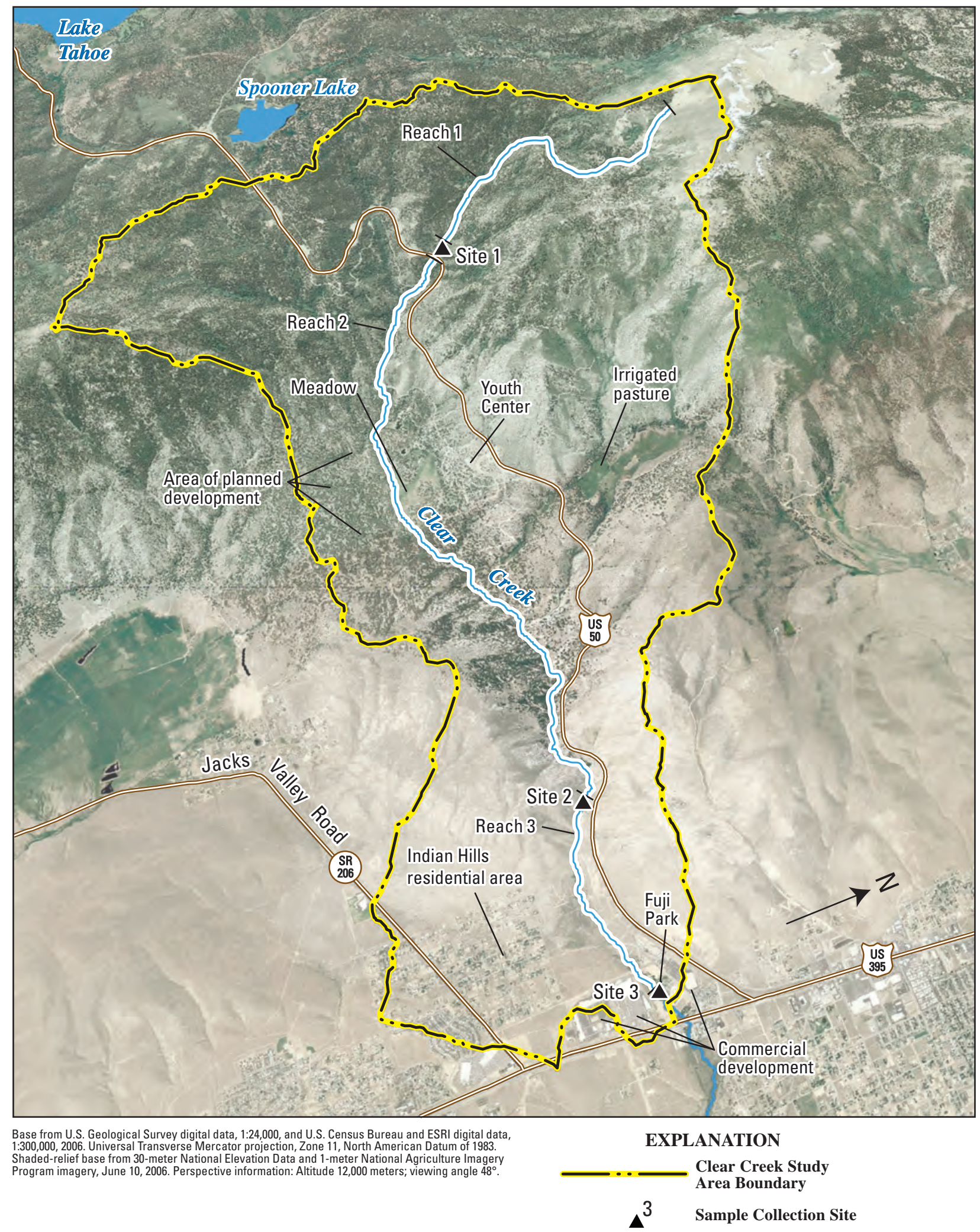

Figure 3. Oblique view of land use in the Clear Creek drainage basin, Carson City and Douglas County, Nevada. 


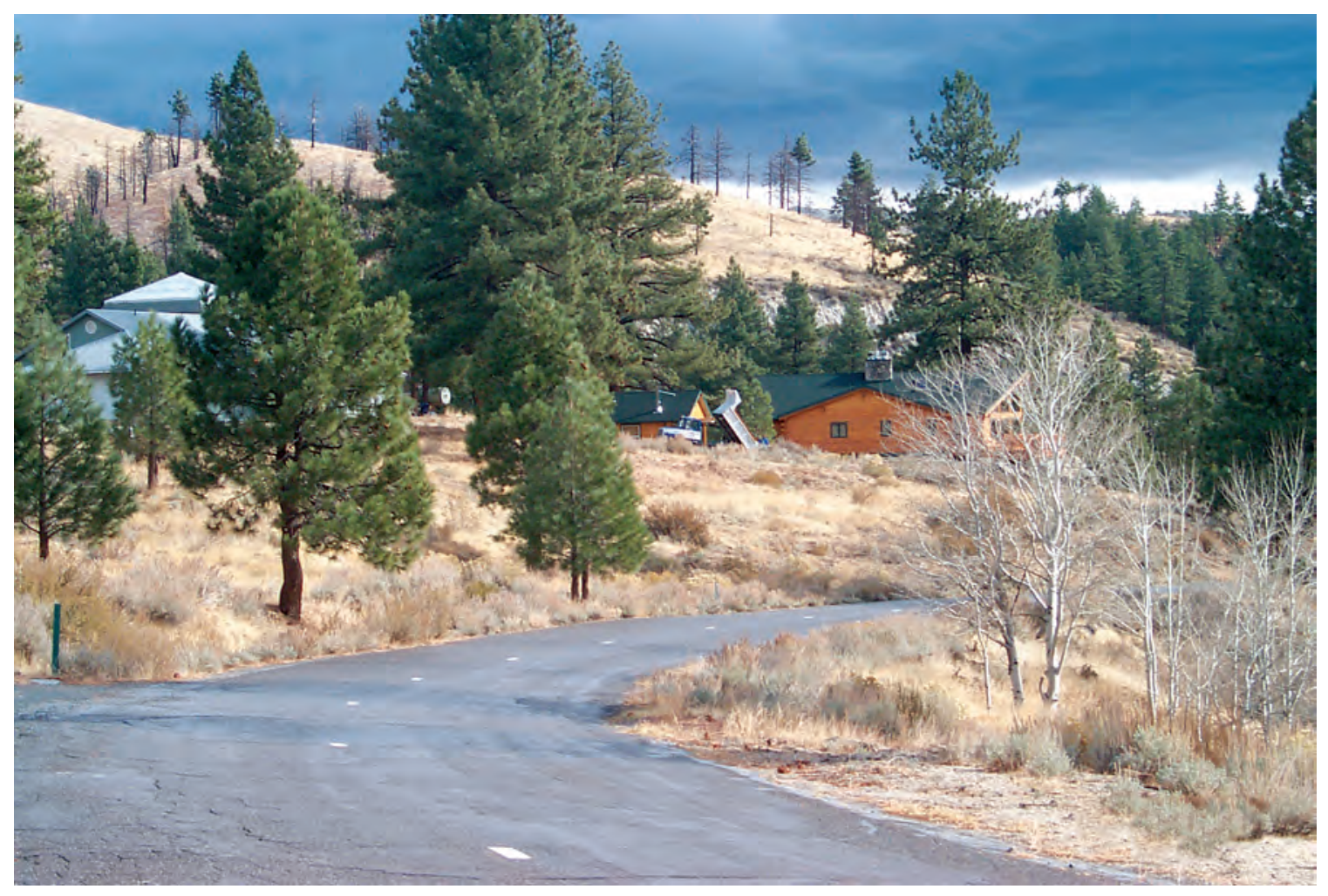

Figure 4. Residential areas in the center of the Clear Creek drainage basin, Carson City, Nevada. Photograph taken by Ralph Seiler, U.S. Geological Survey, November 13, 2006. 


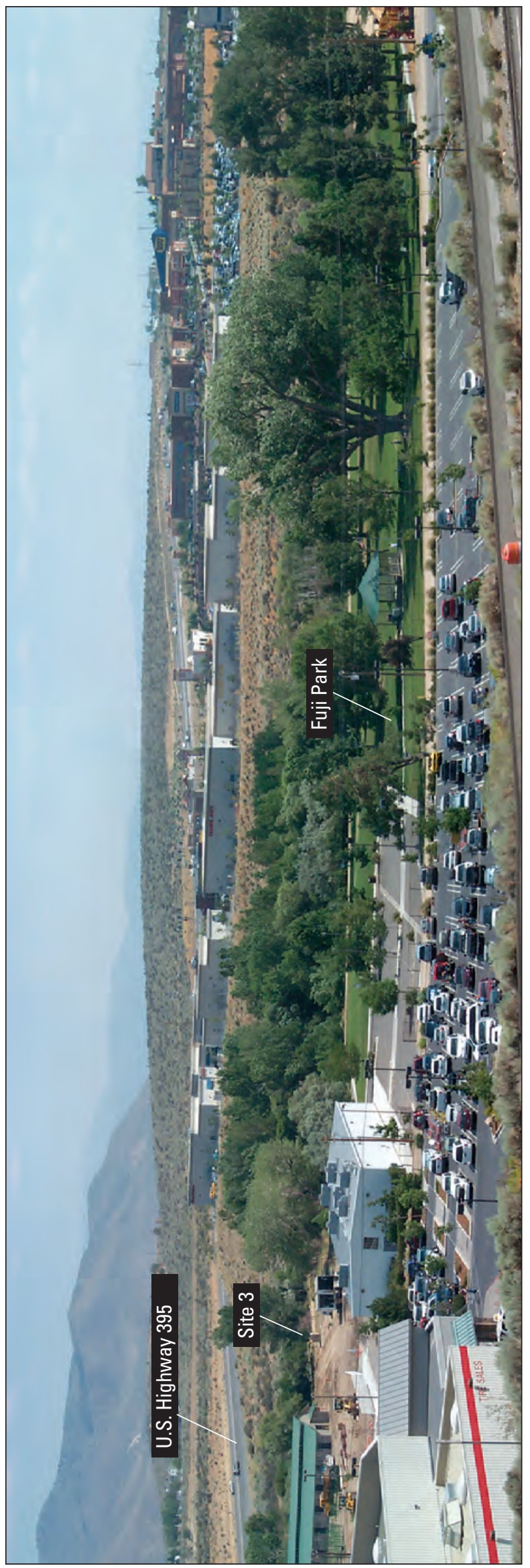

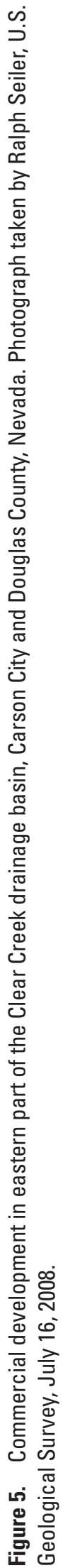




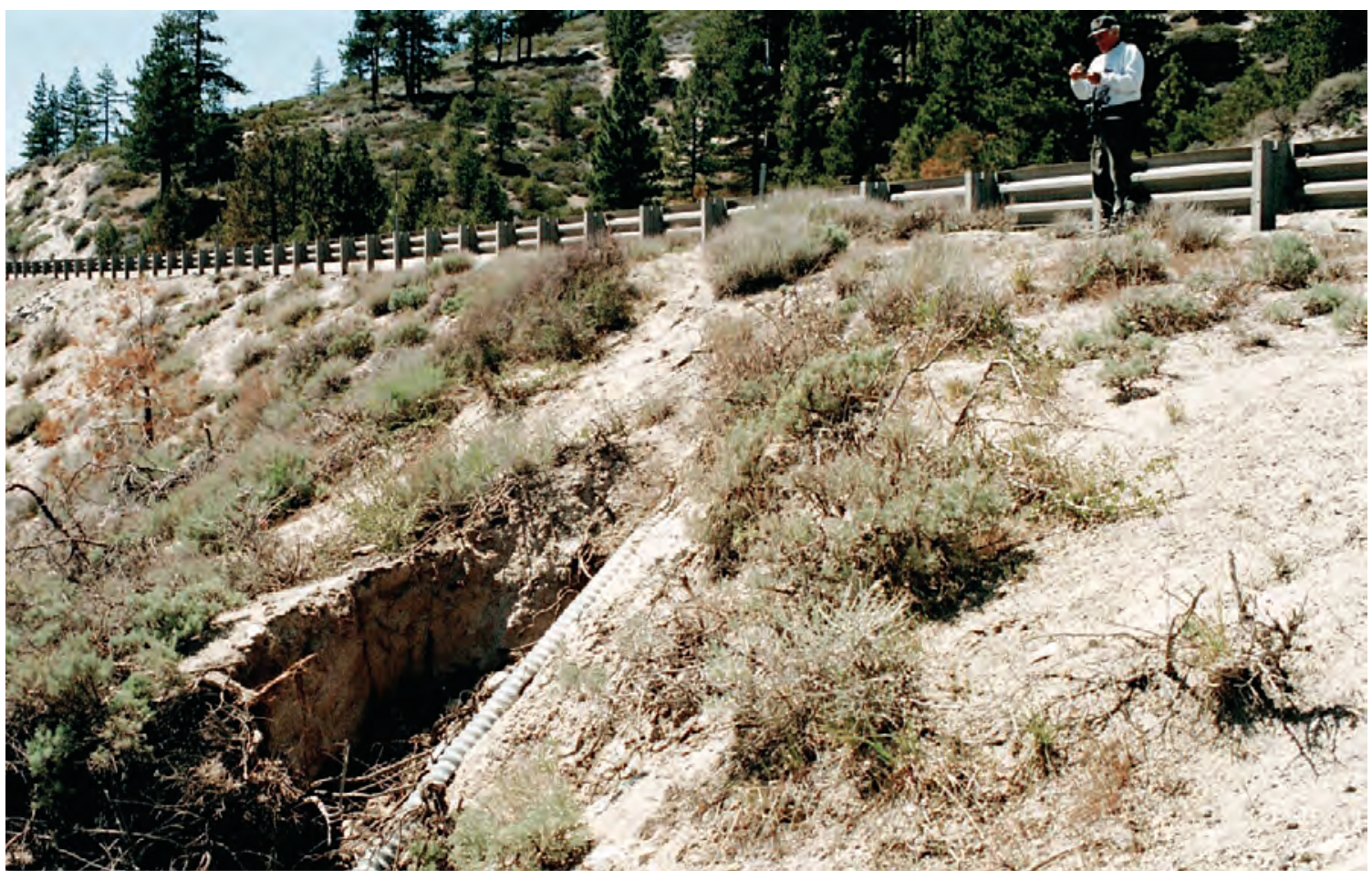

A. Gully headcut at drop culvert causing its collapse. Photograph taken by Jon Nowlin, May 2005.

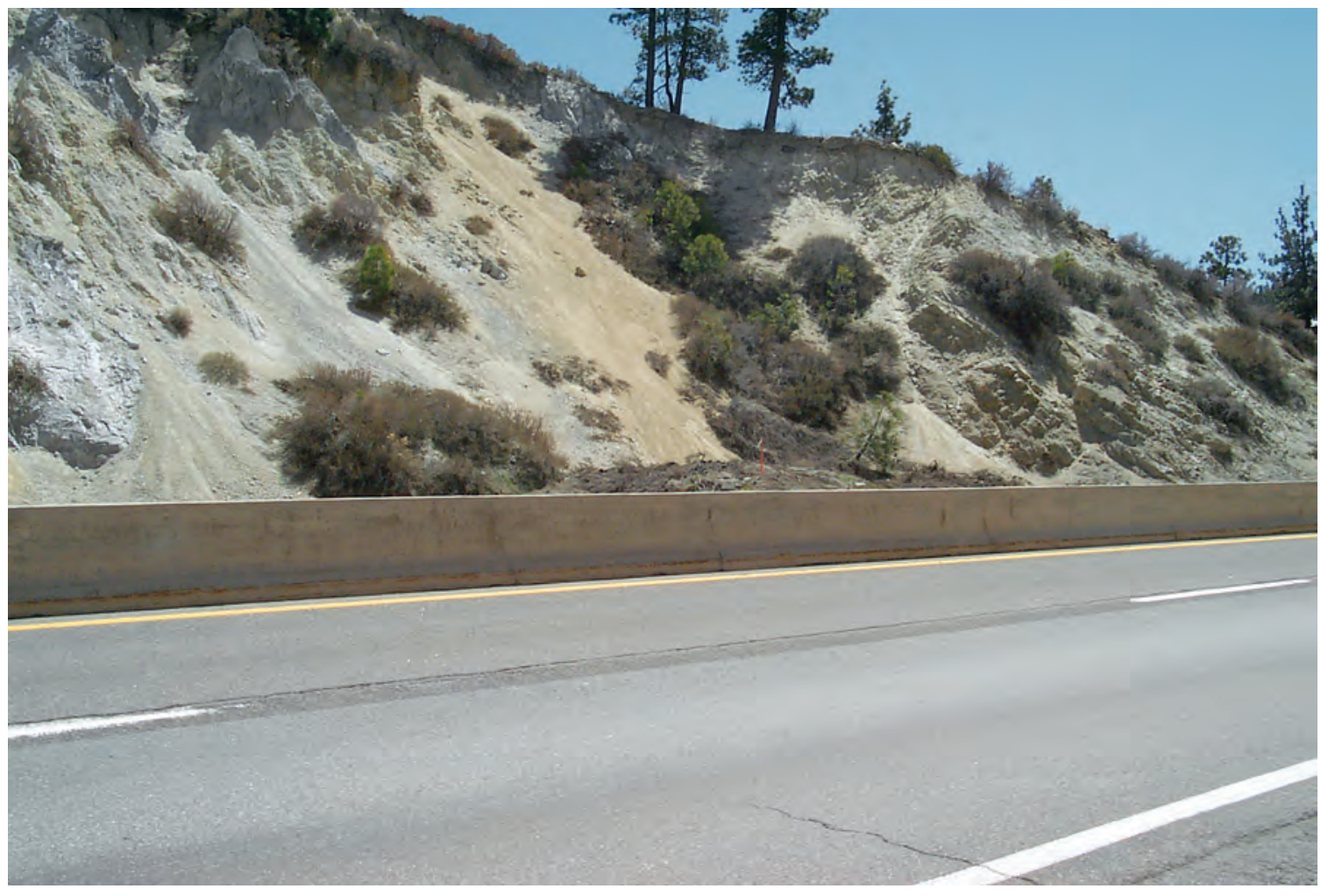

B. Land slumping along road cut. Photograph taken by Ralph Seiler, U.S. Geological Survey, April 18, 2008.

Figure 6. Erosion associated with U.S. Highway 50, Carson City, Nevada. 


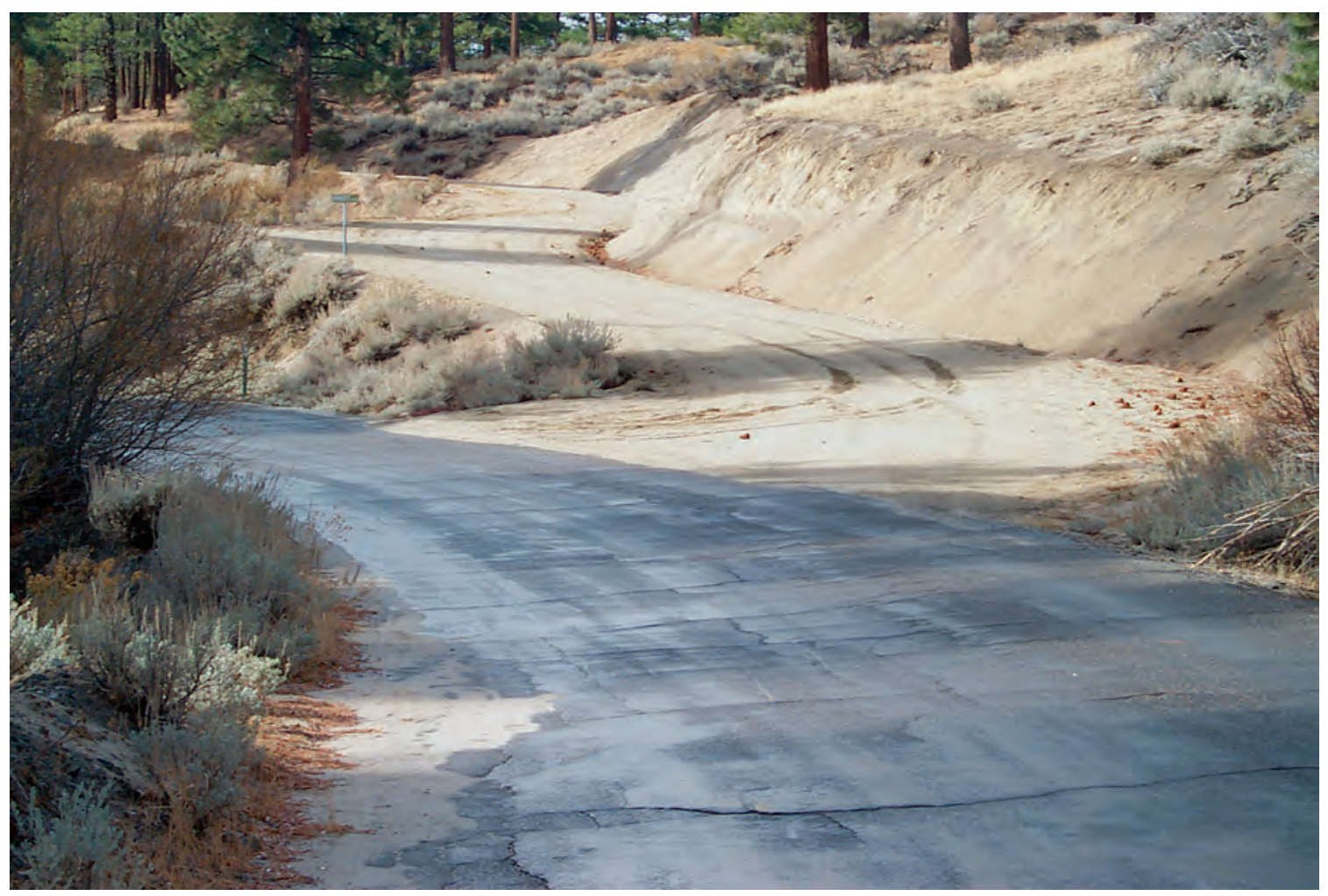

Figure 7. Unpaved residential driveway off Old Clear Creek Road, Carson City, Nevada. Photograph taken by Ralph Seiler, U.S. Geological Survey, November 13, 2006. 


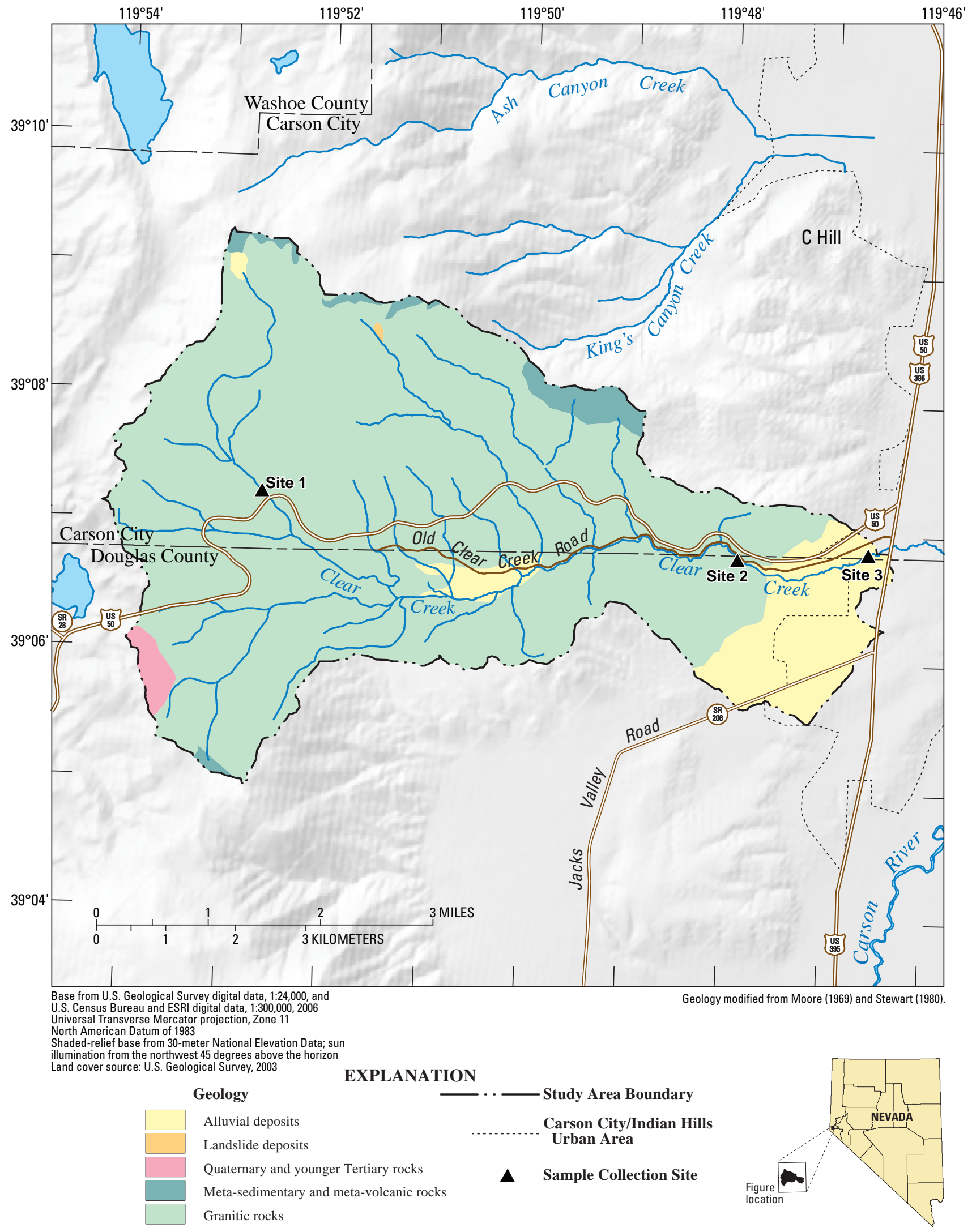

Figure 8. Generalized geology in the Clear Creek drainage basin, Carson City and Douglas County, Nevada. 


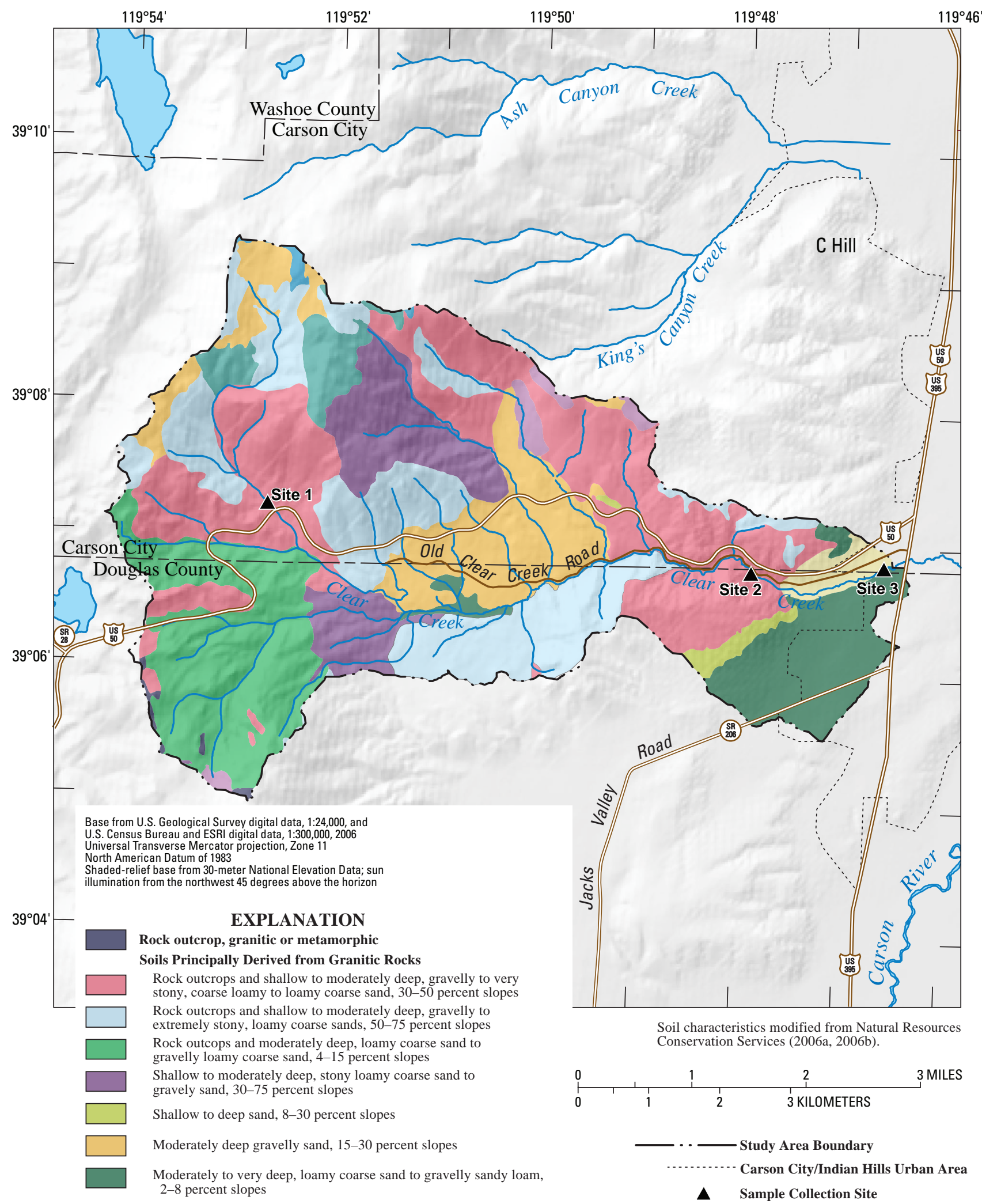

Soils Principally Derived from Metamorphic Rocks

Rock outcrops and deep, very fine sandy loams, 30-50 percent slopes

Shallow to deep, very stony loams to very fine sandy loam, 8-75 percent slopes

Soils Derived from Mixed Rocks

Deep, sandy loams to gravelly sandy loams, 0-15 percent slopes

Figure 9. Generalized soils in the study area, Carson City and Douglas County, Nevada. 


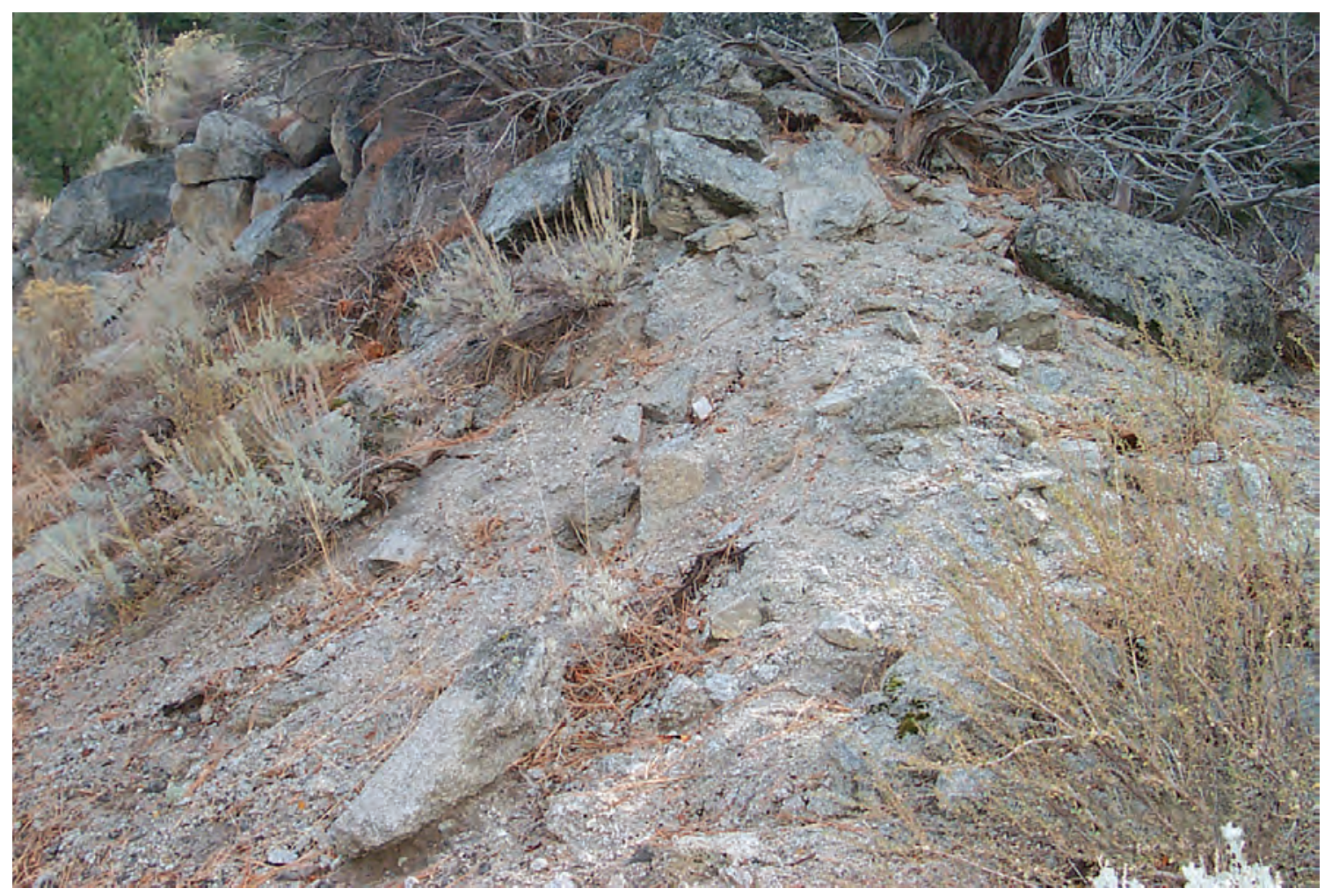

Figure 10. Decomposed granite is the soil parent material in most of the Clear Creek drainage basin, Carson City and Douglas County, Nevada. Photograph taken by Ralph Seiler, U.S. Geological Survey, November 13, 2007.

\section{Surface-Water Hydrology}

\section{Stream Characteristics}

The average slope of the main channel of Clear Creek is about $380 \mathrm{ft} / \mathrm{mi}$. The channel is steep upstream of U.S. Highway 50, but becomes nearly flat near Fuji Park and U.S. Highway 395 (fig. 11).

Most of the flow in Clear Creek originates as runoff from melting of the snowpack in the Sierra Nevada. Baseflows in the upper and middle reaches of the creek are supported by perennial springs. Storm runoff from the commercial area north of Clear Creek near U.S. Highway 395 can enter the creek from a surface ditch upstream of Fuji Park, or from a drainage pipe from a retention basin to an outfall between site 3 and U.S. Highway 395. Storm runoff from the commercial area south of Clear Creek is collected in two retention basins. Overflow from the northern basin discharges to Clear Creek upstream of Fuji Park. Overflow from the southern basin passes through a culvert under U.S. Highway 395 approximately 2,000 ft south of the main channel of Clear Creek, discharges to a ditch, and ultimately discharges into the creek east of U.S. Highway 395.

In the central part of the study area, water is diverted from Clear Creek for irrigation in the meadow south of the Clear Creek Youth Center. North of U.S. Highway 50, the water is diverted from a tributary in the center of the basin and used to irrigate a pasture for cattle grazing. A small amount of water is diverted into a 6 in. concrete pipe immediately downstream of site 2 and used for lawn irrigation at the Stewart Complex by the State of Nevada. A diversion on Clear Creek just west of U.S. Highway 395 at one time carried water to irrigate fields near Prison Farms near the Carson River, but the ditch was filled in by sediment during the December 2005 flood and was inactive through summer 2007. The channel recently has been rebuilt and now ends within Washoe Tribe of Nevada and California land east of U.S. Highway 395. 
The water now is used to promote revegetation to remediate headcutting of Clear Creek downstream of U.S. Highway 395. Downstream of site 3, the main channel of Clear Creek passes under U.S. Highway 395. Near the confluence with Carson River, Clear Creek enters an area of old oxbow features and has no clearly defined channel.

Streamflow at site 2, the USGS gaging station on Clear Creek near Carson City, varies greatly from year to year (fig. 12A). The annual mean discharge for the years of complete record (water years 1949-62, 1990-2007) is $5.5 \mathrm{ft}^{3} / \mathrm{s}$, and ranged between 2.09 and $13.4 \mathrm{ft}^{3} / \mathrm{s}$ (U.S. Geological Survey, 2008). Daily mean discharge during that period ranged from $0.42 \mathrm{ft}^{3} / \mathrm{s}$ (August 3, 1992) to $198 \mathrm{ft}^{3} / \mathrm{s}$ (January 2, 1997). About 39 percent of the annual discharge occurs during March-May, and the greatest monthly mean discharge occurs in April (fig. 12B).

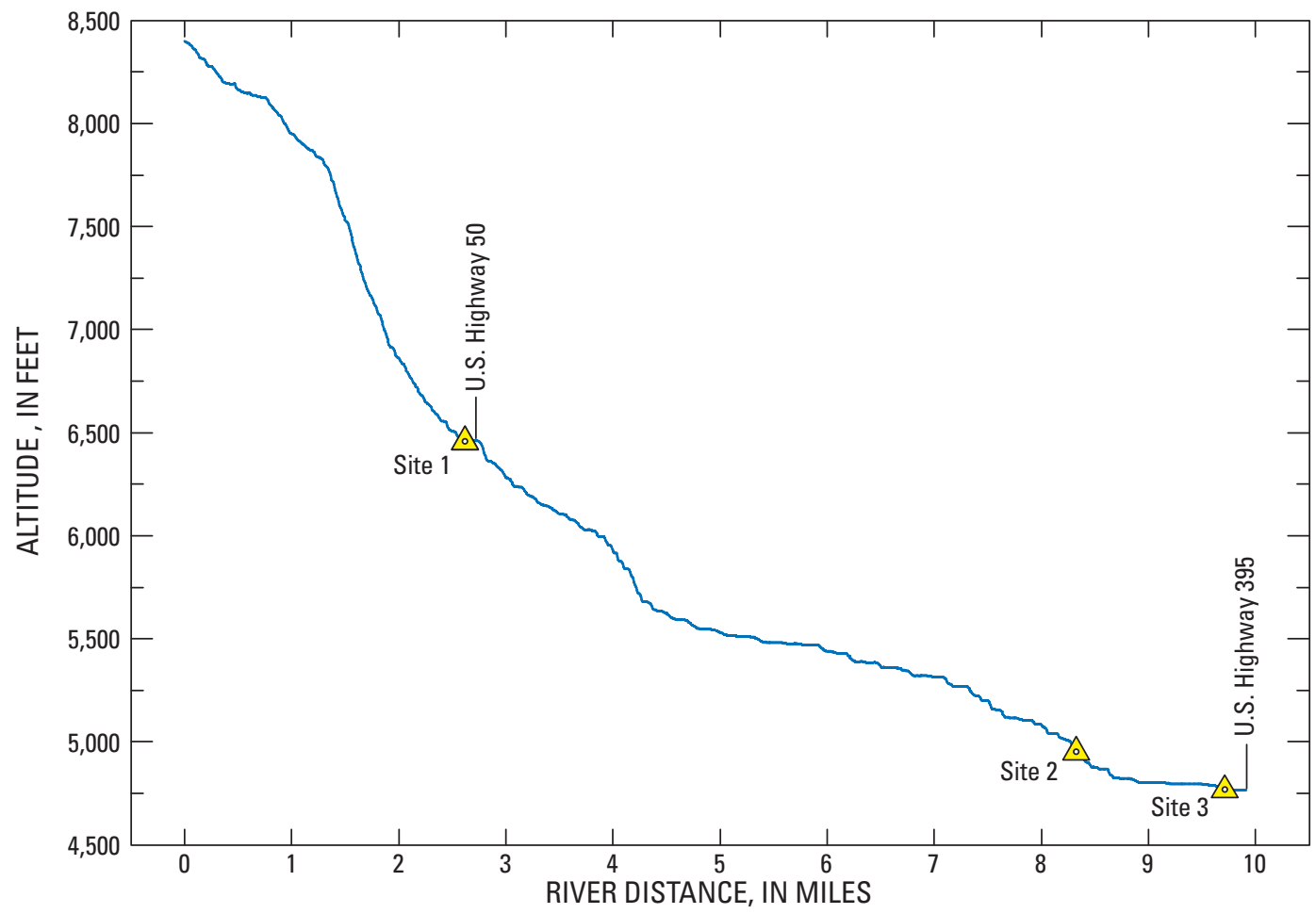

Figure 11. Profile of the main channel of Clear Creek, Carson City and Douglas County, Nevada. 

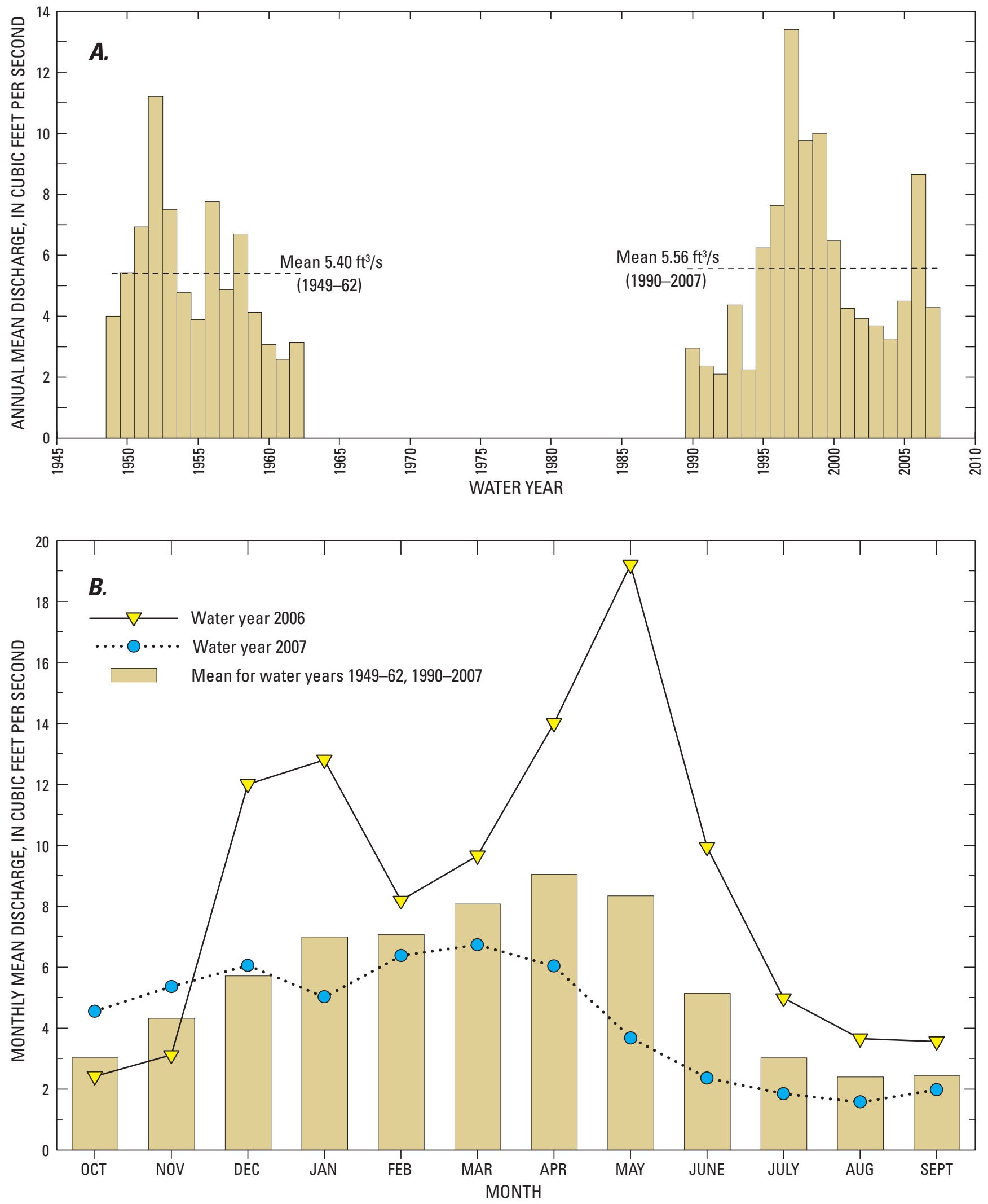

Figure 12. Annual mean discharge and monthly mean discharge at site 2, Clear Creek near Carson City (10310500), Douglas County, Nevada. 


\section{Peak Streamflow and Floods}

Peak streamflow in Clear Creek occurs during periods of snowmelt runoff in spring and rainfall on snow in winter. The peak annual discharge at site 2 for 1948-78 and 1989-2007 is shown in figure 13. Of the 50 peak discharges during these periods of record, 25 occurred from November through February, 16 from March through May, 8 are of unknown date, and 1 occurred in October. Floods also are primarily winter events, when rain falls on snow and causes rapid melting; for the 7 years in which peak discharge exceeded $100 \mathrm{ft}^{3} / \mathrm{s}$ (fig. 13), the peak discharge occurred in December in 3 years and in January in 2 years. Each of these events was associated with regional flooding near Carson City (Jeton, 2006). These winter floods typically result from "Pineapple Express" storms, which draw warm wet air from the tropics near Hawaii and bring strong winds, unusually warm temperatures, and heavy precipitation to the west coast of North America (Dettinger, 2004).
Winter and spring storms have caused major flooding in Clear Creek and nearby creeks. Eighteen of 23 major floods on the Carson River between Carson City and Dayton were attributed to "Pineapple Express" warm winter storms (Jeton, 2006). Heavy rain on snow in December 1997 resulted in a large flood that produced the largest peak discharge of record for the creek and washed out portions of Old Clear Creek Road in areas where the road closely abuts the stream. The second highest recorded peak discharge of Clear Creek also was a rain on snow event and occurred during this study. The annual peak discharge in Clear Creek never has occurred during summer for the period of record. Summer storms cause flooding less frequently, but on occasion, intense thunderstorms in the Carson City area during the summer can cause severe flooding. Although flooding in Clear Creek was not specifically mentioned, runoff from a summer thunderstorm in July 1875 inundated Carson City with waters from Kings and Ash Canyons, a few miles north of Clear Creek (Jeton, 2006). A thunderstorm in August 1958 that produced a little over an inch of water caused flash flooding off of ' $\mathrm{C}$ Hill' (fig. 1), which was barren as a result of a fire earlier that year (Jeton, 2006).

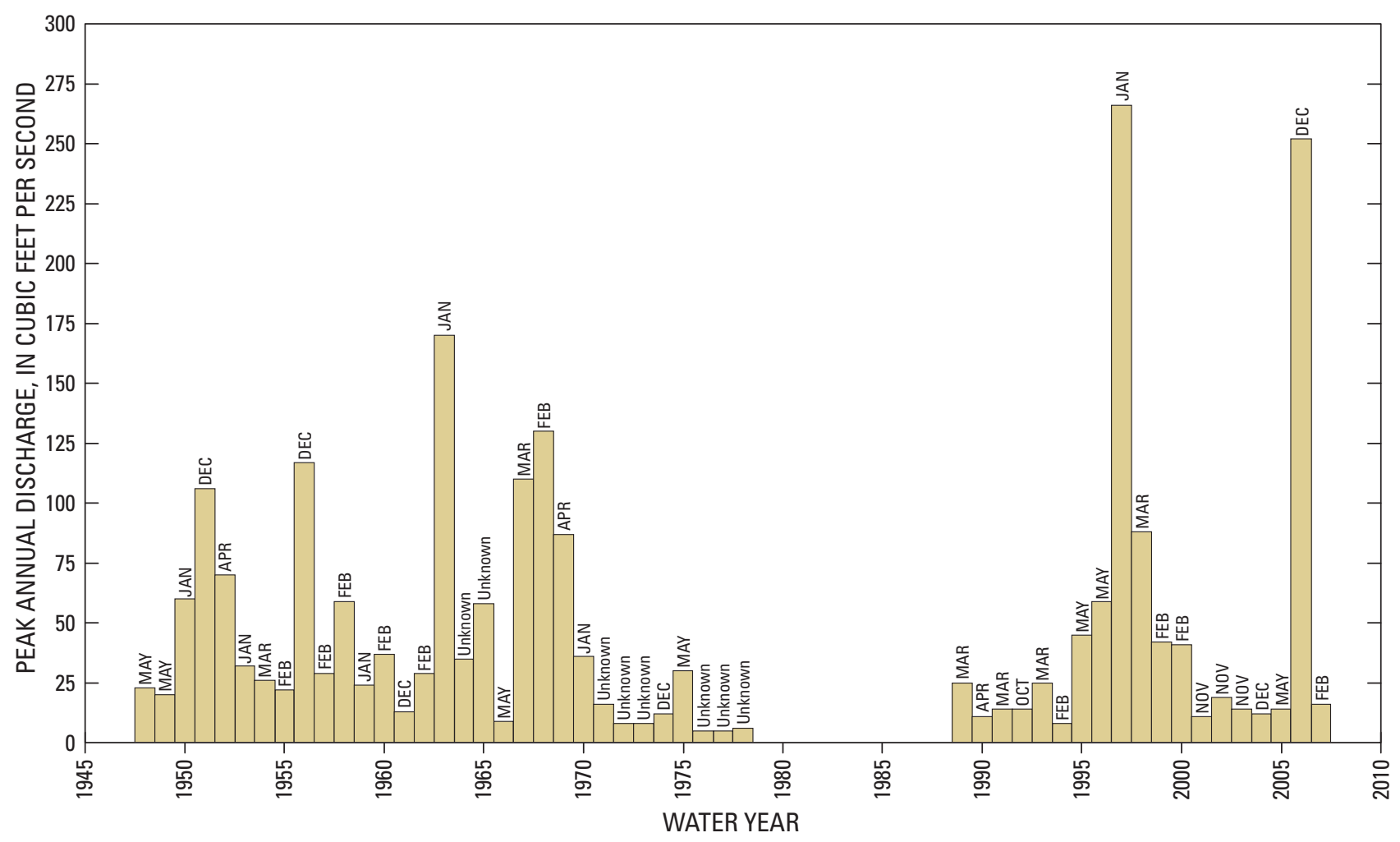

Figure 13. Peak annual discharge at site 2, Clear Creek near Carson City (10310500), Douglas County, Nevada. 


\section{Study Methods}

\section{Selection of Sampling Sites}

Samples were collected at three sites on Clear Creek to characterize sediment-transport characteristics in three distinctive reaches of the creek in the study area. Samples collected at site 1 (fig. 14) represent the undeveloped headwaters upstream of U.S. Highway 50, a $2.4 \mathrm{mi}^{2}$ area dominated by pine and fir forest. Site 1 (Clear Creek above Highway 50 near Spooner Summit; USGS Site Number 10310485) is at an altitude of 6,620 ft and the main channel slope in the 1-mi reach upstream of the site averages $877 \mathrm{ft} / \mathrm{mi}$. Samples are collected upstream of a culvert that carries Clear Creek under U.S. Highway 50. Samples collected at site 2 (fig. 15) represent the reach that extends 5.7 river miles from site 1 downstream to site 2 . This reach starts amid conifer stands at U.S. Highway 50, transitions to an alluvial meadow in the center of the study area, and then enters a narrow bedrock canyon to the gaging station at site 2 . The sampling site is at a concrete flume at USGS gaging station 10310500 (Clear Creek near Carson City) and is downstream of low-density residential areas east of the Clear Creek Youth Center. The site is at an altitude of 5,000 ft in dense riparian vegetation along the creek and a shrub/scrub community in the surrounding mountains. An area of $15.5 \mathrm{mi}^{2}$ drains to site 2. The main channel slope in the 1-mi reach upstream of site 2 averages $308 \mathrm{ft} / \mathrm{mi}$. The third, most downstream study reach extends 1.4 river miles from site 2 to site 3 in Fuji Park. The stream flows out of the narrow canyon downstream of site 2 through a deeply divided alluvial fan to Fuji Park and U.S. Highway 395. Site 3 (Clear Creek at Fuji Park at Carson City; USGS Site Number 10310518) is at an altitude of 4,765 ft and drains an area of $17.8 \mathrm{mi}^{2}$. The main channel slope in the $1-\mathrm{mi}$ reach upstream of the site averages $58 \mathrm{ft} / \mathrm{mi}$. Although site 3 is in a dense stand of willows (fig. 16), it is within a major commercial development in Carson City and Douglas County (figs. 3 and $\underline{5}$ ).

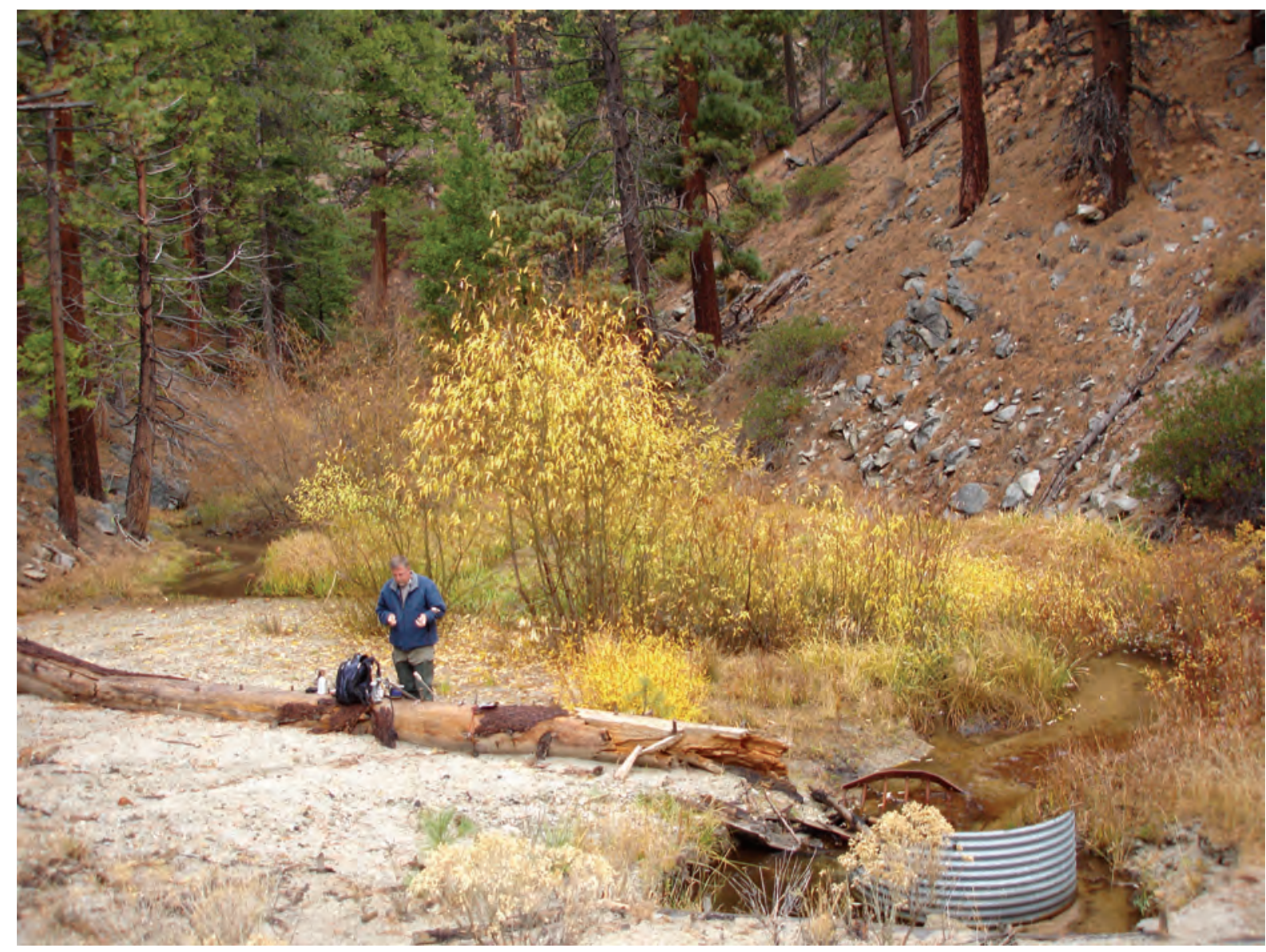

Figure 14. View looking upstream at site 1, Clear Creek above Highway 50, near Spooner Summit (10310485), Carson City, Nevada. Photograph taken by Ralph Seiler, U.S. Geological Survey, November 8, 2006. 


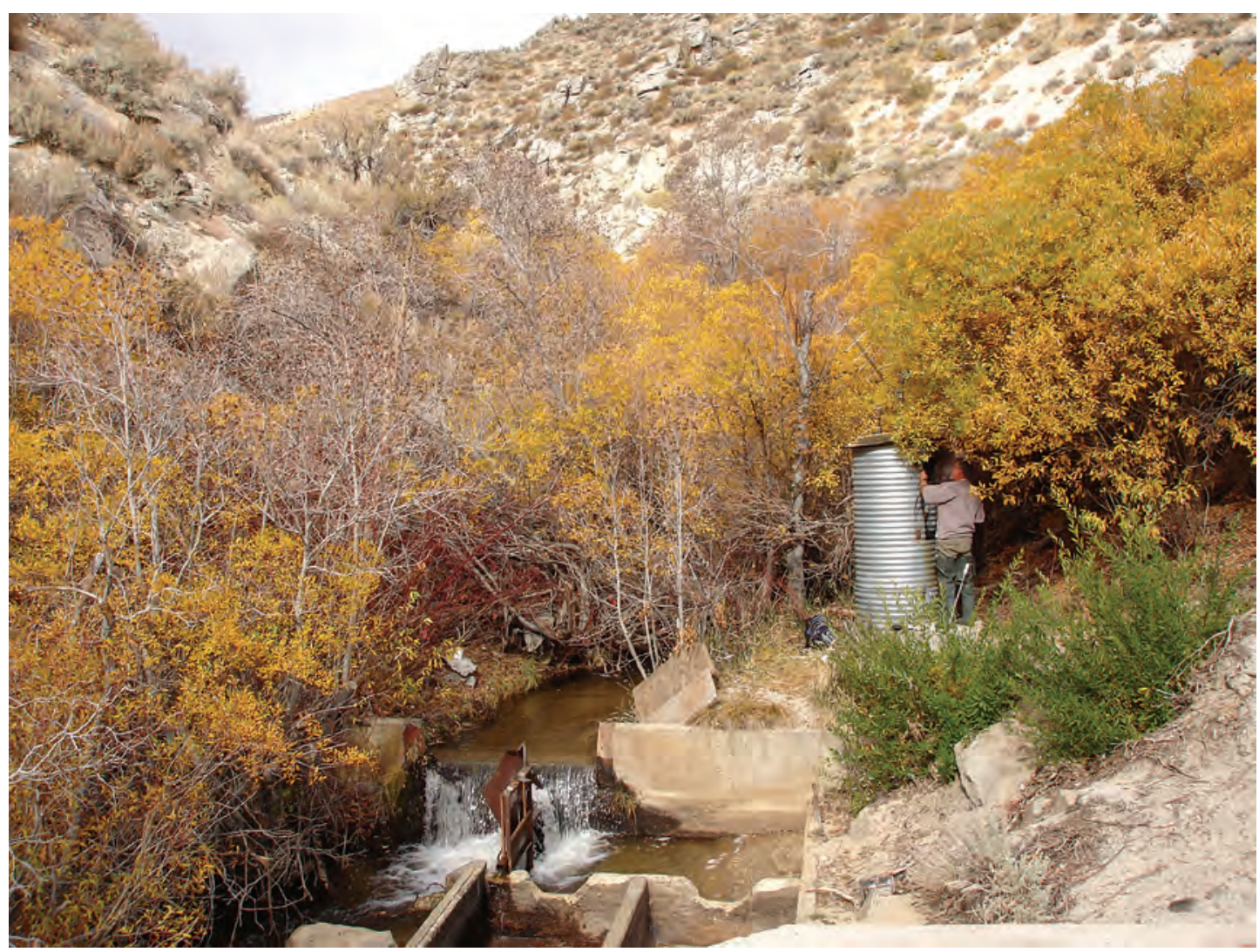

Figure 15. View looking upstream at site 2, Clear Creek near Carson City (10310500), Douglas County, Nevada. Photograph taken by Ralph Seiler, U.S. Geological Survey, November 8, 2006.

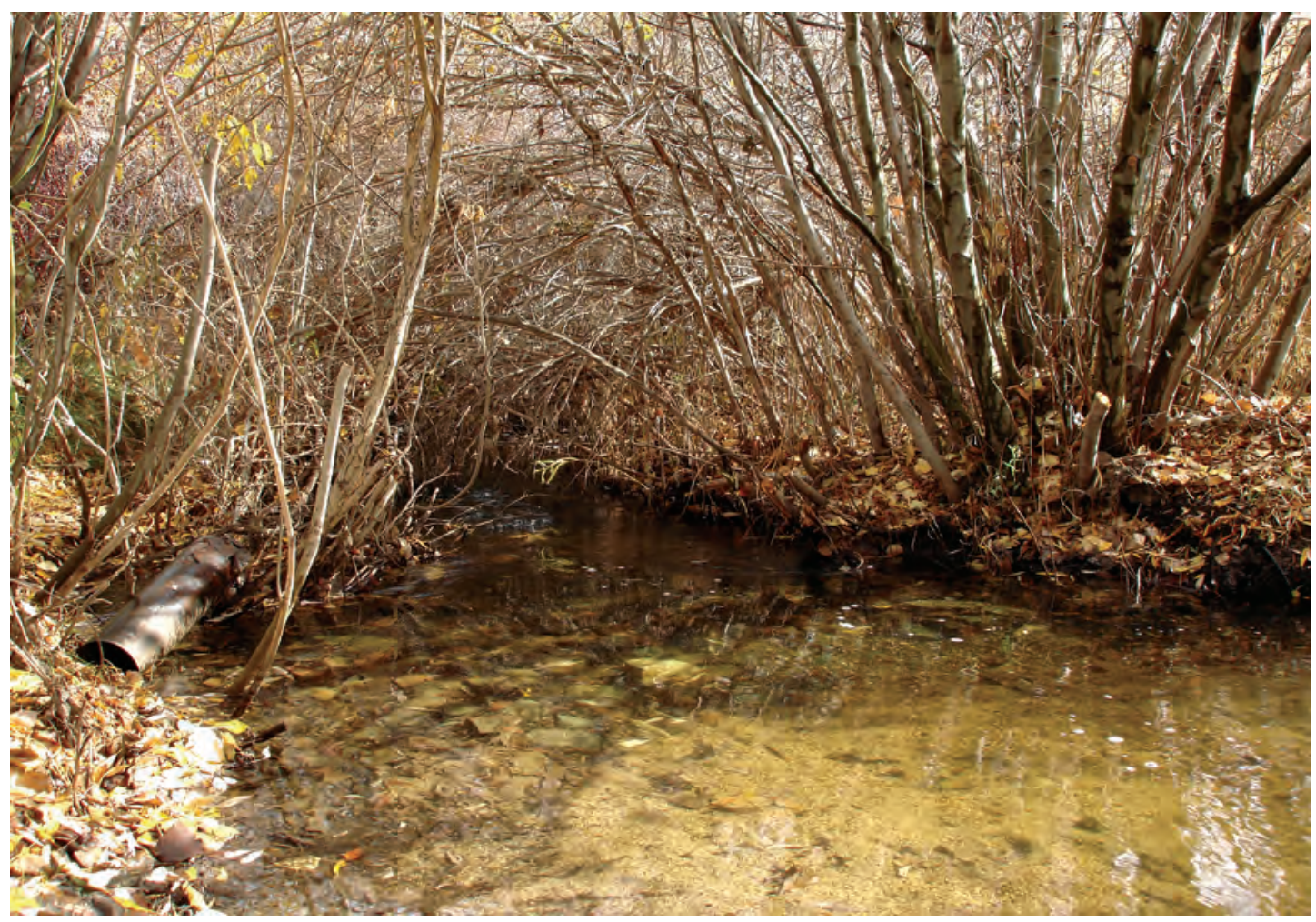

Figure 16. View looking downstream at site 3, Clear Creek at Fuji Park, at Carson City (103100518), Carson City, Nevada. Photograph taken by Ralph Seiler, U.S. Geological Survey, November 8, 2006. 


\section{Collection of Samples and Analysis of Data}

Samples for chemical and sediment analysis were collected from sites 1, 2, and 3 along Clear Creek (fig. 1). Samples for analysis of water chemistry were collected using two methods. Most samples were collected in a DH-81 handheld sampler (Shelton, 1994) using the equal-width increment method, a depth- and width-integration method (Wilde and Radtke, 1998), and were combined in an 8-liter churn splitter. Some samples for chemical analysis at site 2 were collected directly from the weir into the churn splitter. Sample aliquots were taken from the churn splitter, filtered, and preserved in the field, and sent within 1 to 3 days to the USGS National Water Quality Laboratory (NWQL) in Lakewood, Colorado. Analytical methods followed by NWQL are described in Fishman and Friedman (1989). Measurements of temperature, specific conductance, $\mathrm{pH}$, turbidity, and dissolved oxygen were either made in the field or in the Carson City laboratory on the day of sample collection.

Samples to be analyzed for suspended-sediment concentration and sand break (the fraction whose particle size is less than $0.062 \mathrm{~mm}$ ) were collected using a DH-48 sampler (Edwards and Glysson, 1999) or by dipping a glass bottle in the stream. Samples were collected either at a single point in the centroid of flow or at several points distributed in equalwidth increments across the stream. Suspended-sediment samples were analyzed at the USGS sediment lab in Marina, California, using the methods described in Porterfield (1972).

Samples for determination of bedload transport rate and particle-size distribution were collected using a Helley-Smith bedload sampler (Helley and Smith, 1971). The sampler was lowered to the streambed from 20 to 120 seconds at each sampling point, and sampling points were spaced at equal-width intervals (number of intervals ranged from 5 to 14) across the stream where active bedload transport was occurring.

\section{Sediment Transport and Water-Quality Characteristics}

As part of this study, samples for analysis of suspendedand bedload-sediment were collected during periods of baseflow, during periods of peak runoff following storm runoff events, and throughout the spring-runoff period (fig. 17). The streamflow hydrographs for water years 2004-07 at the gaging station Clear Creek near Carson City differ substantially (fig. 17). Winter storms in water year 2006 resulted in three peak discharges that exceeded $10 \mathrm{ft}^{3} / \mathrm{s}$. The peak discharge of $252 \mathrm{ft}^{3} / \mathrm{s}$ on December 31, 2005, was the second highest peak of record for this station. The spring runoff occurred over a longer period in 2007 than in 2006, and there was no pronounced peak discharge in 2007 (fig. 17). Streamflow, field water-quality measurements, and suspended-sediment data from the three Clear Creek sampling sites are listed in appendix 1; bedload-sediment data for site 2, Clear Creek near Carson City (10310500) are listed in appendix 2; and water-quality data are listed in appendix 3 . Fourteen, thirteen, sixteen, and twenty-five suspended-sediment samples were collected during water years 2004, 2005, 2006, and 2007, respectively.

\section{Suspended Sediment}

Suspended-sediment concentrations ranged from 2 to $155 \mathrm{mg} / \mathrm{L}$ at site 1 , from 3 to $468 \mathrm{mg} / \mathrm{L}$ at site 2 , and from 2 to $1,150 \mathrm{mg} / \mathrm{L}$ at site 3 . As is typical of most streams, concentrations of suspended sediment in Clear Creek were greatest during periods of storm runoff (fig. 18).

A comparison of discharge (fig. 19A) for the three stations shows that measurements made within a few hours of each other at sites 2 and 3 are nearly the same at higher values. At a discharge of less than about $5 \mathrm{ft}^{3} / \mathrm{s}$, the limited data suggest that discharge at site 3 is less than discharge at site 2, which is consistent with the loss of water to evapotranspiration along the creek channel during summer when streamflow is low in this reach. Although small amounts of water are diverted for irrigation use immediately downstream of site 2, diversions only occur at night and are not responsible for differences measured during the day between sites 2 and 3. Discharge increased in reach 2 from site 1 to site 2 as the drainage area increased. Although there is considerable scatter in the data, suspended-sediment concentrations (fig. 19B) at the three sites tend to be about the same at low values. At high values, however, suspended-sediment concentrations at sites 1 and 3 tend to be lower than at site 2. Suspended-sediment loads are almost always lower at sites 1 and 3 than those at site 2 (fig. 19C), indicating that sediment is being mobilized in reach 2 (between sites 1 and 2) during both high and low flow. Data also indicate that sediment deposition is occurring within reach 3 between sites 2 and 3 during high flow.

Several factors contribute to the scatter in the data. Clear Creek is shallow in most places less than $1 \mathrm{ft}$ deep. About 50 percent of the samples were collected by dipping bottles into the creek and the remainder were collected using a DH-48 sampler. The DH-48 sampler can be lowered only to $0.29 \mathrm{ft}$ ( $3 \frac{1}{2}$ in.) above the streambed (Davis, 2005), and because the creek is so shallow, a significant part of the vertical water column is not sampled. Collecting samples by the "bottledip" method, however, does not ensure a vertically integrated sample because the largest volume of water in the sample may come from the surface, where the velocity is greatest and the concentration of suspended sediment typically is lowest. In addition, because of the shallow stream depth, both methods of collecting samples are subject to catching sand particles bouncing along the streambed. Because coarse sand particles are massive compared to finer grained silt and clay particles, the presence of even a few grains of sand in a sample can significantly affect the sampled suspended-sediment concentration. 


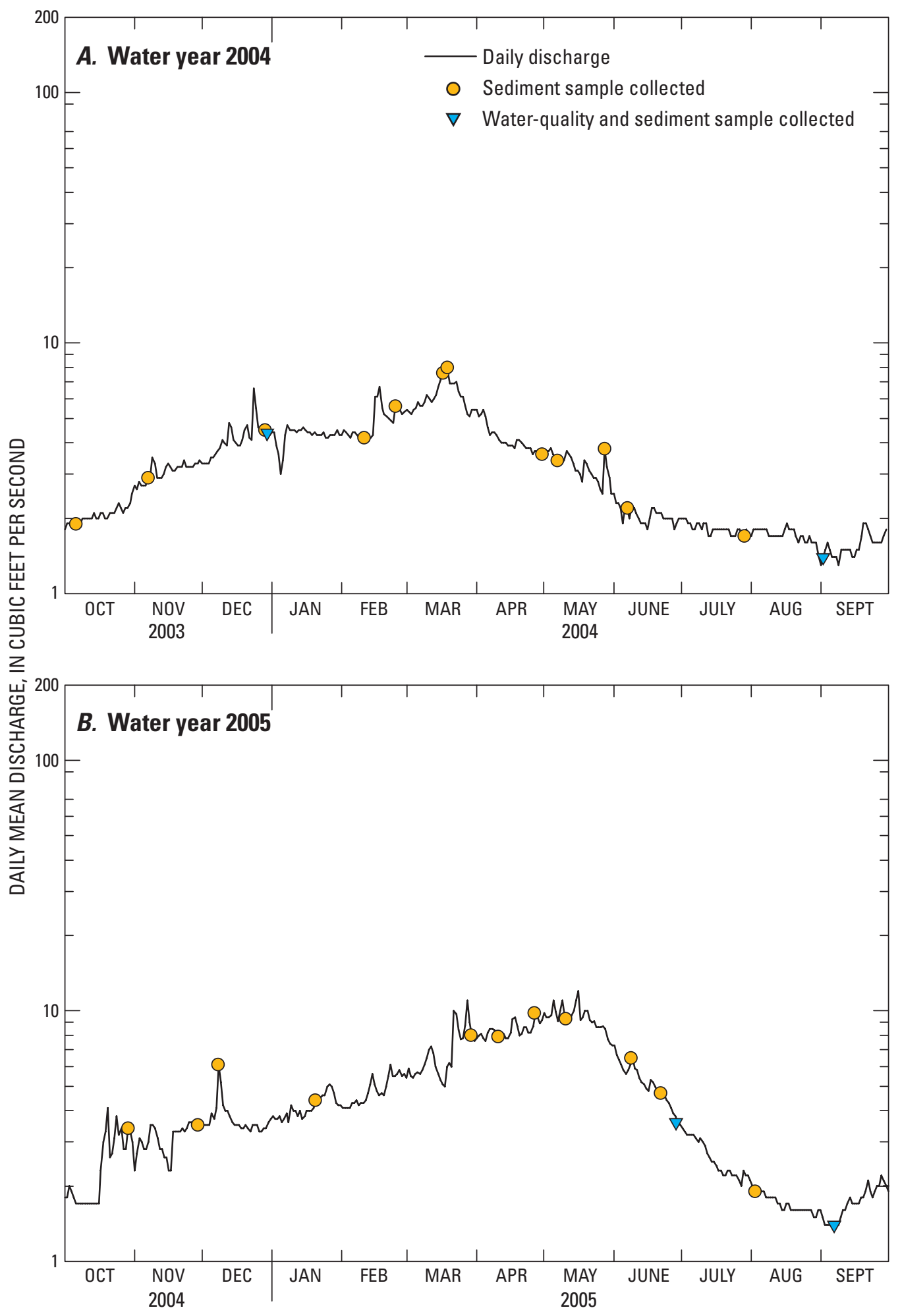

Figure 17. Dates and types of samples collected and daily mean discharge during water years 2004-07 at site 2, Clear Creek near Carson City (10310500), Douglas County, Nevada. 


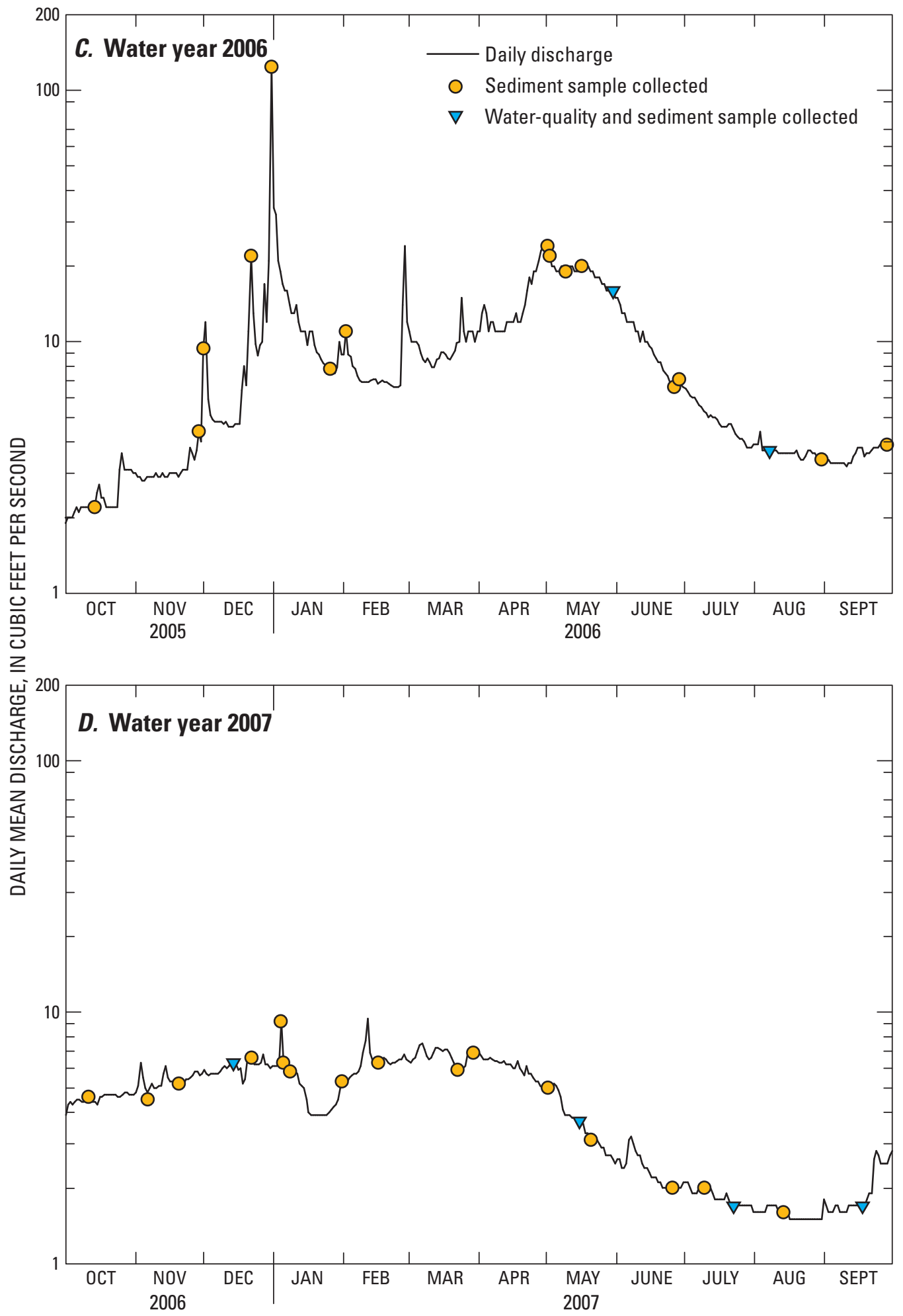

Figure 17.-Continued. 


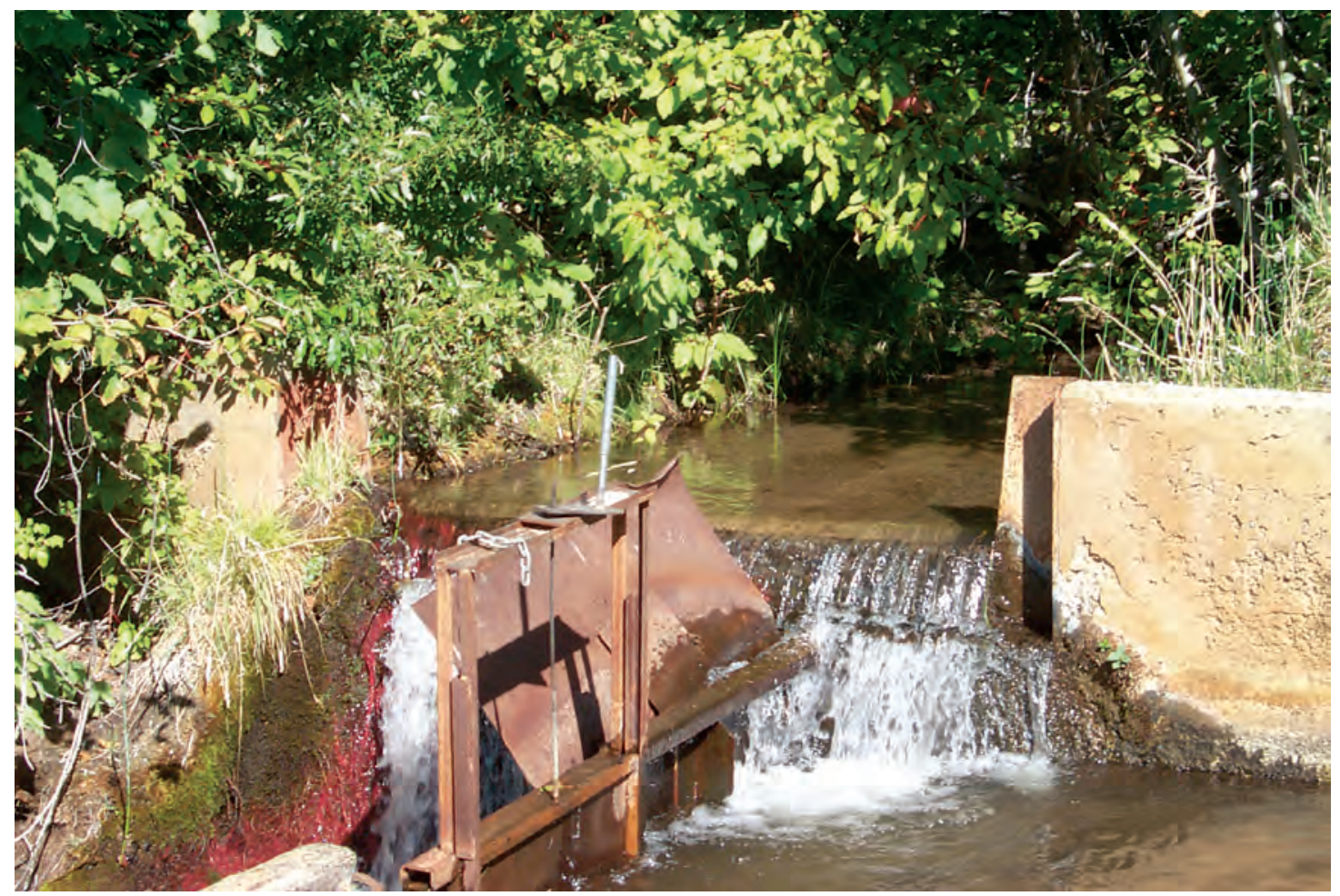

A. Baseflow in September 2007, when discharge was 1.9 cubic feet per second. Photograph taken by Ralph Seiler, U.S. Geological Survey, September 12, 2007.

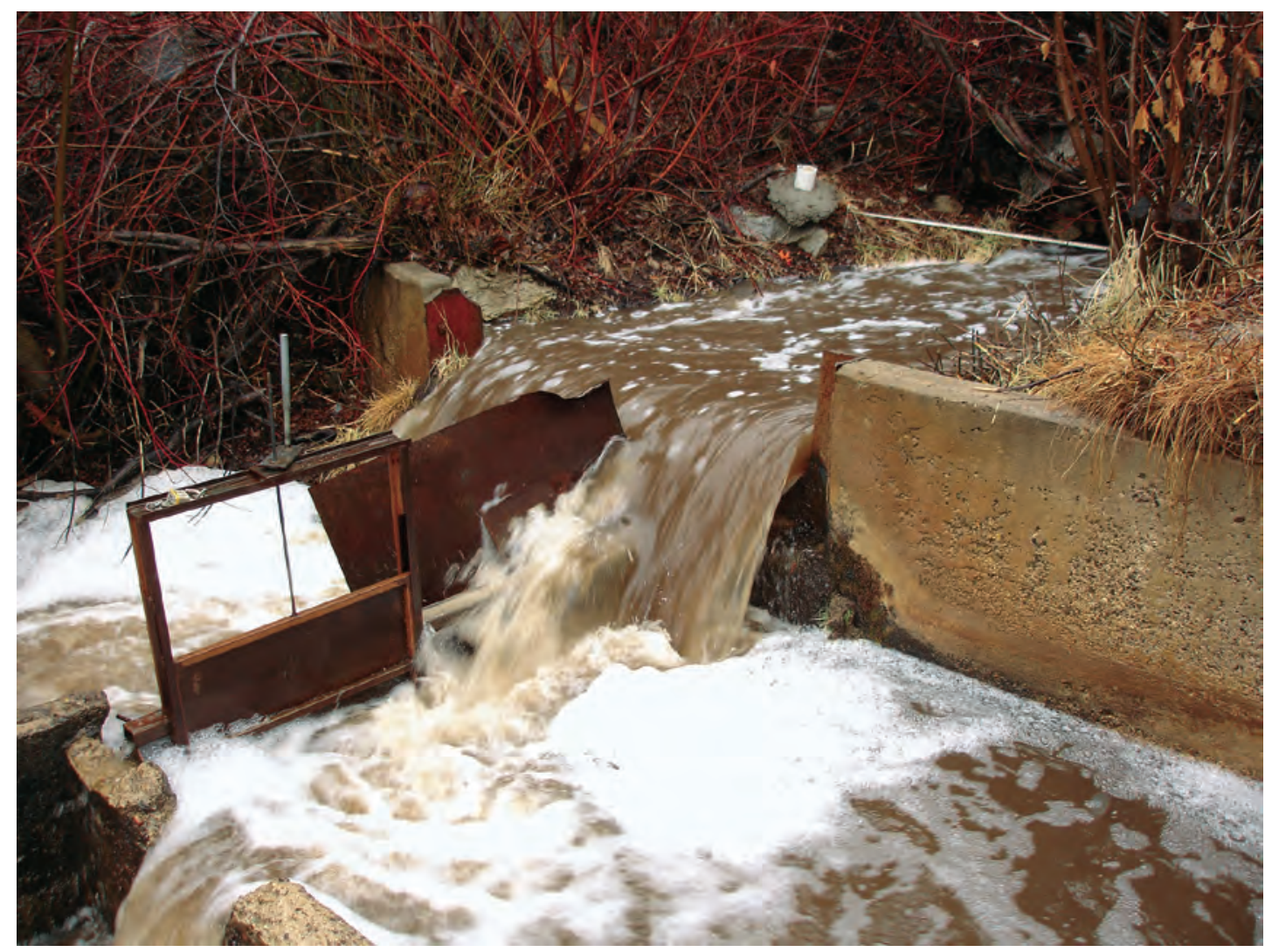

B. Storm runoff in January 2007, when discharge was 13 cubic feet per second. Photograph taken by James Wood, U.S. Geological Survey, January 4, 2007.

Figure 18. View of weir during baseflow and storm runoff at site 2, Clear Creek near Carson City (10310500), Douglas County, Nevada. 

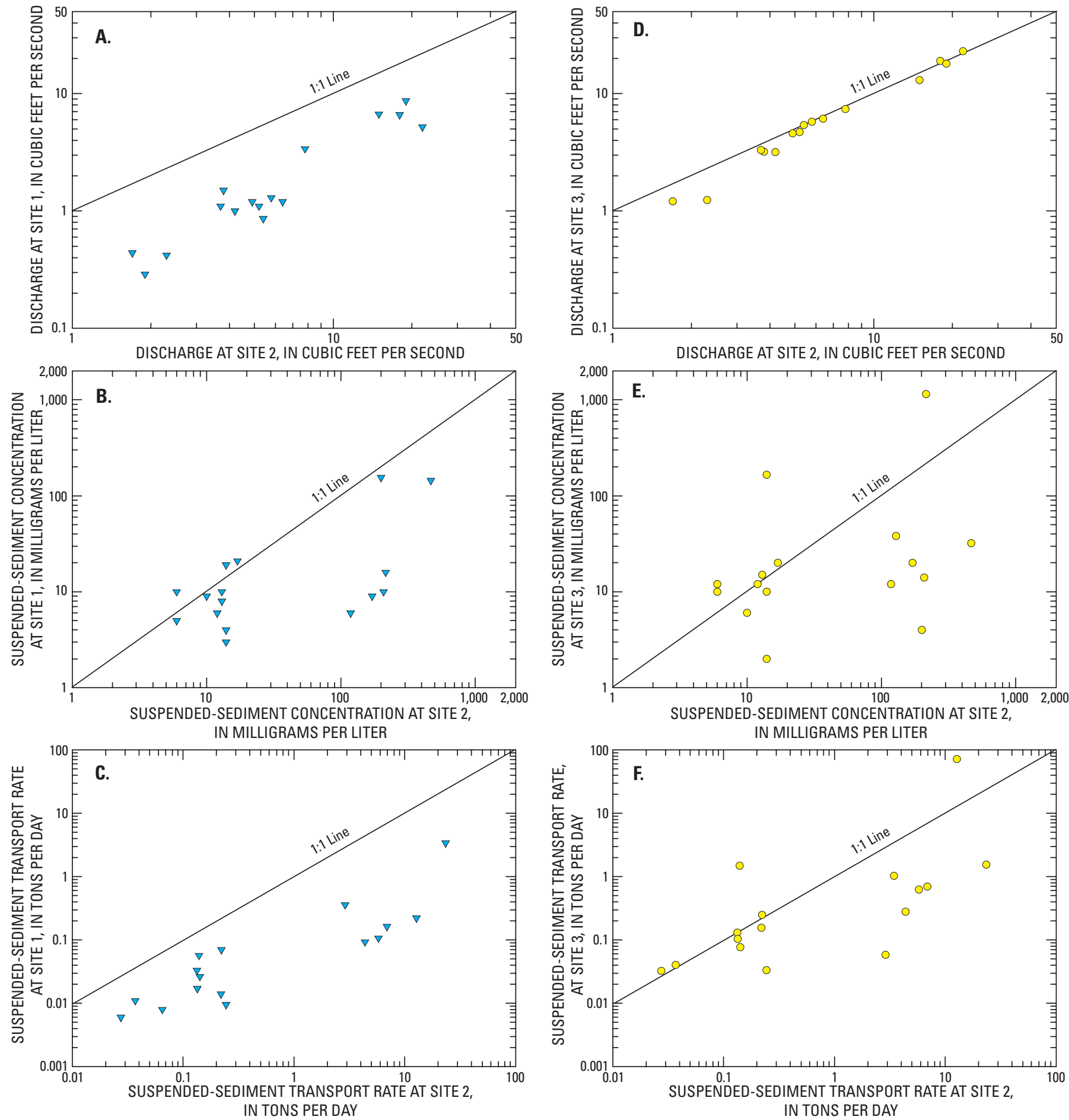

Figure 19. Comparison of discharge, suspended-sediment concentrations, and loads at three sampling sites along Clear Creek, Carson City and Douglas County, Nevada. 
The suspended-sediment transport rate (in tons per day) was calculated by multiplying suspended-sediment concentrations (in milligrams per liter) by measured stream discharge (in cubic feet per second) and by a unit conversion factor (0.002697). Stream discharge and suspended-sediment data were collected at the same time. Typically, current-meter measurements of stream discharge were made concurrently (or almost so) with the collection of samples, but on occasion discharge was computed at site 2 using the stage/discharge relation developed for the gaging station. During one storm event, discharge at site 3 was estimated on the basis of measured discharge at site 2 .

The relation between instantaneous discharge and suspended-sediment transport rate at the three sampling sites is shown in figure 20. Simple linear regression (SLR) analysis was conducted on natural logarithms of transport rate and streamflow using the following model:

where

$$
\ln [\text { rate }]=\beta_{0}+\beta_{1} \ln [Q]+\varepsilon
$$

$\ln []$ denotes the natural logarithm;

rate is the suspended-sediment transport rate;

$\beta_{0}$ is the intercept coefficient;

$\beta_{1}$ is the slope coefficient;

$Q$ is streamflow, in cubic feet per second; and

$\varepsilon$ is random error as residual.

The regression coefficients and coefficient of determination $\left(\mathrm{R}^{2}\right)$ values are shown in figure 20 and listed in table 1 . The $\mathrm{R}^{2}$ values range from 0.51 to 0.77 ; however, relatively high $\mathrm{R}^{2}$ values alone do not guarantee a good model. SLR assumes that model errors or residuals $(\varepsilon)$ are independent and normally distributed, with zero mean and equal variance (Helsel and Hirsch, 1992). Visual inspection of plots of residuals versus predicted values and residuals versus time for the three regressions (not shown) show that there is little evidence of patterns that would indicate the regression models do not sufficiently adhere to the assumptions of SLR. Boxplots of the residuals (not shown) indicate that the residuals are near normally distributed around zero. Kendall's tau test was used to test the correlation between the residuals and the lagged residuals. Kendall's tau was near zero for all three sites and the correlations were not significant, indicating that serial correlation is not a significant problem and that the simple linear regression models are acceptable.

Daily mean suspended-sediment loads at site 2 were calculated for water years 2004-07 using equation 1 . The equation variables are the daily mean discharge from the USGS National Water Information System database and regression coefficients listed in table 1 . The results from the solution of equation 1 were retransformed to estimate suspended-sediment load in the original units. The estimated load in the original units then was multiplied by a 'bias-correction factor' (table 1), which is calculated by transforming the residuals back to the original units, summing them, and then dividing the sum by the number of samples as described by Helsel and Hirsch (1992, p. 257). The regression equations cannot be used directly without applying the biascorrection factor because simply transforming estimates into original units provides an estimate that is biased low (Helsel and Hirsch, 1992, p. 257).

Seasonal and annual suspended-sediment loads for site 2 for water years 2004-07 (table 2) were calculated by summing the daily loads for each year. Suspended-sediment loads for the different water years differ substantially in amount and timing of delivery, with the suspended-sediment load for water year 2006 being eight times greater than water year 2007. The differences in the amounts and seasonality of suspendedsediment loads among the years was caused by differences in hydrologic conditions in those years. Water years 2004, 2005, and 2007 were dry years, and in 2007, there was no distinct spring runoff peak. Annual mean streamflow in 2006 ranged from 1.9 to 2.6 times greater than that for the other years (fig. 12). Furthermore, three large winter storms occurred in water year 2006 but there were no large storm runoff events in the other years (fig. 17). The mean suspended-sediment yield for water years 2004-07 was $35.0\left(\right.$ ton $\left./ \mathrm{mi}^{2}\right) / \mathrm{yr}$.

Table 1. Coefficients and bias-correction factors for regression analysis of suspended-sediment and bedload-transport rates for sampling sites along Clear Creek, Carson City and Douglas Counties, Nevada.

[Dependent variable: The independent variable is streamflow. Abbreviations: SS, suspended sediment]

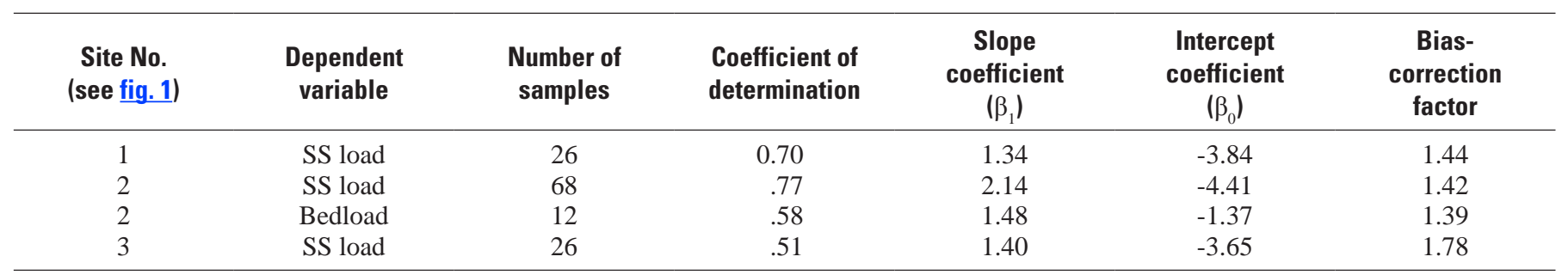




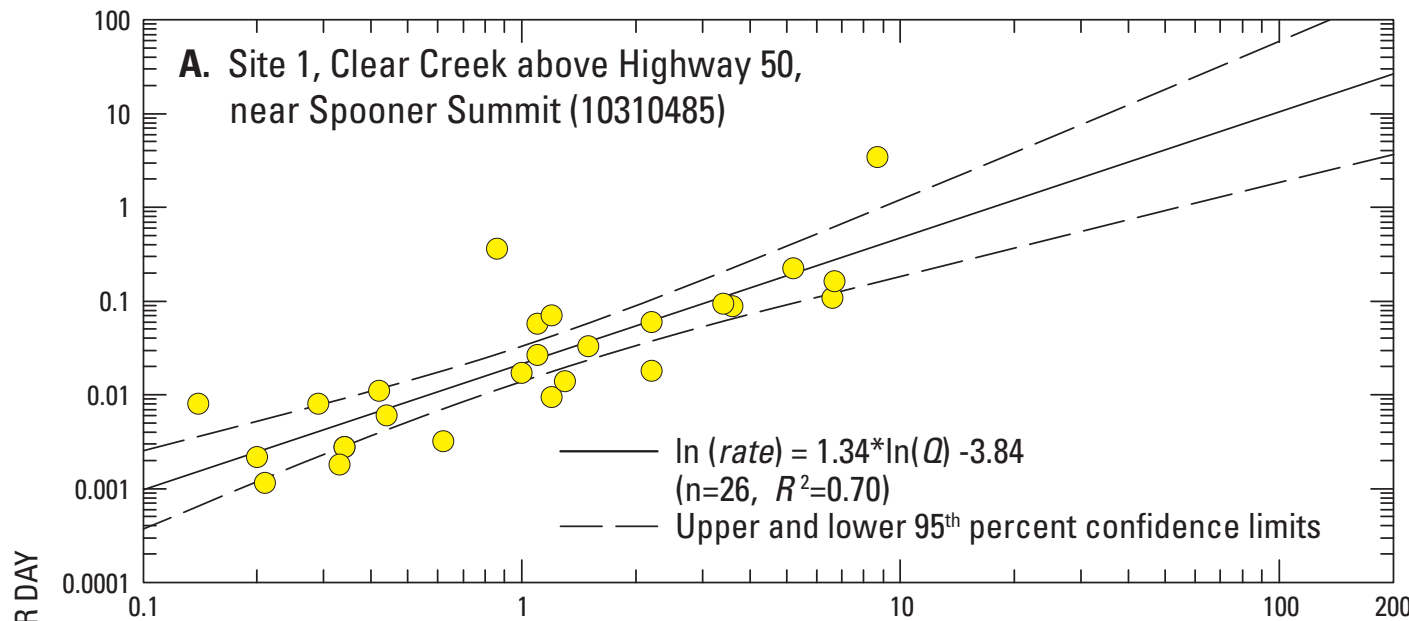



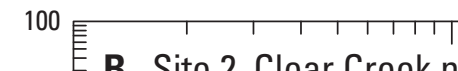

B. Site 2, Clear Creek near

㭊

10 辰 Carson City (10310500)
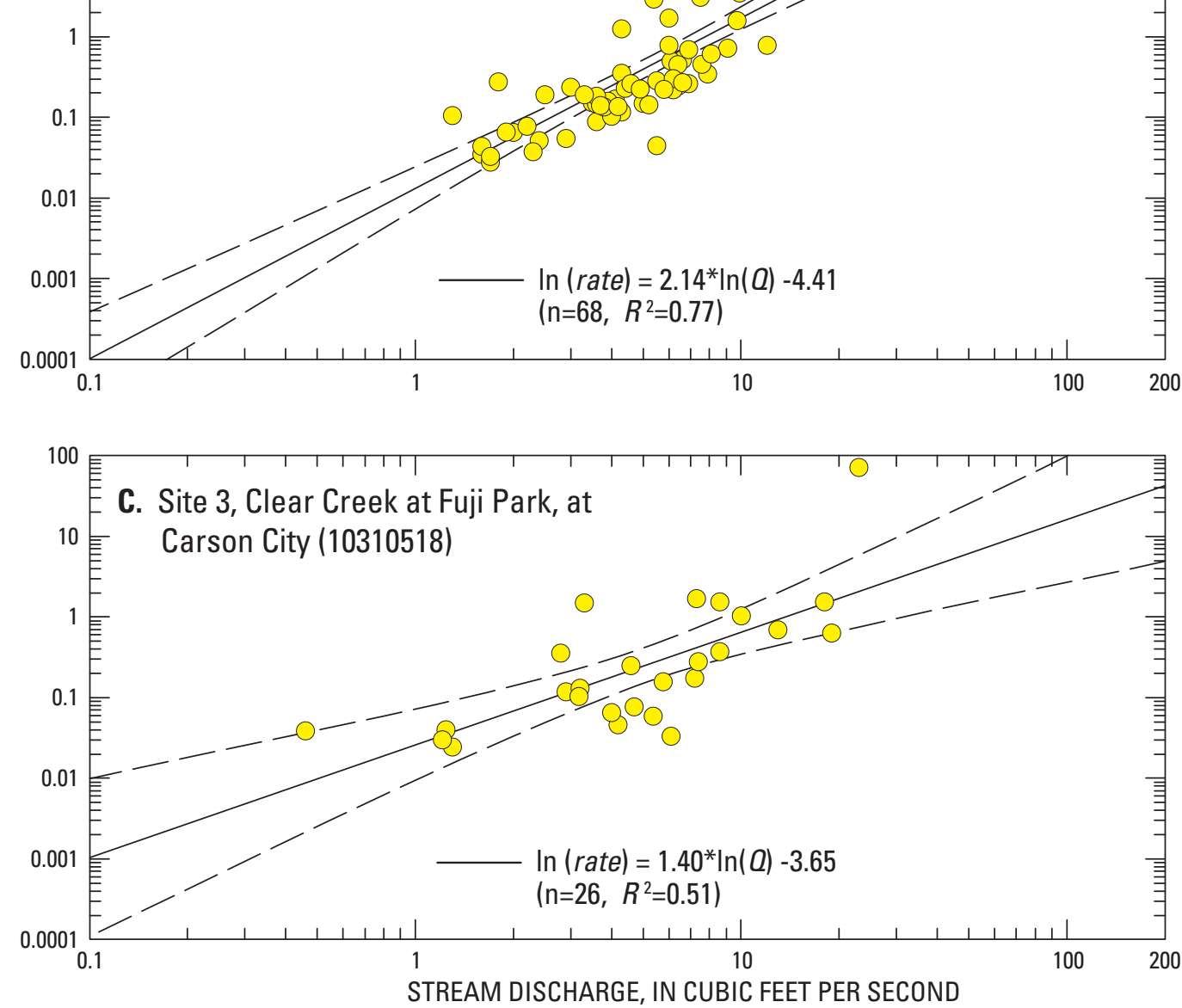

In () denotes the natural logarithm,

rate is suspended-sediment transport rate, in tons per day,

$Q$ is streamflow, in cubic feet per second,

$\mathrm{n}$ is the sample size, and

$R^{2}$ is the coefficient of determination.

Figure 20. Relation between suspended-sediment transport rate and instantaneous discharge for three sampling sites along Clear Creek, Carson City and Douglas County, Nevada. 
The estimated suspended-sediment load during December 2005 was 588 tons, and was 520 tons on December 31, 2005. The suspended-sediment load on that one day alone is greater than the combined suspended-sediment loads for water years 2004, 2005, and 2007.

\section{Bedload}

About 80 percent of the bedload transported in Clear Creek is composed of sand, with most of it being coarse to very coarse sand (fig. 21, appendix 2), with gravel accounting for the remainder. For comparison, the median sand break for suspended sediment (fig. 21, appendix 1) is 50 percent.

Total sediment-transport rate was determined in most cases as the sum of concurrent measurements of suspendedsediment and bedload-transport rates (appendixes 1 and 2). On one occasion in May 2007, the total-sediment transport rate was determined directly by collecting a sample from the weir and suspended-sediment transport rate was determined in the normal manner. Bedload- transport rate was calculated by subtracting the suspended-sediment transport rate from the total-sediment transport rate. For all samples, the bedloadtransport rate averaged 73 percent of the total-sediment transport rate, but there was significant variability (a range of 6 to 92 percent) in the proportion of bedload to total load. The variability is to be expected because the water velocity required to move a sediment particle depends on its size and density, properties that can vary considerably for both suspended and bedload particles.

The relation between instantaneous discharge and bedload transport rate at site 2 is shown in figure 22. SLR analysis was conducted on natural logarithms of the values of the bedload transport rate and discharge following methods described previously. The regression coefficients and coefficient of determination $\left(\mathrm{R}^{2}\right)$ values are shown in figure 22 and listed in table 1. Visual inspection of plots of residuals versus predicted values (not shown) indicate little evidence of pattern and a boxplot of the residuals (not shown) indicate that the residuals are near normally distributed around zero. The lack of correlation between the residuals and the lagged residuals indicates that serial correlation is not a significant problem. This regression should be used with considerable caution, however, because of the limited number of data points and the wide confidence limits for the regression.

Annual bedloads for site 2 for water years 2004-07 were estimated by summing the daily loads for each year (table 2). Estimated annual bedload ranged from 790 tons for water year 2004 to 3,830 tons for water year 2006 .

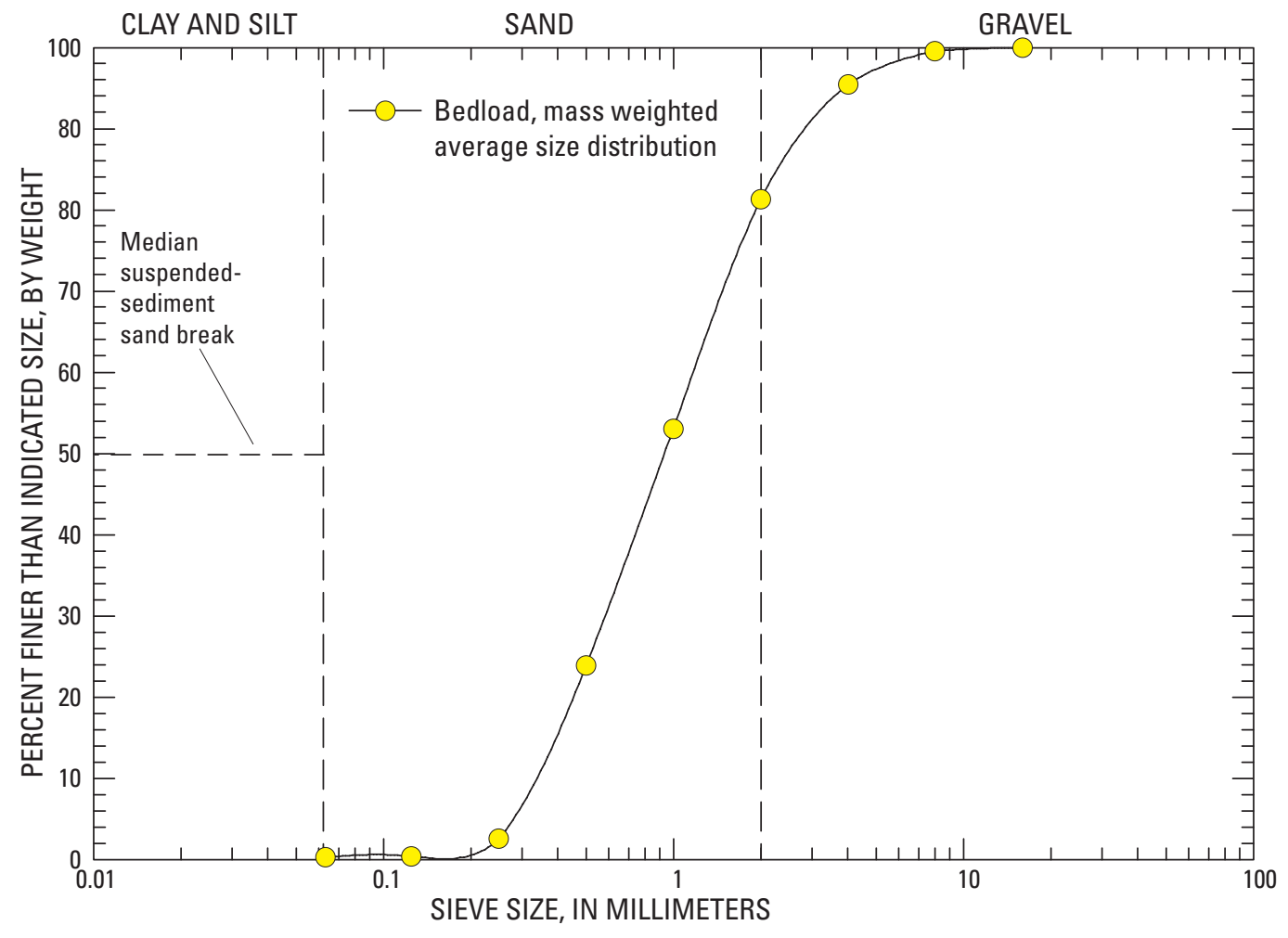

Figure 21. Particle-size distribution of bedload and suspended sediment for site 2, Clear Creek near Carson City (10310500), Douglas County, Nevada. 


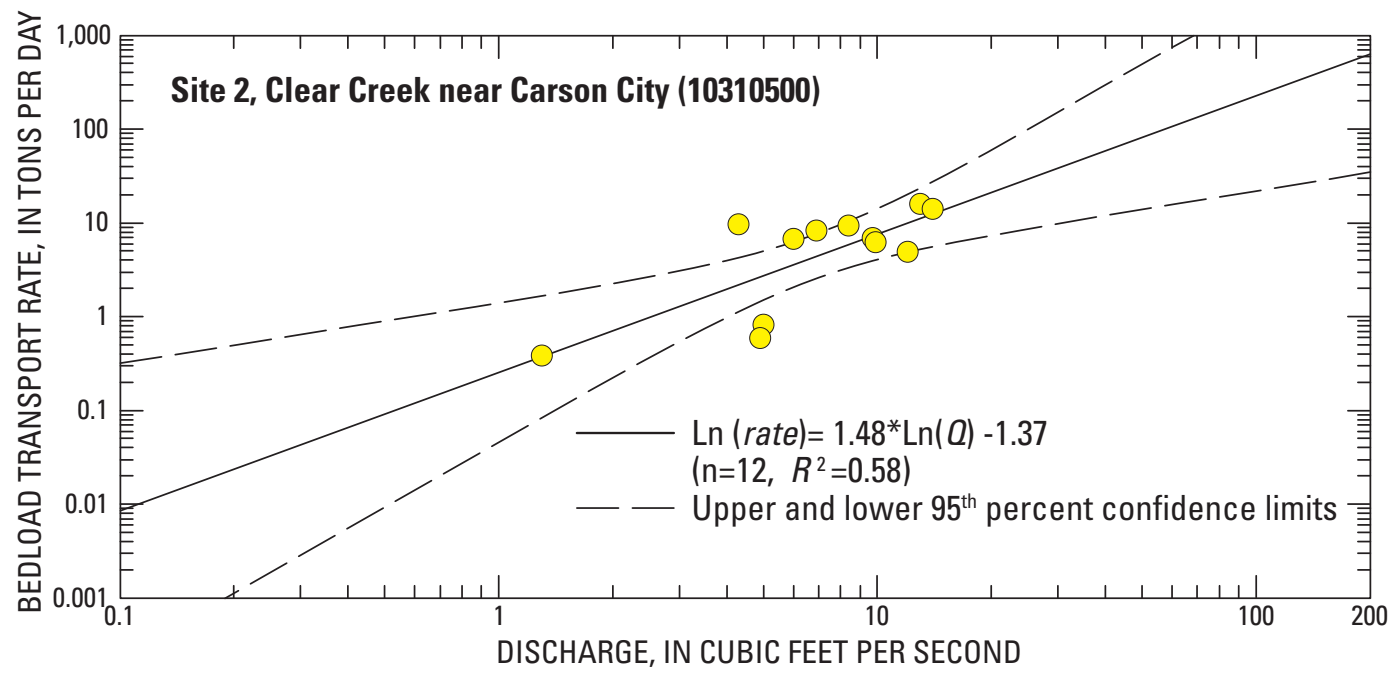

\begin{abstract}
In ( ) denotes the natural logarithm, rate is bedload transport rate, in tons per day,

$Q$ is streamflow, in cubic feet per second,

$\mathrm{n}$ is the sample size, and

$R^{2}$ is the coefficient of determination.
\end{abstract}

Figure 22. Relation between bedload transport rate and instantaneous discharge for site 2, Clear Creek near Carson City (10310500), Douglas County, Nevada.

Table 2. Estimated seasonal and annual suspended-sediment loads and average annual bedload and suspended-sediment yield for site 2, Clear Creek near Carson City (10310500), Douglas County, Nevada.

[Autumn (October 1-December 31); Winter (January 1-March 31); Spring (April 1-June 30); Summer (July 1-September 30). Abbreviations: ft 3 /s, cubic feet per second; $\left(\mathrm{t} / \mathrm{mi}^{2}\right) / \mathrm{yr}$, tons per square mile per year]

\begin{tabular}{|c|c|c|c|c|c|c|c|c|}
\hline \multirow{2}{*}{$\begin{array}{l}\text { Water } \\
\text { year }\end{array}$} & \multirow{2}{*}{$\begin{array}{c}\text { Annual } \\
\text { mean } \\
\text { discharge } \\
\left(\mathbf{f t}^{3} / \mathbf{s}\right)\end{array}$} & \multicolumn{5}{|c|}{ Suspended-sediment load (tons) } & \multirow{2}{*}{$\begin{array}{c}\text { Annual } \\
\text { bedload } \\
\text { (tons) }\end{array}$} & \multirow{2}{*}{$\begin{array}{l}\text { Average annual } \\
\text { suspended- } \\
\text { sediment yield } \\
{\left[\left(\mathrm{t} / \mathrm{mi}^{2}\right) / \mathrm{yr}\right]}\end{array}$} \\
\hline & & Autumn & Winter & Spring & Summer & Annual & & \\
\hline 2004 & 3.26 & 20 & 54 & 21 & 5 & 100 & 790 & 6.4 \\
\hline 2005 & 4.50 & 19 & 61 & 133 & 8 & 221 & 1,320 & 14.2 \\
\hline 2006 & 8.64 & 598 & 287 & 537 & 34 & 1,456 & 3,830 & 93.9 \\
\hline 2007 & 4.28 & 58 & 76 & 37 & 6 & 177 & 1,180 & 11.4 \\
\hline
\end{tabular}




\section{Turbidity}

In some areas, continuous monitoring of instream turbidity allows continuous suspended-sediment transport rates to be estimated (Uhrich and Bragg, 2003). Such monitoring, however, did not prove practicable in the Clear Creek study area. A plot of the regression between suspended-sediment transport rate and turbidity for site $2\left(\mathrm{R}^{2}=0.63\right.$; fig. 23$)$ shows that there is more scatter in the data for this regression than for the regression between suspended-sediment transport rate and discharge (ig. 20). Furthermore, a plot of residuals versus predicted values (not shown) is curved and the residuals are not normally distributed around zero, indicating the regression model does not adhere sufficiently to the assumptions of SLR to be used.

Uhrich and Bragg (2003) stated that the amount of larger particles relative to smaller particles can significantly alter the relation between turbidity and suspended-sediment concentrations. Turbidity is a measure of the light scattering and absorption properties of a sample. These properties are affected by the size, shape, and refractive index of the particles in suspension (Eaton and others, 1995), and the poor relation between turbidity and suspended sediment concentrations in the samples collected in this study is probably due to the large amount of sand-sized particles in many of the samples. The sand-sized particles can settle rapidly during sample measurement, and their rough, irregular surfaces can scatter light unpredictably.

\section{Water Quality}

The stream water at the three Clear Creek sites is a dilute calcium/sodium bicarbonate water with low nutrient concentrations. Field $\mathrm{pH}$ values ranged between 6.0 and 8.2 (median 7.8) and specific conductance ranged between 40 and $244 \mu \mathrm{S} / \mathrm{cm}$. These findings agree in general with those of Fritchel (2003), who summarized water-quality data for 13 samples routinely collected by Nevada Division of Environmental Protection (NDEP) at site 2 from 1999 to 2002. Field $\mathrm{pH}$ values for the NDEP samples ranged between 6.9 and 8.9 (median 8.1). Except for turbidity, chemical constituents met U.S. Environmental Protection Agency (USEPA) primary and secondary drinking-water standards. During baseflow periods, turbidity did not exceed the turbidity standard of 5 NTU; during spring runoff and storm events, however, the standard was exceeded at all of the sampling sites. Total nitrogen concentrations (sum of organic nitrogen, ammonia, and nitrite plus nitrate) and total phosphorus concentrations were always less than 0.2 and less than $0.088 \mathrm{mg} / \mathrm{L}$, respectively. For the NDEP samples collected from 1999 to 2002 at site 2, total nitrogen concentrations were always less than $1 \mathrm{mg} / \mathrm{L}$ (median $0.31 \mathrm{mg} / \mathrm{L}$ ) and total phosphorus concentrations were always less than $0.1 \mathrm{mg} / \mathrm{L}$ (median $0.04 \mathrm{mg} / \mathrm{L}$ ).

Concentrations of total dissolved solids, determined as the sum of the concentrations of all measured constituents, were nearly the same at site 2 (range 90 to $125 \mathrm{mg} / \mathrm{L}$ ) and site 3 (range 93 to $118 \mathrm{mg} / \mathrm{L}$ ). For samples collected on the same day, total dissolved solids concentrations were 1.6 to 2.7 times greater at site 2 than upstream at site 1 (range 39 to $74 \mathrm{mg} / \mathrm{L}$ ). For the NDEP samples collected at site 2 from 1999 to 2002, total dissolved solids concentrations ranged from 96 to $174 \mathrm{mg} / \mathrm{L}$ (median $108 \mathrm{mg} / \mathrm{L}$ ) (Fritchel, 2003).

Chloride concentrations greatly increased in reach 2; during this study, all chloride concentrations were less than $0.5 \mathrm{mg} / \mathrm{L}$ at site 1 and ranged from 5.01 to $23.9 \mathrm{mg} / \mathrm{L}$ at site 2 (appendix 3). Chloride concentrations did not increase between sites 2 and 3; however, samples for direct comparison were collected on only 3 days. The contributing area for reach 2 is 6.5 times larger than that for reach 1 , so that some increases in major ion concentrations would be expected, However, for samples collected on the same days in May 2006 and 2007, chloride concentrations increased from 39 to 79 times across reach 2, whereas calcium concentrations increased only 2 to 3 times. This suggests that the chloride may be contributed by anthropogenic activities or sources, such as road salting or septic systems, because the soils and geology are similar in reaches 1 and 2 (figs. 8 and 9 ). Fluctuations in chloride concentrations at site 2 are strongly seasonal (fig. 24) — chloride concentrations are greatest during late winter and spring whereas calcium concentrations do not show such a strong seasonal fluctuation. The seasonal variability in the concentrations of chloride likely indicates that the source of the chloride is the salting of roads during winter to control icing. If the primary source of chloride were septic systems, concentrations would be greatest during baseflow in late summer, when dilution of effluent by streamwater would be the least. 

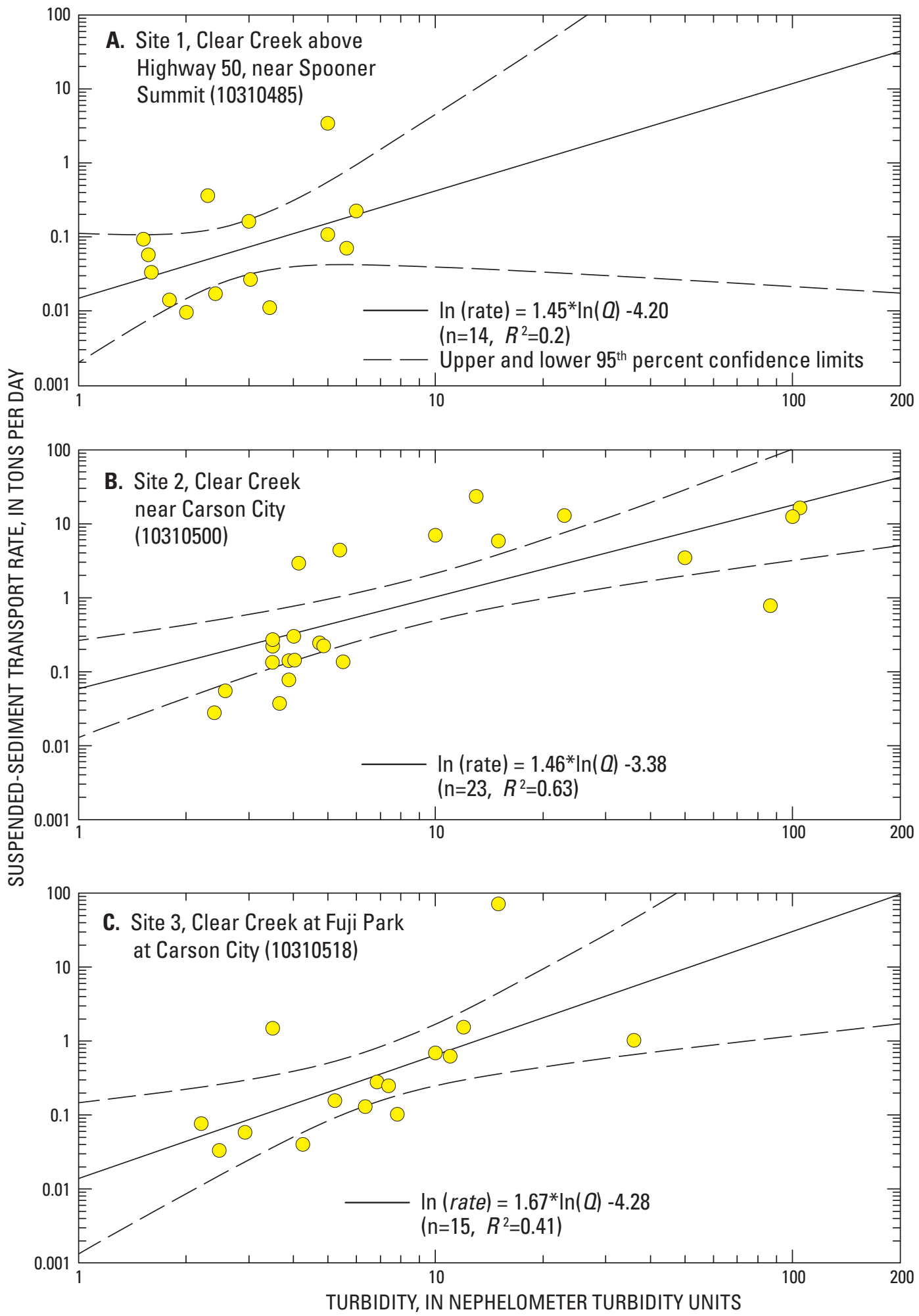

In () denotes the natural logarithm,

rate is suspended-sediment transport rate, in tons per day,

$Q$ is streamflow, in cubic feet per second,

$\mathrm{n}$ is the sample size, and

$R^{2}$ is the coefficient of determination.

Figure 23. Relation between suspended-sediment transport rate and turbidity for three sampling sites along Clear Creek, Carson City and Douglas County, Nevada. 


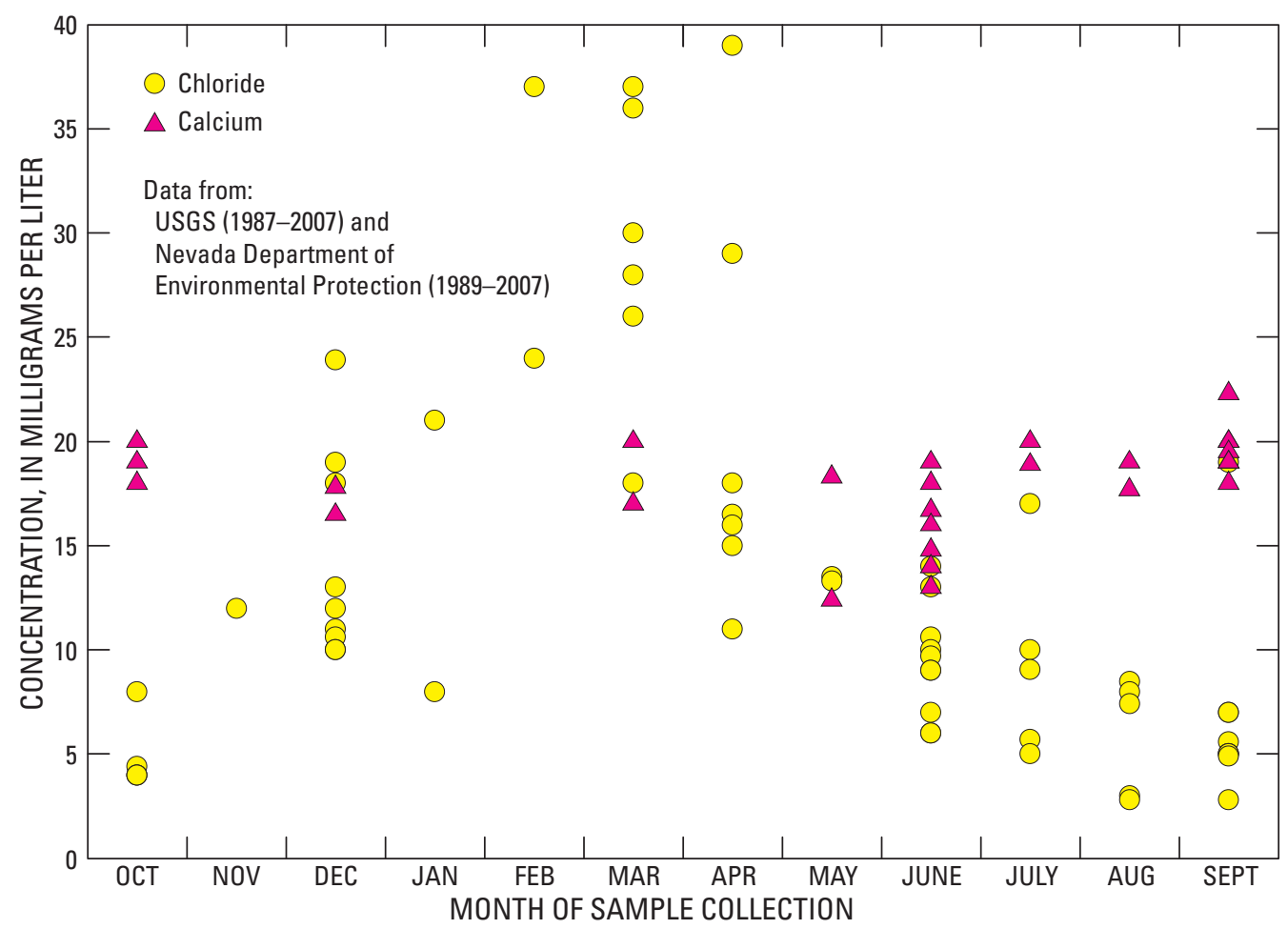

Figure 24. Seasonal distribution in concentrations of chloride and calcium at site 2, Clear Creek near Carson City (10310500), Douglas County, Nevada.

\section{Comparison of Clear Creek and Lake Tahoe Basin Streams}

Measurements made at three streams in the adjacent Lake Tahoe basin during water years 2004-07 by USGS as part of the Lake Tahoe Interagency Monitoring Program (LTIMP) were used to develop regression equations between suspended-sediment transport rate and discharge (fig. 25). The mean annual suspended-sediment yield for the streams for water years 2004-07 (table 3) were compared to values for Clear Creek for the same period. Suspended-sediment yield for the three Lake Tahoe creeks ranged from 2.4 to $7.0\left(\mathrm{t} / \mathrm{mi}^{2}\right) / \mathrm{yr}$ compared to $31.5\left(\mathrm{t} / \mathrm{mi}^{2)} / \mathrm{yr}\right.$ for Clear Creek. Several factors could account for the differences in sediment transport and yield. The Logan House Creek drainage basin is less developed than the Clear Creek drainage basin, but there is more residential and commercial development in the Edgewood and Glenbrook basins than in the Clear Creek basin. A large retention basin is located above the Edgewood Creek gaging station and numerous beaver dams are upstream of the Glenbrook Creek gaging station. Erosion related to U.S. Highway 50 likely differs among the drainage basins as well. In the Clear Creek and Glenbrook Creek drainage basins, U.S. Highway 50 parallels the creeks for long stretches through areas with large roadcuts upstream of the gaging stations. In the Logan House Creek and Edgewood Creek drainage basins, U.S. Highway 50 passes through lower parts of the basins and the highway is downstream of the Logan House gaging station. 

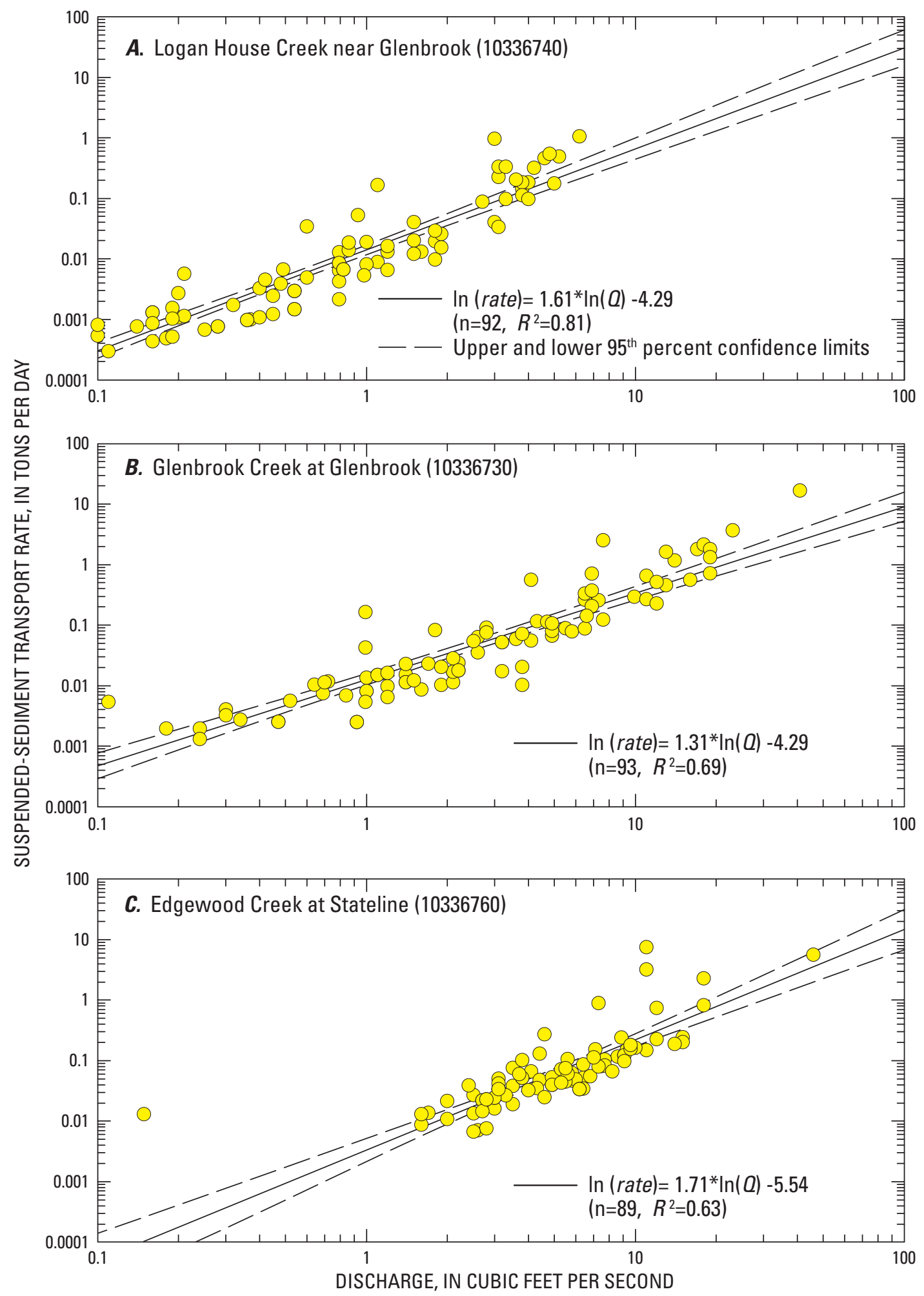

In () denotes the natural logarithm, rate is suspended-sediment transport rate, in tons per day, $Q$ is streamflow, in cubic feet per second, $\mathrm{n}$ is the sample size, and $R^{2}$ is the coefficient of determination.

Figure 25. Relation between suspended-sediment transport rate and instantaneous discharge for three nearby streams in the adjacent Lake Tahoe basin, Nevada. 
Table 3. Comparison of suspended-sediment yield for Clear Creek and three nearby streams in the adjacent Lake Tahoe basin, Nevada.

[Range of values is shown in parentheses. Abbreviations: $\mathrm{ft}^{3} / \mathrm{s}$, cubic foot per second; $\mathrm{mi}^{2}$, square mile; $\left(\mathrm{t} / \mathrm{mi}^{2}\right) / \mathrm{yr}$, ton per square mile per year]

\begin{tabular}{|c|c|c|c|c|}
\hline \multirow{2}{*}{$\begin{array}{c}\text { Stream } \\
\text { (USGS station ID) }\end{array}$} & \multirow{2}{*}{$\begin{array}{l}\text { Basin area } \\
\quad\left(\mathrm{mi}^{2}\right)\end{array}$} & \multirow{2}{*}{$\begin{array}{c}\text { 2004-07 mean } \\
\text { annual discharge } \\
\left(\mathbf{f t t}^{3} / \mathbf{s}\right)\end{array}$} & \multicolumn{2}{|c|}{$\begin{array}{l}\text { 2004-07 mean annual } \\
\text { suspended sediment }\end{array}$} \\
\hline & & & $\begin{array}{l}\text { Load } \\
(\mathrm{t} / \mathrm{yr})\end{array}$ & $\begin{array}{c}\text { Yield } \\
\left.\left[\left(\mathrm{t} / \mathrm{mi}^{2}\right) / \mathrm{yr}\right)\right]\end{array}$ \\
\hline Edgewood Creek (10336760) & 5.61 & $\begin{array}{c}4.51 \\
(2.94-6.40)\end{array}$ & $\begin{array}{c}28.6 \\
(13.4-50.7)\end{array}$ & $\begin{array}{c}5.1 \\
(2.4-9.0)\end{array}$ \\
\hline Logan House Creek (10336740) & 2.09 & $\begin{array}{c}0.53 \\
(0.31-0.83)\end{array}$ & $\begin{array}{c}4.9 \\
(1.9-9.9)\end{array}$ & $\begin{array}{c}2.4 \\
(0.9-4.7)\end{array}$ \\
\hline Glenbrook Creek (10336730) & 4.1 & $\begin{array}{c}2.07 \\
(1.12-3.69)\end{array}$ & $\begin{array}{c}28.7 \\
(11.8-58.2)\end{array}$ & $\begin{array}{c}7.0 \\
(2.9-14.2)\end{array}$ \\
\hline Clear Creek (10310500) & 15.5 & $\begin{array}{c}5.17 \\
(3.26-8.64)\end{array}$ & $\begin{array}{c}488 \\
(100-1,456)\end{array}$ & $\begin{array}{c}31.5 \\
(6.4-93.9)\end{array}$ \\
\hline
\end{tabular}

\section{Comparison of Results With Previous Investigations}

Brown and Skau (1977) measured specific conductance and the concentrations of suspended sediment in Clear Creek as part a regional study of water quality in streams along the east-central Sierra Nevada. The average specific conductance for 14 samples collected just upstream of Fuji Park between September 1972 and September 1973 was $130 \mu \mathrm{S} / \mathrm{cm}$ (range 108-148 $\mu \mathrm{S} / \mathrm{cm}$ ) (Brown and Skau, 1977). The average specific conductance for 22 measurements made at site 3 during this study (appendix 1) was $172 \mu \mathrm{S} / \mathrm{cm}$ (range 137-244 $\mu \mathrm{S} / \mathrm{cm}$ ). These data indicate that there have been changes in water quality in the creek over the last 30 years that probably are due to application of road salt during winter to control icing.

A comparison of the relation between suspendedsediment transport rate and discharge in Clear Creek near Fuji Park on the basis of data collected in 1973-75 (Brown and Skau, 1977) and during this investigation shows that the slopes of the regression lines are different and that suspendedsediment transport rates tended to be higher in water years 1973-75 than in water years 2004-07 (fig. 26). Because of the considerable overlap in the data, however, and the fact that the data were collected at different locations, it is difficult to evaluate to what extent the fundamental sedimenttransport characteristics of the basin have changed over the last 30 years. In water years 1973-75, data were collected just upstream of Fuji Park, whereas in water years 2004-07, data were collected at the downstream end of the park. The difference in the regression lines may be a consequence of data collection at different sites because the reach between the sites across Fuji Park likely is an area of sediment deposition.
The annual total sediment load of Clear Creek for water years 2004-07 was estimated by summing the suspendedsediment load and bedload (table 2) and was compared to the loads calculated from data for 1976-77 reported by Fisher (1978, and table 4 in this report) to evaluate whether sediment transport characteristics of the basin have changed over the last 30 years. The regression lines relating annual total sediment load to mean annual discharge have very different slopes (fig. 27), and indicate that the sediment loads for 1976 and 1977 are greater than would be predicted on the basis of data collected in the current investigation. This difference may be due, in large part, to the different methods used to collect samples and to determine mean annual discharge. Fisher directly measured the total-sediment transport rate by collecting samples from a flume whereas USGS collected individual suspended-sediment and bedload samples. USGS did not determine discharge during Fisher's study and his methods to determine daily mean stage differed from USGS methods. A comparison of the slopes of the two regression lines shown in figure 27 is problematic in that only two data points are available for the 1970s.

Table 4. Mean annual discharge and suspended- and totalsediment loads and yields for Clear Creek, Carson City and Douglas Counties, Nevada, water years 1976-77.

[Values computed from Fisher (1978, table 3). Abbreviations: ft 3 s, cubic foot per second; $\left(\mathrm{t} / \mathrm{mi}^{2}\right) / \mathrm{yr}$, ton per square mile per year; $\mathrm{t} / \mathrm{yr}$, ton per year]

\begin{tabular}{|c|c|c|c|}
\hline \multirow{2}{*}{$\begin{array}{l}\text { Water } \\
\text { year }\end{array}$} & \multirow{2}{*}{$\begin{array}{c}\text { Mean } \\
\text { annual } \\
\text { discharge } \\
\left(\mathbf{f t}^{3} / \mathbf{s}\right)\end{array}$} & \multicolumn{2}{|c|}{ Annual total sediment } \\
\hline & & $\begin{array}{l}\text { Load } \\
\text { (t/yr) }\end{array}$ & $\begin{array}{c}\text { Yield } \\
{\left[\left(\mathrm{t} / \mathrm{mi}^{2}\right) / \mathrm{yr}\right]}\end{array}$ \\
\hline 1976 & 2.9 & 1,280 & 83.2 \\
\hline 1977 & 2.0 & 1,130 & 76.8 \\
\hline
\end{tabular}




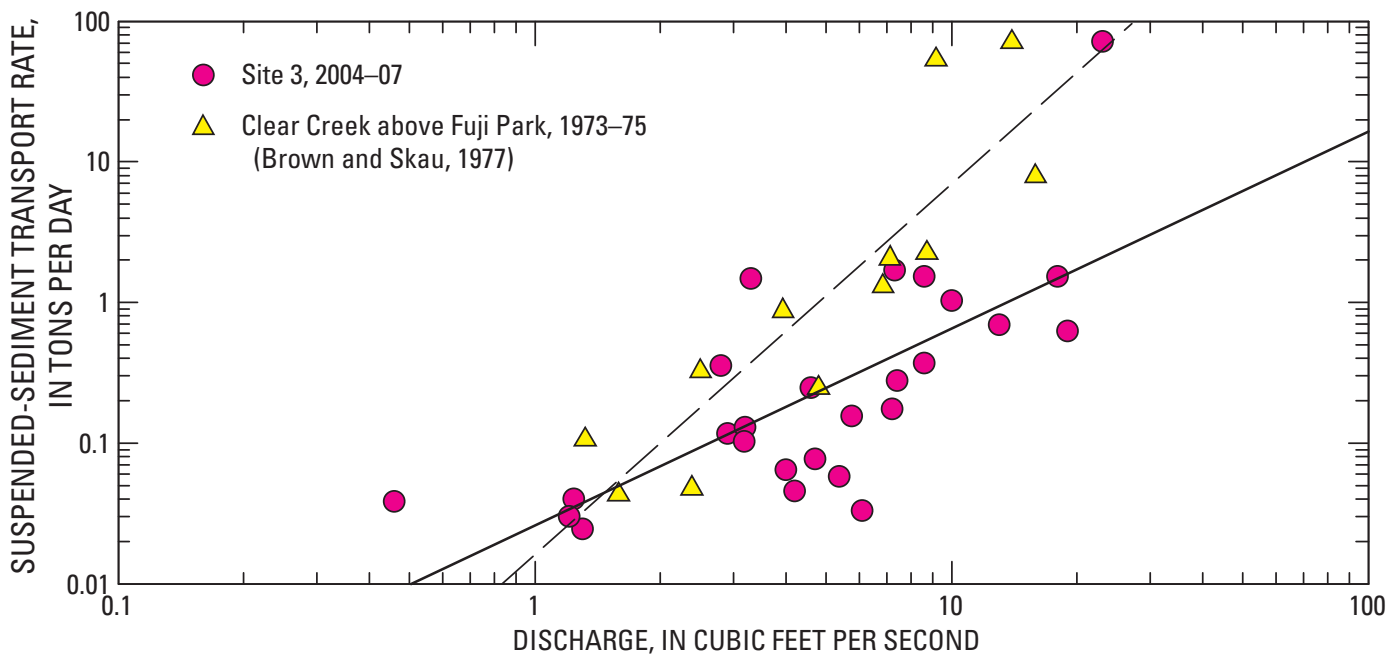

Figure 26. Relation between suspended-sediment transport rate and discharge during water years 1973-75 and 2004-07 at site 3, Clear Creek at Fuji Park, at Carson City, Douglas County, Nevada.

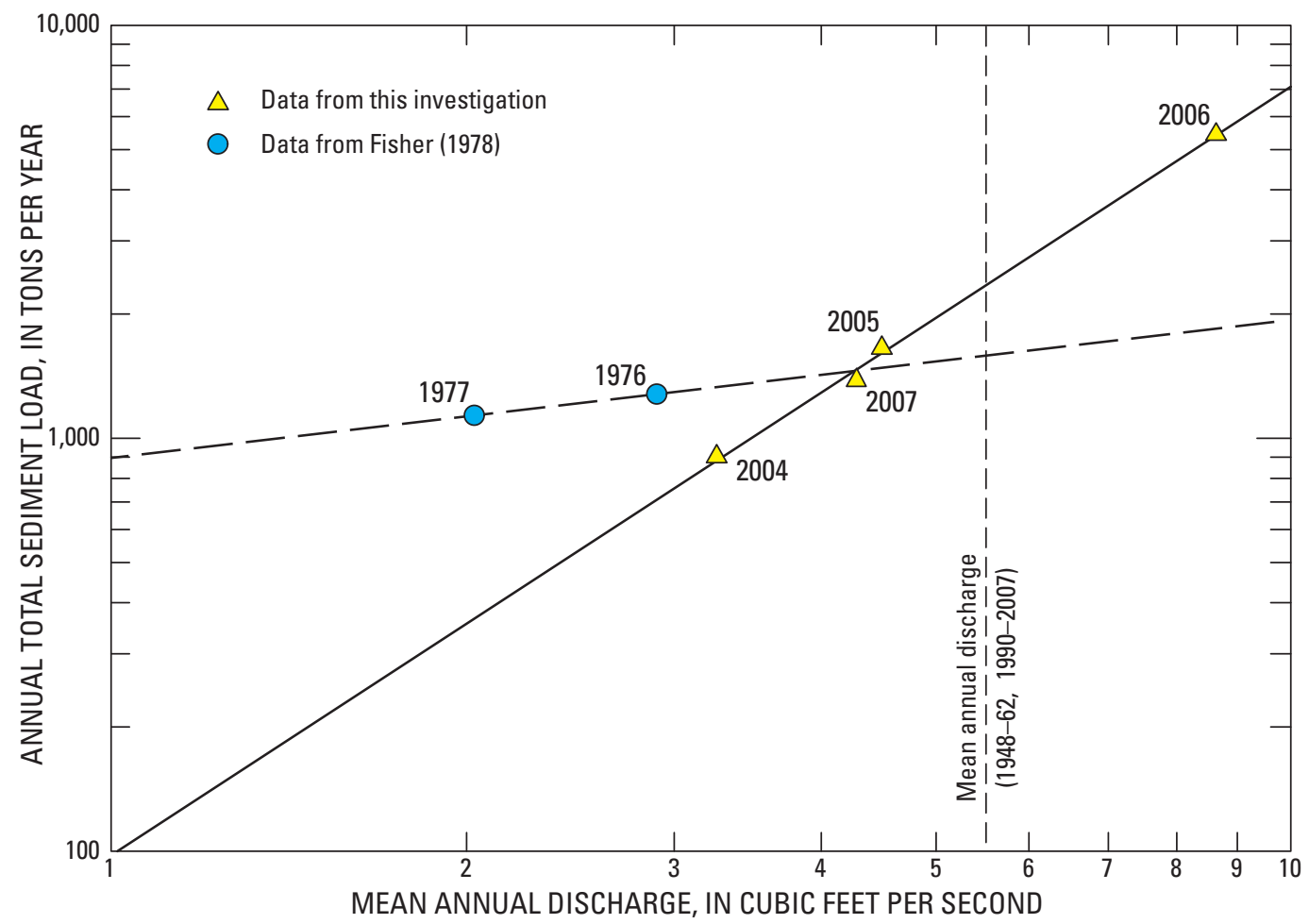

Figure 27. Relation between mean annual discharge and total sediment discharge for Clear Creek, Nevada. 


\section{Summary and Conclusions}

Clear Creek is a small stream that drains the Eastern Sierra Nevada near Lake Tahoe and ultimately discharges to the Carson River near Carson City, Nevada. The basin is mostly undeveloped, and 89 percent of the land cover is evergreen forests and shrub/scrub plant communities. The principal developed areas are the U.S. Highway 50 corridor, which roughly parallels Clear Creek through the basin, and commercial and residential areas in the lower basin near Carson City.

A previous investigation of erosion in the Clear Creek drainage basin identified areas of severe erosion, principally those associated with roadbank and gully erosion along U.S. Highway 50 and Clear Creek road. Most sediment deposition occurs in the lower basin near Fuji Park and Washoe Tribe property upstream of the park.

On the basis of analysis of samples collected at three sites along Clear Creek, water quality throughout the creek within the study area meets U.S. Environmental Protection Agency primary and secondary drinking-water standards for all measured constituents except turbidity, which exceeded the standard during periods of spring runoff and storms. Chloride concentrations increased substantially between the upper two sampling sites and were strongly seasonal, being greatest during late winter and early spring and least during baseflow in late summer. The salt used to control road icing is the likely source of the chloride in the stream during snow melt runoff.

Suspended-sediment concentrations at site 1 in the undeveloped headwaters upstream of U.S. Highway 50 ranged from 2 to 155 milligrams per liter (mg/L). At site 2, downstream of U.S. Highway 50 and low-density residential areas, suspended-sediment concentrations ranged from 3 to $468 \mathrm{mg} / \mathrm{L}$. At site 3, downstream of U.S. Highway 50, and low-density residential and commercial areas, suspendedsediment concentrations ranged from 2 to $1,150 \mathrm{mg} / \mathrm{L}$. The greatest sediment concentrations in Clear Creek occurred during storm runoff. During high flow when discharge at sites 2 and 3 are about the same, suspended-sediment transport rates tended to be lower at site 3 than site 2, suggesting that sediment deposition is occurring in this reach. This is consistent with the conclusion of an earlier investigator that most sediment deposition is occurring in the reach downstream of site 2 .

Suspended-sediment loads and yield were computed for water years 2004 through 2007 at site 2 using a simple linear regression between suspended-sediment transport rates and stream discharge. Suspended-sediment loads ranged from about 1,456 tons per year in water year 2006 to only 100 tons per year in 2007. These correspond to average sediment yields of 93.9 and 6.4 tons per square mile per year.
The seasonality of the suspended-sediment loads differed substantially over the 4 years. In water year 2006, the greatest amounts of sediment transport occurred during storm runoff in December and snowmelt runoff in May, whereas during the other years there were no large storms and the greatest amount of sediment discharge was associated with spring runoff. The suspended-sediment load on December 31, 2005, alone exceeded the combined annual load for water years 2004, 2005, and 2007. Most sediment transport occurs during high flow and demonstrates the importance of collecting samples during these flows to define the regression curves used to estimate loads.

Average sediment yield in Clear Creek was much greater than in the Logan House Creek, Edgewood Creek, and Glenbrook Creek drainage basins in the Lake Tahoe basin. The differences could be related to several factors, including differences in erosional history, the presence or absence of retention ponds and beaver dams in the drainage basins, and the path of U.S. Highway 50 through the drainage basins.

A major limitation of the study is that streamflow was below average in 3 of the 4 years of data collection. Only two samples are available for stream discharges greater than 20 cubic feet per second to define the relation between sediment transport rates and stream discharge. Samples defining the upper end of the regression curves are important because most sediment is carried during low-frequency, highdischarge events. Finally, data collected during this study are not adequate to evaluate the effects of storm runoff from commercial areas on water quality. Not all storm runoff from commercial sites near Clear Creek would be sampled at site 3 and, furthermore, sampling effort in this study during storms emphasized data collection at site 2 rather than site 3 .

Earlier investigators concluded that major erosion areas they identified in the basin during field reconnaissance in 2001-02 may not have been present during 1973-75, which suggests that sediment-transport characteristics of the basin continue to change over time. Nonetheless, the available data are insufficient to demonstrate the extent of any such changes over the last 30 years. This is due largely to the limited data collected during the 1970s and the different methods and sampling locations used in the studies. Now, however, 4 years of baseline data are available that can be used to evaluate changes in water-quality and sediment transport that occur as a result of the continued development of the basin.

Continued sediment and water-quality monitoring at the gaging station (site 2) and the background site (site 1) would provide the data needed to determine whether changes are occurring in the basin as a result of the extensive development in progress. Runoff from lawns and greens on the planned golf course may carry nutrients and pesticides into Clear Creek, and winter use of road salt in new residential areas 
may result in increases in chloride concentrations in the creek. Monitoring particularly is needed during high-flow storm and spring runoff events so that the uncertainty in estimates of suspended-sediment transport rates during high flow can be reduced. The information also could be used to assess the beneficial effects of remedial work in reducing erosion along U.S. Highway 50. Additional sampling at site 3 during high flow and storm regimes would provide data needed to determine the effects of storm runoff from commercial areas on water quality, and whether sediment deposited downstream of site 2 during normal flow regimes is being mobilized and possibly reaching the Carson River.

\section{References Cited}

Brown, J.B., and Skau, C.M., 1977, Forested watersheds of the east central Sierra Nevada-Studies of the quality of natural waters: University of Nevada (Reno) Division of Renewable Resources Report, 159 p.

Davis, B.E., 2005, A guide to the proper selection and use of federally approved sediment and water-quality samplers: U.S. Geological Survey Open-File Report 2005-1087, 35 p., accessed April 16, 2008, at http://pubs.usgs.gov/ of/2005/1087/

Davis, S.P., 1912, Ormsby County, The History of Nevada: Accessed January 17, 2008, at http://www.nevadaobserver. com/History\%20Of\%20Ormsby\%20County\%20(1912).htm

Dettinger, Michael, 2004, Fifty-two years of "Pineapple Express” storms across the west coast of North America: PIER Project Report CEC-500-2005-004, 15 p., accessed January 18, 2008 at http://www.energy. ca.gov/2005publications/CEC-500-2005-004/CEC-5002005-004.PDF

Eaton, A.D., Clesceri, L.S., and Greenberg, A.E., eds., 1995, Standard methods for the examination of water and wastewater (19th ed.): American Public Health Association, $1325 \mathrm{p}$.

Edwards, T.K., and Glysson, G.D., 1999, Field methods for measurement of fluvial sediment: U.S. Geological Survey Techniques of Water-Resources Investigations, book 3, chap. C2, 89 p.

Fisher, J.B., 1978, Flume development for a study of bedload and suspended sediment in Clear Creek Drainage, Eastern Sierra Nevada: University of Nevada, Reno, unpublished Masters thesis, $83 \mathrm{p}$.
Fishman, M.J., and Friedman, L.C., eds., 1989, Methods for determination of inorganic substances in water and fluvial sediments: U.S. Geological Survey Techniques of WaterResources Investigations, book 5, chap. A1, 545 p.

Forman, R.T.T., 2003, Road Ecology-Science and Solutions: Island Press, $424 \mathrm{p}$.

Fritchel, P.E., 2003, Evaluation of erosion control strategies used for channel protection in the Clear Creek Watershed, Eastern Sierra Nevada: University of Nevada, Reno, unpublished Masters thesis, 141 p.

Helley, E.J., and Smith, Winchell, 1971, Development and calibration of a pressure-difference bedload sampler: U.S. Geological Survey Open-File Report, 18 p.

Helsel, D.R., and Hirsch, R.M., 1992, Statistical methods in water resources: Amsterdam, The Netherlands, Elsevier Science Publishers, 529 p.

Jeton, A.E., 2006, Flood chronology of the Carson River basin, California and Nevada web site: U.S. Geological Survey Fact Sheet 2006-3102, accessed January 18, 2008, at http://nevada.usgs.gov/crfld/

Maurer, D.K., and Halford K.J., 2004, Updated estimates of the distribution of average annual precipitation in Carson Valley, 1971-2000, Douglas County, Nevada, and Alpine County, California: Journal of the Nevada Water Resources Association, v. 1, no. 1, p. 20-39.

Moore, J.G., 1969, Geology and mineral deposits of Lyon, Douglas, and Ormsby Counties, Nevada: Nevada Bureau of Mines and Geology Bulletin 75, p. 45.

National Research Council, 1947, Report of the subcommittee on sediment terminology: Transactions of the American Geophysical Union, v. 28, no. 6.

Natural Resources Conservation Service, 2006a, Soil Survey Geographic (SSURGO) Database for Carson City area, NV: accessed February 12, 2008, at http://soildatamart.nrcs.usda. gov/

Natural Resources Conservation Service, 2006b, Soil Survey Geographic (SSURGO) Database for Douglas County area, NV: accessed February 12, 2008, at http://soildatamart.nrcs. $\underline{\text { usda.gov/ }}$

Pacific Southwest Inter-Agency Committee, 1968, Factors affecting sediment yield and selection and evaluation of measures for the reduction of erosion and sediment yield: Pacific Southwest Inter-Agency Committee (PSIAC) report of the water management subcommittee, $27 \mathrm{p}$. 
PBS\&J, 2003, Clear Creek Erosion Assessment: Final Report prepared for Nevada Department of Transportation, 48 p.

Porterfield, George, 1972, Computation of fluvial-sediment discharge: U.S. Geological Survey Techniques of WaterResources Investigations, book 3, chap. C3, 66 p.

Rocha, Guy, 2005, Getting fired up: Nevada State Archives Historical Myth a Month, Myth \#117: accessed May 13, 2008, at http://nevadaculture.org/nsla/index. php?option=com content\&task=view\&id=781\& Itemid $=95$

Shelton, L.R., 1994, Field guide for collecting and processing stream-water samples for the National Water-Quality Assessment Program: U.S. Geological Survey Open-File Report 94-455, 42 p.

Stevenson, T.K., 1989, Clear Creek erosion-sedimentation evaluation, Carson-Walker Resource Conservation and Development Area: Soil Conservation Service, U.S. Department of Agriculture, 7 p.

Stewart, J.H., 1980, Geology of Nevada: Nevada Bureau of Mines and Geology Special Publication 4, 136 p.

Uhrich, M.A., and Bragg, H.M., 2003, Monitoring instream turbidity to estimate continuous suspended-sediment loads and yields and clay-water volumes in the upper North Santiam River basin, Oregon, 1998-2000: U.S. Geological Survey Water-Resources Investigations Report 03-4098, 43 p.
U.S. Census Bureau, 2008, Census 2000, Nevada: U.S. Census Bureau, accessed May 16, 2008, at http://quickfacts.census. gov/qfd/states/32000.html

U.S. Geological Survey, 2003, National Land Cover Database 2001: accessed April 5, 2007, at http://seamless.usgs.gov/

U.S. Geological Survey, 2008, Water resources data, Nevada, water year 2007: U.S. Geological Survey Water-Data Report WDR-US-2007, site 10310500, accessed May 13, 2008, at http://wdr.water.usgs.gov/

U.S. Soil Conservation Service, 1979, Soil survey of Carson City area, Nevada: U.S. Government Printing Office, 169 p.

U.S. Soil Conservation Service, 1984, Soil Survey of Douglas County area, Nevada: U.S. Government Printing Office, 575 p.

Western Regional Climate Center, 2008, Dagget Pass, Nevada (262119)_Period of record monthly climate summary: accessed May 13, 2008, at http://www.wrcc.dri.edu/cgi-bin/ cliRECtM.pl?nv2119

Wilde, F.D., and Radtke, D.B., eds., 1998, National field manual for the collection of water quality data-Field measurements: U.S. Geological Survey Techniques of Water-Resources Investigations, book 9, chap. A6, variously paginated. 


\section{Appendix 1. Streamflow, Field Measurements, and Suspended-Sediment Analyses for Samples Collected at Sites Along Clear Creek, Carson City and Douglas County, Nevada, Water Years 2004-07.}

Appendix 1. Streamflow, field measurements, and suspended-sediment analyses for samples collected at sites along Clear Creek, Carson City and Douglas County, Nevada, water years 2004-07.

[Location of sampling sites are shown in figure 1. Sand break: The sand break indicates the percent of material in the sample, by weight, that is finer than sand (0.062 mm). Abbreviations: e, estimated; NTU, nephelometer turbidity unit; $\mathrm{ft} / 3 / \mathrm{s}$, cubic foot per second; ${ }^{\circ} \mathrm{C}$, degrees Celsius; $\mathrm{mg} / \mathrm{L}, \mathrm{milligrams}$ per liter; $\mu \mathrm{S} / \mathrm{cm}$, microsiemens per centimeter at 25 degrees Celsius; t/d, tons per day; \%, percent; -, data not collected or analyzed]

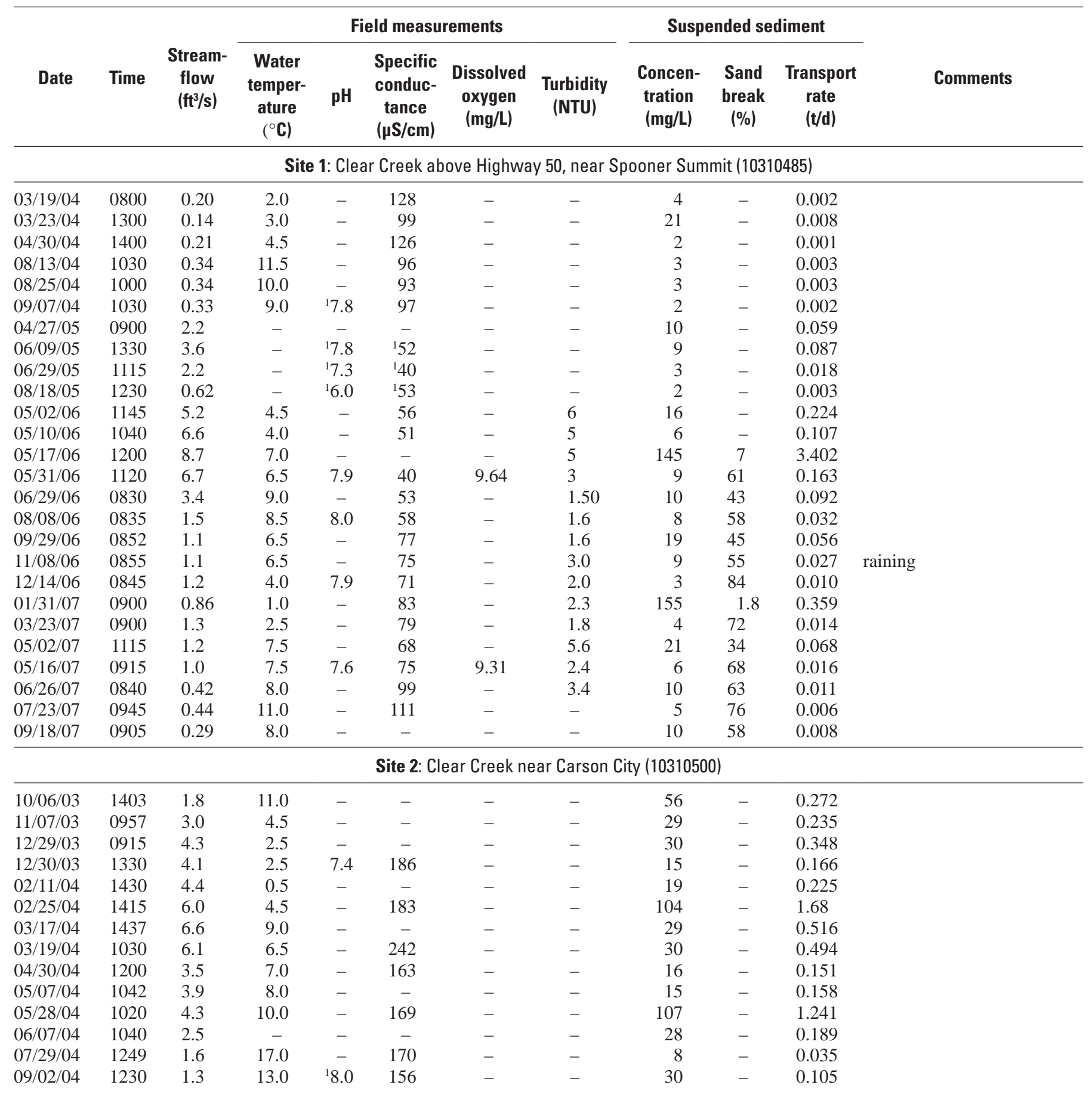


Appendix 1. Streamflow, field measurements, and suspended-sediment analyses for samples collected at sites along Clear Creek, Carson City and Douglas County, Nevada, water years 2004-07.-Continued.

[Location of sampling sites are shown in figure 1. Sand break: The sand break indicates the percent of material in the sample, by weight, that is finer than sand $(0.062 \mathrm{~mm})$. Abbreviations: e, estimated; NTU, nephelometer turbidity unit; $\mathrm{ft} / \mathrm{s}$, cubic foot per second; ${ }^{\circ} \mathrm{C}$, degrees Celsius; $\mathrm{mg} / \mathrm{L}, \mathrm{milligrams} \mathrm{per}$ liter; $\mu \mathrm{S} / \mathrm{cm}$, microsiemens per centimeter at 25 degrees Celsius; t/d, tons per day; \%, percent; -, data not collected or analyzed]

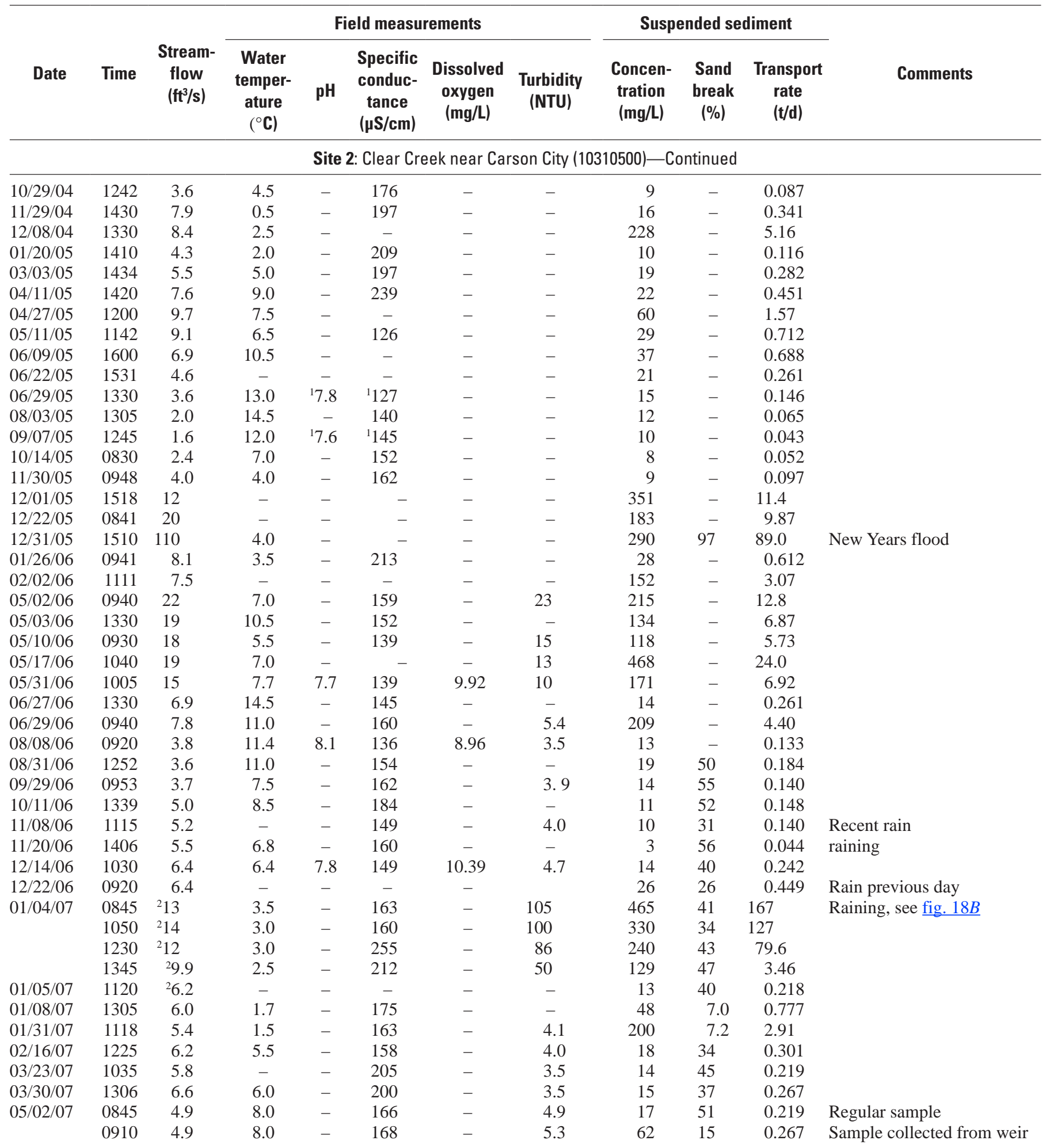


Appendix 1. Streamflow, field measurements, and suspended-sediment analyses for samples collected at sites along Clear Creek, Carson City and Douglas County, Nevada, water years 2004-07.-Continued.

[Location of sampling sites are shown in figure 1. Sand break: The sand break indicates the percent of material in the sample, by weight, that is finer than sand $(0.062 \mathrm{~mm})$. Abbreviations: e, estimated; NTU, nephelometer turbidity unit; $\mathrm{ft} / \mathrm{s}$, cubic foot per second; ${ }^{\circ} \mathrm{C}$, degrees Celsius; $\mathrm{mg} / \mathrm{L}, \mathrm{milligrams} \mathrm{per}$ liter; $\mu \mathrm{S} / \mathrm{cm}$, microsiemens per centimeter at 25 degrees Celsius; t/d, tons per day; \%, percent; -, data not collected or analyzed]

\begin{tabular}{|c|c|c|c|c|c|c|c|c|c|c|c|}
\hline Date & Time & $\begin{array}{c}\text { Stream- } \\
\text { flow } \\
\left(\mathrm{ft}^{3} / \mathrm{s}\right)\end{array}$ & \multicolumn{5}{|c|}{ Field measurements } & \multicolumn{3}{|c|}{ Suspended sediment } & Comments \\
\hline \multicolumn{12}{|c|}{ Site 2: Clear Creek near Carson City (10310500)_Continued } \\
\hline 06/26/07 & 0955 & 2.3 & 10.5 & - & 172 & - & 3.7 & 6 & 65 & 0.125 & \\
\hline 07/10/07 & 0910 & 2.2 & 15.6 & - & 154 & - & 3.9 & 13 & 71 & 0.187 & \\
\hline 07/23/07 & 1230 & 1.7 & 15.5 & 8.2 & 168 & 8.50 & 2.4 & 6 & 79 & 0.037 & \\
\hline 08/14/07 & 1040 & 1.7 & 13.9 & - & 156 & - & - & 7 & 58 & 0.077 & \\
\hline 09/18/07 & 1020 & 1.9 & 10.0 & 7.9 & 156 & - & - & 13 & 64 & 0.028 & \\
\hline 10/09/07 & 1415 & 2.9 & 8.8 & - & 152 & - & 2.6 & 7 & 69 & 0.032 & \\
\hline 03/19/04 & 0930 & 7.2 & 7.0 & - & 244 & - & - & 9 & - & 0.175 & \\
\hline 04/30/04 & 1300 & 4.0 & 10.5 & - & 168 & - & - & 6 & - & 0.065 & \\
\hline 05/28/04 & 0850 & 2.8 & 10.5 & - & 156 & - & - & 47 & - & 0.355 & \\
\hline 09/07/04 & 1300 & 0.46 & 15.5 & 27.6 & 172 & - & - & 31 & - & 0.038 & \\
\hline $12 / 08 / 04$ & 1500 & 8.6 & - & - & - & - & - & 66 & - & 1.53 & \\
\hline 04/27/05 & 1400 & 8.6 & - & - & - & - & - & 16 & - & 0.371 & \\
\hline 06/18/05 & 1045 & - & - & 27.9 & ${ }^{2} 154$ & - & - & - & - & & \\
\hline 06/29/05 & 1500 & 2.9 & - & - & - & - & - & 15 & - & 0.117 & \\
\hline 08/18/05 & 1045 & 1.3 & - & - & - & - & - & 7 & - & 0.025 & \\
\hline 05/02/06 & 0915 & 23 & 7.0 & - & 164 & - & 15 & 1,150 & - & 71.3 & \\
\hline 05/10/06 & 0830 & 19 & 5.5 & - & 143 & - & 11 & 12 & - & 0.615 & \\
\hline 05/17/06 & 1000 & 18 & 7.5 & - & - & - & 12 & 32 & 61 & 1.55 & \\
\hline 03/23/07 & 1130 & 5.76 & 5.5 & - & 208 & - & 5.2 & 10 & 82.8 & 0.155 & \\
\hline 05/02/07 & 1015 & 4.59 & 10.0 & - & 172 & - & 7.4 & 20 & 65.0 & 0.248 & \\
\hline 05/16/07 & 1135 & 3.18 & 12.9 & 7.7 & 182 & 8.38 & 7.8 & 12 & 86.1 & 0.103 & \\
\hline 06/26/07 & 1115 & 1.24 & - & - & 176 & - & 4.2 & 12 & 66.7 & 0.040 & \\
\hline 07/23/07 & 1041 & 1.21 & 16.0 & - & 185 & - & - & 10 & 72.6 & 0.033 & \\
\hline 09/18/07 & 1004 & 1.32 & 10.5 & - & - & - & - & 11 & 84.7 & 0.039 & \\
\hline
\end{tabular}

${ }^{1}$ Laboratory measurement.

${ }^{2}$ Discharge determined from recorded gage height and rating curve.

${ }^{3}$ Discharge estimated from streamflow at site 2. 
This page intentionally left blank. 


\section{Appendix 2. Bedload-Sediment Data for Samples Collected at Site 2, Clear Creek near Carson City (10310500), Douglas County, Nevada, Water Years 2004-07.}

Appendix 2. Bedload-sediment data for samples collected at site 2, Clear Creek near Carson City (10310500), Douglas County, Nevada, water years 2004-07.

[Grain-size classification from National Research Council (1947). Abbreviations: mm, millimeter; $\mathrm{ft}^{3} / \mathrm{s}$, cubic foot per second; $\mathrm{t} / \mathrm{d}$, tons per day; E, environmental; R, replicate; <, less than]

\begin{tabular}{|c|c|c|c|c|c|c|c|c|c|c|c|}
\hline \multirow{2}{*}{ Date } & \multirow{2}{*}{ Time } & \multirow{2}{*}{ Type } & \multicolumn{2}{|c|}{ Discharge } & \multicolumn{7}{|c|}{ Bedload-sediment grain-size (in mm) classification, weight percent } \\
\hline & & & $\begin{array}{c}\text { Streamflow } \\
\left(\mathrm{ft}^{3} / \mathbf{s}\right)\end{array}$ & $\begin{array}{l}\text { Bedload } \\
\text { sediment } \\
(t / d)\end{array}$ & $\begin{array}{c}\text { Clay and } \\
\text { silt } \\
<0.063\end{array}$ & $\begin{array}{c}\text { Very fine } \\
0.063-0.125\end{array}$ & $\begin{array}{c}\text { Fine } \\
0.125-0.25\end{array}$ & $\begin{array}{l}\text { Medium } \\
0.25-0.5\end{array}$ & $\begin{array}{l}\text { Coarse } \\
0.5-1.0\end{array}$ & $\begin{array}{c}\text { Very } \\
\text { coarse } \\
1-2\end{array}$ & $\begin{array}{r}\text { Grave } \\
2-16\end{array}$ \\
\hline $02 / 25 / 04$ & 1415 & $\mathrm{E}$ & 6.0 & 7.3 & 0.0 & 0.2 & 2.2 & 28.7 & 34.6 & 23.3 & 11.0 \\
\hline 09/02/04 & 1200 & $\mathrm{E}$ & 1.3 & 0.38 & 0.0 & 0.2 & 1.8 & 15.7 & 34.1 & 31.6 & 16.6 \\
\hline $12 / 08 / 04$ & 1430 & $\mathrm{E}$ & 8.4 & 9.4 & 0.1 & 0.1 & 2.5 & 24.9 & 30.2 & 20.2 & 22.0 \\
\hline 04/27/05 & 1320 & $\mathrm{E}$ & 9.7 & 6.8 & 0.0 & 0.2 & 3.3 & 27.3 & 36.3 & 22.7 & 10.2 \\
\hline 06/09/05 & 1600 & $\mathrm{E}$ & 6.9 & 8.2 & 0.1 & 0.0 & 0.7 & 8.3 & 30.2 & 34.8 & 25.9 \\
\hline $11 / 03 / 06$ & 0830 & $\mathrm{E}$ & 5.0 & 0.82 & 0.1 & 0.0 & 2.3 & 27.2 & 32.1 & 23.8 & 14.5 \\
\hline $01 / 04 / 07$ & 0845 & $\mathrm{E}$ & 13 & 16 & 0.0 & 0.2 & 2.7 & 19.4 & 32.5 & 30.2 & 15.0 \\
\hline
\end{tabular}


This page intentionally left blank. 


\section{Appendix 3. Water-Quality Data for Samples Collected at Sites Along Clear Creek, Carson City and Douglas County, Nevada, Water Years 2004-07.}

Appendix 3. Water-quality data for samples collected at sites along Clear Creek, Carson City and Douglas County, Nevada, water years 2004-07.

[Location of sampling sites are shown in figure 1. Field values for samples are presented in appendix 1. Water samples are filtered through a $0.45 \mu \mathrm{M}$ capsule filter, except as noted. Dissolved solids: Dissolved solids was determined as the Sum of Constituents, which is calculated as the sum of the calcium, magnesium, sodium, potassium, chloride, fluoride, sulfate, silica concentrations, plus 0.60 times the alkalinity as $\mathrm{CaCO}_{3}$. It is a substitute for measurements of Total Dissolved Solids using residue on evaporation at 180 degrees Celsius. Kjeldahl nitrogen and Kjeldahl nitrogen, unfiltered sample: Kjeldahl nitrogen is ammonia plus organic nitrogen. Abbreviations: mg/L, milligram per liter; $\mu \mathrm{g} / \mathrm{L}$, microgram per liter; $\mu \mathrm{M}$, micrometer; E, estimated; <, less than]

\begin{tabular}{|c|c|c|c|c|c|c|c|c|c|c|c|c|c|}
\hline Date & Time & $\begin{array}{c}\text { Calcium } \\
\text { as Ca } \\
\text { (mg/L) }\end{array}$ & $\begin{array}{c}\text { Mag- } \\
\text { nesium } \\
\text { (mg/L } \\
\text { as Mg) }\end{array}$ & $\begin{array}{c}\text { Sodium } \\
\text { (mg/L } \\
\text { as Na) }\end{array}$ & $\begin{array}{c}\text { Potas- } \\
\text { sium } \\
\text { (mg/L } \\
\text { as K) }\end{array}$ & $\begin{array}{c}\text { Alkalinity } \\
\text { (mg/L as } \\
\mathrm{CaCO}_{3} \text { ) }\end{array}$ & $\begin{array}{c}\text { Chloride } \\
\text { (mg/L } \\
\text { as CI) }\end{array}$ & $\begin{array}{c}\text { Fluoride } \\
\text { (mg/L } \\
\text { as F) }\end{array}$ & $\begin{array}{c}\text { Sulfate } \\
(\mathrm{mg} / \mathrm{L} \\
\left.\text { as } \mathrm{SO}_{4}\right)\end{array}$ & $\begin{array}{l}\text { Silica } \\
\text { (mg/L } \\
\text { as Si) }\end{array}$ & $\begin{array}{c}\text { Dissolved } \\
\text { solids } \\
\text { (mg/L) }\end{array}$ & $\begin{array}{c}\text { Iron } \\
\text { ( } \mu \mathrm{g} / \mathrm{L} \\
\text { as Fe) }\end{array}$ & $\begin{array}{c}\text { Man- } \\
\text { ganese } \\
(\mu \mathrm{g} / \mathrm{L} \\
\text { as } \mathrm{Mn})\end{array}$ \\
\hline \multicolumn{14}{|c|}{ Site 1: Clear Creek above Highway 50, near Spooner Summit (10310485) } \\
\hline 09/07/04 & 1030 & 10.3 & 2.23 & 5.98 & 1.51 & 150 & 0.34 & $<0.17$ & 0.30 & 23.6 & 74 & 63 & 2.0 \\
\hline 06/09/05 & 1230 & 5.39 & 1.06 & 3.83 & 0.74 & ${ }^{1} 29$ & $0.15 \mathrm{E}$ & $<0.10$ & 0.28 & 22.0 & 51 & 102 & 1.9 \\
\hline 06/29/05 & 1115 & 3.87 & 0.84 & 3.32 & 0.84 & ${ }^{1} 23$ & $0.16 \mathrm{E}$ & $<0.10$ & 0.28 & 19.2 & 42 & 72 & 1.6 \\
\hline 08/18/05 & 1230 & 5.46 & 1.07 & 3.88 & 0.74 & ${ }^{128}$ & $0.15 \mathrm{E}$ & $<0.10$ & 0.29 & 21.6 & 50 & 106 & 2.0 \\
\hline 05/31/06 & 1120 & 3.96 & 0.92 & 3.15 & 0.94 & 21 & $0.17 \mathrm{E}$ & $<0.10$ & 0.29 & 16.8 & 39 & 73 & 2.9 \\
\hline 05/16/07 & 0915 & 8.21 & 1.87 & 5.13 & 1.50 & 41 & 0.34 & $0.05 \mathrm{E}$ & 0.34 & 23.0 & 65 & 124 & 4.9 \\
\hline \multicolumn{14}{|c|}{ Site 2: Clear Creek near Carson City (10310500) } \\
\hline $12 / 30 / 03$ & 1330 & 17.8 & 3.35 & 16.9 & 2.11 & ${ }^{1} 64$ & 23.9 & $<0.2$ & 1.1 & 21.5 & 125 & 85 & 10.1 \\
\hline $09 / 02 / 04$ & 1230 & 22.3 & 3.25 & 9.68 & 2.44 & ${ }^{1} 80$ & 5.01 & $<0.2$ & 0.8 & 21.1 & 113 & 104 & 10.1 \\
\hline 06/29/05 & 1330 & 14.8 & 2.64 & 9.33 & 1.79 & ${ }^{1} 56$ & 9.71 & $0.06 \mathrm{E}$ & 0.74 & 22.0 & 95 & 186 & 10.3 \\
\hline 09/07/05 & 1245 & 19.5 & 2.78 & 8.00 & 1.79 & 170 & 5.59 & 0.11 & 0.90 & 21.6 & 102 & 150 & 11.8 \\
\hline 05/31/06 & 1005 & 12.4 & 2.52 & 10.8 & 1.80 & 46 & 13.5 & $0.08 \mathrm{E}$ & 0.65 & 20.5 & 90 & 166 & 13.2 \\
\hline 08/08/06 & 0920 & 17.7 & 2.98 & 9.97 & 2.00 & 66 & 8.48 & $0.07 \mathrm{E}$ & 0.82 & 23.4 & 105 & 232 & 10.2 \\
\hline $12 / 14 / 06$ & 1030 & 16.5 & 3.10 & 10.2 & 1.98 & 64 & 10.6 & $0.09 \mathrm{E}$ & 0.93 & 23.0 & 105 & 88 & 7.3 \\
\hline 05/16/07 & 1035 & 18.3 & 3.38 & 11.6 & 2.16 & 69 & 13.3 & $0.07 \mathrm{E}$ & 0.88 & 23.4 & 115 & 129 & 10.7 \\
\hline 07/23/07 & 1230 & 18.9 & 2.99 & 9.01 & 1.87 & 76 & 5.71 & $0.09 \mathrm{E}$ & 0.92 & 21.3 & 107 & 242 & 11.3 \\
\hline $09 / 18 / 07$ & 1020 & 19.0 & 2.99 & 8.83 & 1.92 & 77 & 4.90 & 0.10 & 0.80 & 22.0 & 107 & 72 & 10.6 \\
\hline \multicolumn{14}{|c|}{ Site 3: Clear Creek at Fuji Park, at Carson City (10310515) } \\
\hline 09/07/04 & 1300 & 21.1 & 3.36 & 10.3 & 2.50 & ${ }^{1} 82$ & 5.57 & $<0.17$ & 0.43 & 22.1 & 114 & 11 & 2.7 \\
\hline 06/18/05 & 1045 & 18.1 & 2.89 & 9.01 & 1.91 & 173 & 6.12 & $0.08 \mathrm{E}$ & 0.79 & 23.2 & 106 & 30 & 7.5 \\
\hline 06/29/05 & 1500 & 15.5 & 2.77 & 9.67 & 1.82 & ${ }^{1} 58$ & 10.0 & $0.07 \mathrm{E}$ & 0.72 & 22.5 & 98 & 212 & 12.3 \\
\hline 05/31/06 & 0915 & 12.7 & 2.56 & 10.8 & 1.83 & 48 & 13.5 & $0.07 \mathrm{E}$ & 0.63 & 21.4 & 93 & 243 & 33 \\
\hline 05/16/07 & 1135 & 18.8 & 3.48 & 11.9 & 2.17 & 71 & 13.6 & $0.07 \mathrm{E}$ & 0.80 & 23.9 & 118 & 272 & 29 \\
\hline
\end{tabular}


Appendix 3. Water-quality data for samples collected at sites along Clear Creek, Carson City and Douglas County, Nevada, water years 2004-07.-Continued.

[Location of sampling sites are shown in figure 1. Field values for samples are presented in appendix 1 . Water samples are filtered through a $0.45 \mu \mathrm{M}$ capsule filter, except as noted. Dissolved solids: Dissolved solids was determined as the Sum of Constituents, which is calculated as the sum of the calcium, magnesium, sodium, potassium, chloride, fluoride, sulfate, silica concentrations, plus 0.60 times the alkalinity as $\mathrm{CaCO}_{3}$. It is a substitute for measurements of Total Dissolved Solids using residue on evaporation at 180 degrees Celsius. Kjeldahl nitrogen and Kjeldahl nitrogen, unfiltered sample: Kjeldahl nitrogen is ammonia plus organic nitrogen. Abbreviations: $\mathrm{mg} / \mathrm{L}$, milligram per liter; $\mu \mathrm{g} / \mathrm{L}$, microgram per liter; $\mu \mathrm{M}$, micrometer; E, estimated; <, less than]

\begin{tabular}{|c|c|c|c|c|c|c|c|c|c|}
\hline Date & Time & $\begin{array}{c}\text { Kjeldahl } \\
\text { nitrogen } \\
\text { (mg/L) }\end{array}$ & $\begin{array}{l}\text { Kjeldahl nitrogen, } \\
\text { unfiltered sample } \\
\text { (mg/L) }\end{array}$ & $\begin{array}{c}\text { Ammonia } \\
\left(\mathrm{mg} / \mathrm{L} \text { as } \mathrm{NH}_{3}\right)\end{array}$ & $\begin{array}{l}\text { Nitrite plus } \\
\text { nitrate } \\
\text { (mg/L as N) }\end{array}$ & $\begin{array}{c}\text { Nitrite } \\
\text { (mg/L as N) }\end{array}$ & $\begin{array}{l}\text { Phosphorus } \\
\text { (mg/L as P) }\end{array}$ & $\begin{array}{c}\text { Phosphorus, } \\
\text { unfiltered sample } \\
(\mathrm{mg} / \mathrm{L} \text { as } \mathrm{P})\end{array}$ & $\begin{array}{l}\text { Orthophosphate } \\
\left.\text { (mg/L as } \mathrm{PO}_{4}\right)\end{array}$ \\
\hline \multicolumn{10}{|c|}{ Site 1: Clear Creek above Highway 50, near Spooner Summit (10310485) } \\
\hline 09/07/04 & 1030 & $0.06 \mathrm{E}$ & 0.11 & $0.007 \mathrm{E}$ & $<0.016$ & $<0.002$ & 0.012 & 0.021 & 0.008 \\
\hline 06/09/05 & 1230 & $0.05 \mathrm{E}$ & 0.16 & $<0.01$ & $<0.016$ & $<0.002$ & 0.012 & 0.014 & $0.005 \mathrm{E}$ \\
\hline 06/29/05 & 1230 & 0.15 & 0.17 & $0.007 \mathrm{E}$ & $<0.016$ & $0.001 \mathrm{E}$ & 0.011 & 0.015 & 0.008 \\
\hline 08/18/05 & 1230 & $0.07 \mathrm{E}$ & 0.14 & $<0.01$ & $<0.016$ & 0.002 & 0.011 & 0.019 & 0.007 \\
\hline 05/31/06 & 1120 & 0.14 & 0.20 & 0.01 & $<0.016$ & $<0.002$ & 0.010 & 0.088 & 0.013 \\
\hline 05/16/07 & 0915 & 0.18 & 0.12 & $<0.02$ & $<0.016$ & $<0.002$ & 0.011 & 0.024 & 0.013 \\
\hline \multicolumn{10}{|c|}{ Site 2: Clear Creek near Carson City (10310500) } \\
\hline $12 / 30 / 03$ & 1330 & 0.08 & 0.17 & $0.008 \mathrm{E}$ & 0.023 & 0.001 & 0.04 & 0.015 & 0.04 \\
\hline 09/02/04 & 1230 & 0.07 & 0.18 & 0.01 & 0.008 & 0.001 & 0.042 & 0.017 & 0.04 \\
\hline 06/29/05 & 1330 & 0.12 & 0.22 & $<0.01$ & $0.011 \mathrm{E}$ & $<0.002$ & 0.021 & 0.052 & 0.014 \\
\hline 09/07/05 & 1245 & $0.06 \mathrm{E}$ & 0.12 & $<0.01$ & $0.012 \mathrm{E}$ & $<0.002$ & 0.016 & 0.043 & 0.014 \\
\hline 05/31/06 & 1005 & 0.16 & 0.21 & $0.006 \mathrm{E}$ & $0.012 \mathrm{E}$ & $<0.002$ & 0.018 & 0.066 & 0.021 \\
\hline 08/08/06 & 0920 & $0.07 \mathrm{E}$ & 0.14 & $0.005 \mathrm{E}$ & 0.016 & $<0.002$ & 0.020 & 0.036 & 0.026 \\
\hline $12 / 14 / 06$ & 1030 & 0.17 & 0.10 & $<0.02$ & $0.011 \mathrm{E}$ & $<0.002$ & 0.014 & $<0.02$ & 0.013 \\
\hline 05/16/07 & 1035 & 0.17 & 0.21 & $<0.02$ & $0.011 \mathrm{E}$ & $<0.002$ & 0.015 & 0.06 & 0.017 \\
\hline 07/23/07 & 1230 & $0.06 \mathrm{E}$ & 0.11 & $<0.02$ & $0.009 \mathrm{E}$ & $<0.002$ & 0.019 & 0.03 & 0.019 \\
\hline$\underline{09 / 18 / 07}$ & 1020 & 0.11 & 0.11 & $0.014 \mathrm{E}$ & $0.010 \mathrm{E}$ & $<0.002$ & 0.013 & 0.04 & 0.016 \\
\hline \multicolumn{10}{|c|}{ Site 3: Clear Creek at Fuji Park, at Carson City (10310518) } \\
\hline 09/07/04 & 1300 & $0.09 \mathrm{E}$ & 0.22 & $0.009 \mathrm{E}$ & $0.012 \mathrm{E}$ & $0.001 \mathrm{E}$ & 0.014 & 0.054 & 0.012 \\
\hline 06/18/05 & 1045 & 0.10 & 0.14 & $0.005 \mathrm{E}$ & 0.018 & $0.001 \mathrm{E}$ & 0.020 & 0.040 & 0.011 \\
\hline 06/29/05 & 1500 & 0.14 & 0.19 & $0.005 \mathrm{E}$ & 0.017 & $0.001 \mathrm{E}$ & 0.022 & 0.053 & 0.015 \\
\hline 05/31/06 & 0915 & 0.16 & 0.30 & $0.008 \mathrm{E}$ & $0.013 \mathrm{E}$ & $<0.002$ & 0.023 & 0.026 & 0.024 \\
\hline 05/16/07 & 1135 & 0.16 & 0.25 & $<0.02$ & 0.020 & $<0.002$ & 0.024 & 0.058 & 0.024 \\
\hline
\end{tabular}

\footnotetext{
${ }^{1}$ Determined using unfiltered water and is more properly considered acid neutralizing capacity (ANC) instead of alkalinity.
} 
For more information concerning the research in this report, contact the Director, Nevada Water Science Center

U.S. Geological Survey

2730 N. Deer Run Road

Carson City, Nevada 89701

http://nevada.usgs.gov/water/ 
$\frac{1}{0}$

욤

蛋 